\title{
EVALUATION OF AGRICULTURAL BEST-MANAGEMENT PRACTICES IN THE CONESTOGA RIVER HEADWATERS, PENNSYLVANIA: Description and Water Quality of the Little Conestoga Creek Headwaters Prior to the Implementation of Nutrient Management
}

\section{WATER-QUALITY STUDY OF THE CONESTOGA RIVER HEADWATERS, PENNSYLVANIA}

By

David K. Fishel, U.S. Geological Survey

Mary Jo Brown, Pennsylvania Department of Environmental Resources

Kevin M. Kostelnik, U.S. Geological Survey

Mary A. Howse, U.S. Geological Survey

U.S. GEOLOGICAL SURVEY

Water-Resources Investigations Report 90-4131

Prepared in cooperation with the

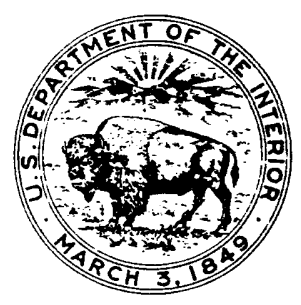

PENNSYLVANIA DEPARTMENT OF ENVIRONMENTAL RESOURCES

Lemoyne, Pennsylvania

1992 


\section{U.S. DEPARTMENT OF THE INTERIOR}

MANUEL LUJAN, JR., Secretary

\section{U.S. GEOLOGICAL SURVEY}

Dallas L. Peck, Director

For additional information

write to:

District Chief

U.S. Geological Survey, WRD

840 Market Street

Lemoyne, Pennsylvania 17043-1586
Copies of this report can be purchased from:

U.S. Geological Survey Books and Open-File Reports Section Federal Center

Box 25425

Denver, Colorado 80225 
Abstract.

Introduction

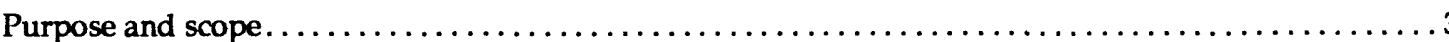

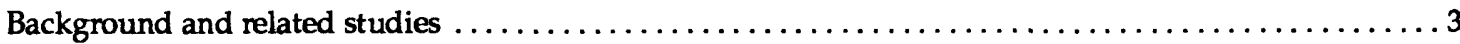

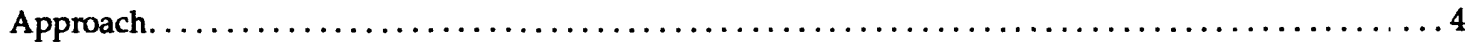

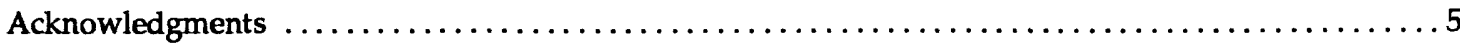

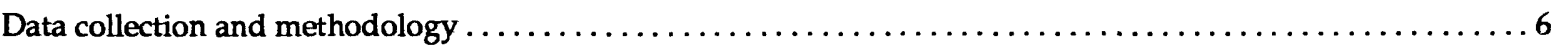

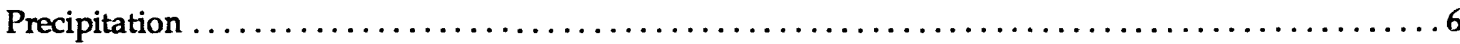

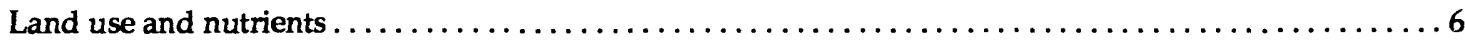

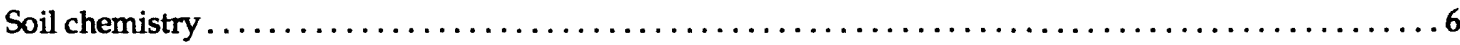

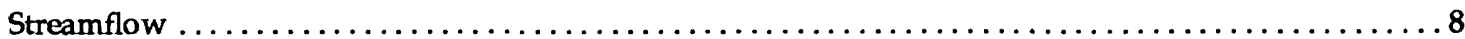

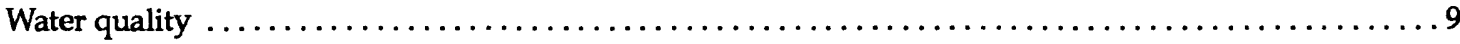

Estimating reductions in agricultural contaminants required

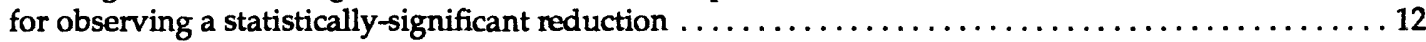

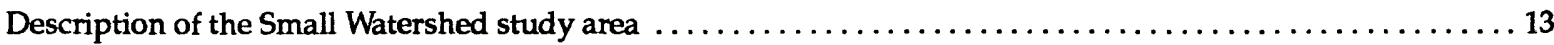

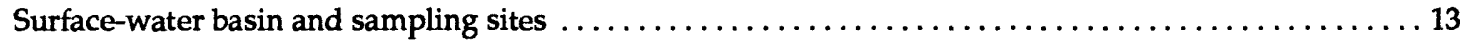

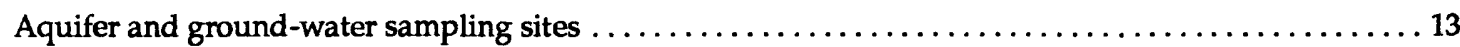

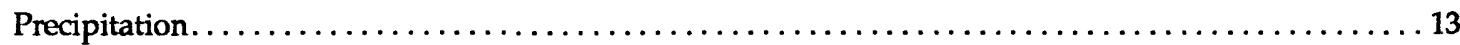

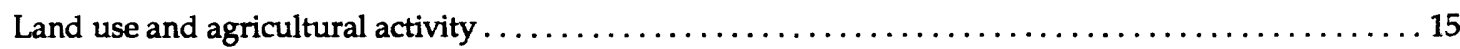

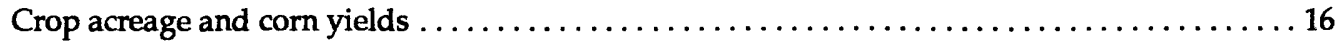

Animal population and density, and manure production $\ldots \ldots \ldots \ldots \ldots \ldots \ldots \ldots \ldots \ldots$

Nutrient applications and manure export. . . . . . . . . . . . 18

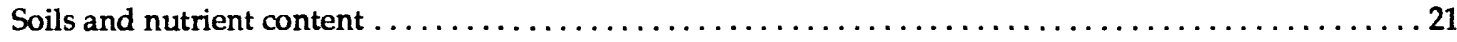

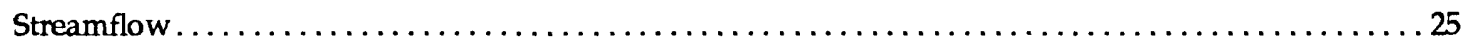

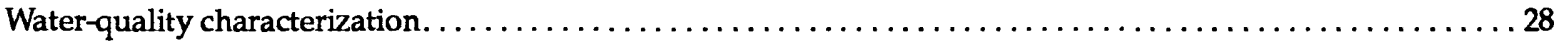

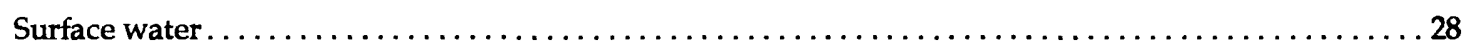

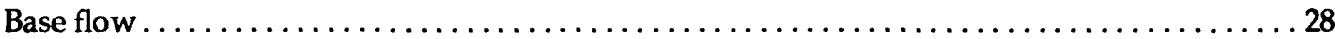

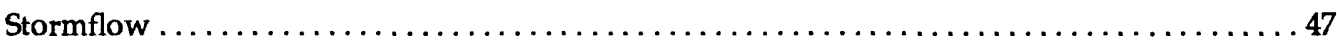

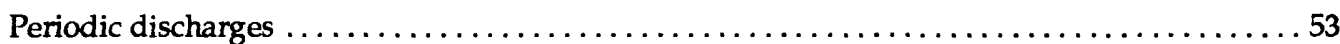

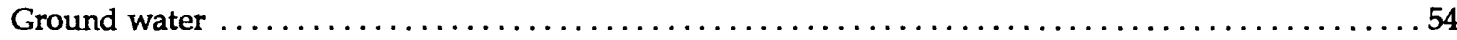

Estimates of reductions in agricultural contaminants required

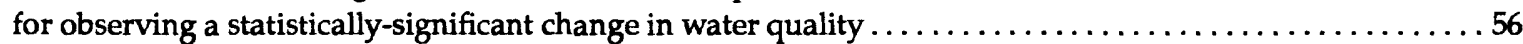

Hypothetical effects of reductions in nutrient applications on improvement

in water quality and effect of land-use changes and random events on

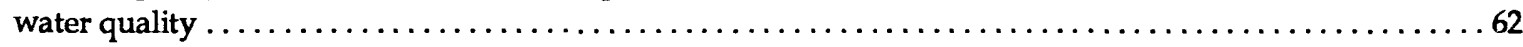

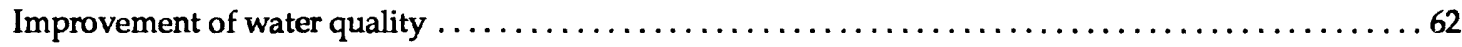

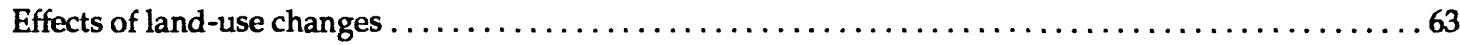

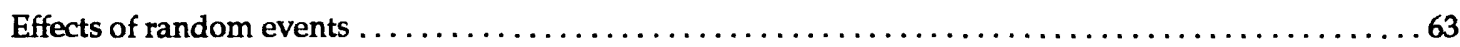

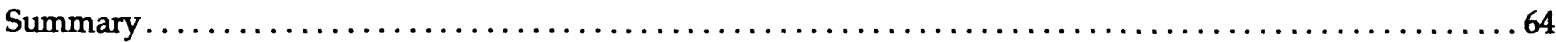

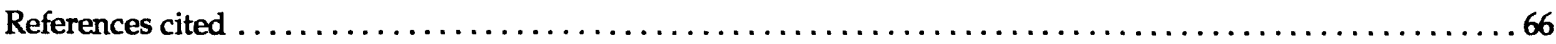


Figures 1-3.-Maps showing:

1.-Location of the Small Watershed in relation to the Regional Study Area $\ldots \ldots \ldots \ldots \ldots \ldots 2$

2.-Small Watershed data-collection locations and general geology $\ldots \ldots \ldots \ldots \ldots \ldots \ldots \ldots$

3.-Farms and soil sampling sites in the Nutrient-Management Subbasin $\ldots \ldots \ldots \ldots \ldots \ldots \ldots 7$

4-9.-Graphs showing:

4.-Monthly precipitation at the Small Watershed and normal monthly precipitation at Morgantown .

5.-Nutrient applications as reported by farmers in the Nutrient-Management Subbasin during the pre-Best-Management Practice phase, April 1, 1984, through March 31, 1986 . . 19

6.-Residual nitrate-nitrogen in the top four feet of soil after the 1984 and 1985 growing seasons (November 3, 1984, and October 9, 1985) at seven farms in the Nutrient-Management Subbasin.

7.-Residual soluble phosphorus in the top four feet of soil after the 1984 and 1985 growing seasons (November 3, 1984, and October 9, 1985) at seven farms in the

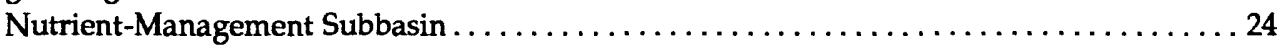

8.-Surface runoff and baseflow components of total streamflow at the NutrientManagement Subbasin and the Small Watershed, April 1, 1984, through March 31, 1986 . . 26

9.-Concentrations of dissolved nitrite plus nitrate as nitrogen and total phosphorus as phosphorus at surface-water sites during pre-Best-Management Practice phase, April 1, 1984, through March 31, 1986

10-17.-Graphs showing:

10.-Loads of dissolved nitrite plus nitrate as nitrogen and total phosphorus as phosphorus at surface-water sites during pre-Best-Management Practice phase, April 1, 1984, through March 31, 1986

11.-Precipitation in the Small Watershed and concentrations of total nitrogen, and dissolved nitrite plus nitrate as nitrogen, and total and dissolved phosphorus as phosphorus in base flow at Site 1, April 1, 1984, through March 31, 1986

12.-Base flow and loads of total nitrogen, and dissolved nitrite plus nitrate as nitrogen, and total and dissolved phosphorus, as phosphorus at Site 1, April 1, 1984,

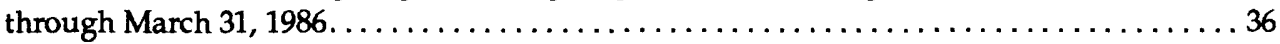

13.-Precipitation in the Small Watershed, nitrogen applications, and concentrations of total nitrogen, and dissolved nitrite plus nitrate as nitrogen in base flow at Site 3A,

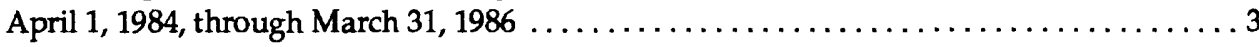

14.-Precipitation in the Small Watershed, phosphorus applications, and concentrations of total and dissolved phosphorus as phosphorus in base flow at Site 3A, April 1, 1984, through March 31, 1986.

15.-Loads of total nitrogen and dissolved nitrite plus nitrate as nitrogen, and total and dissolved phosphorus as phosphorus in base flow at Site 3A, April 1, 1984,

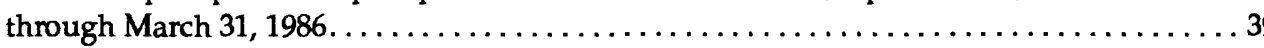

16.-Precipitation in the Small Watershed and concentrations of total nitrogen and dissolved nitrite plus nitrate as nitrogen, and total and dissolved phosphorus as phosphorus in base flow at Site 5, April 1, 1984, through March 31, 1986 
Figures 10-17.-Graphs showing-Continued

17.--Loads of total nitrogen and dissolved nitrite plus nitrate as nitrogen, and total and dissolved phosphorus as phosphorus in base flow at Site 5, April 1, 1984, through March 31, 1986

18-24.-Graphs showing:

18.--Relation of concentrations of dissolved nitrite plus nitrate as nitrogen and total phosphorus as phosphorus between the Paired-Watersheds

19.--Relation of loads of dissolved nitrite plus nitrate as nitrogen and total phosphorus as phosphorus between the Paired-Watersheds

20.-Streamflow and concentrations of suspended sediment, total-nitrogen constituents, and total phosphorus at the Nutrient-Management Subbasin during the storm of

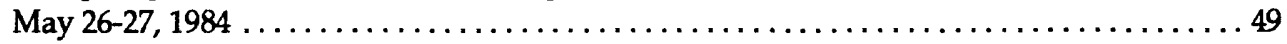

21.-Streamflow and concentrations of suspended sediment, total-nitrogen constituents, and total phosphorus at the Small Watershed during the storm of May 26-27, 1984 . .

22-Dissolved-nitrate as nitrogen concentrations in ground water in the NutrientManagement Subbasin, April 1, 1984, through March 31, 1986.

23.-Probability of achieving statistically significant changes at selected reductions in total-nitrogen and dissolved-nitrite plus nitrate as nitrogen concentrations and loads in base flow.

24.-Probability of achieving statistically significant changes at selected reductions in total- and dissolved-phosphorus concentrations and loads in base flow 
Table 1.-Description of surface-water stations in the Small Watershed and at Lancaster . . . . . . . . . 8

2.-Water-quality characteristics measured and sampling frequencies

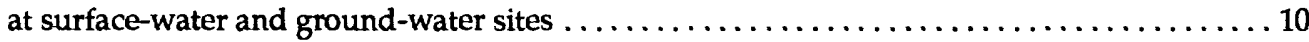

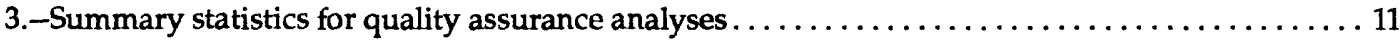

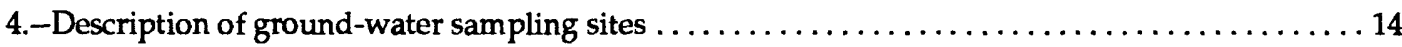

5.-Land use and crop acreage in the Nutrient-Management Subbasin,

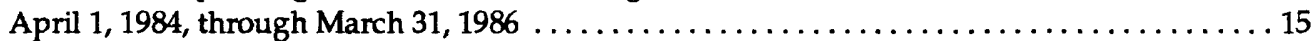

6.-Average corn yields at farms in the Nutrient-Management Subbasin,

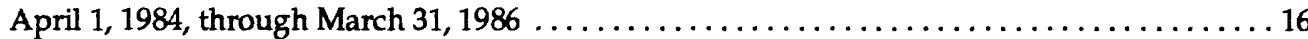

7.-Animal types and manure production in the Nutrient-Management Subbasin

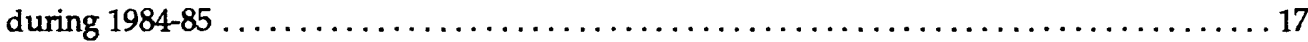

8.-Animal densities of farms in the Nutrient-Management Subbasin based on total crop

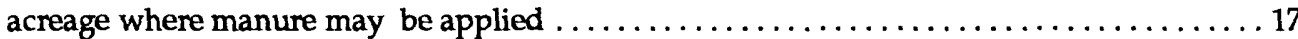

9.-Manure production and nutrient content of manure by animal type $\ldots \ldots \ldots \ldots \ldots \ldots \ldots \ldots$

10.-Amounts of manure and commercial fertilizer spread on fields in the Nutrient-Management Subbasin, April 1, 1984, through March 31, 1986 . . . . . . . 20

11.-Total streamflow and base-flow contributions at the Small Watershed and the NutrientManagement Subbasin during the pre-Best-Management Practice phase, April 1, 1984,

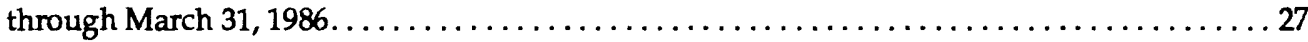

12.-Water-quality characteristics of base flow in the Small Watershed, April 1,1984, through March 31, 1986 (pre-Best-Management Practice period data) .

13a.-Monthly and annual nutrient and suspended-sediment loads in base flow at the Nutrient-Management Subbasin (Site 3A) during the pre-Best-Management Practice phase, April 1, 1984, through March 31, 1986

13b.-Monthly and annual nutrient and suspended-sediment loads in base flow at the Small Watershed (Site 5) during the pre-Best-Management Practice phase, April 1, 1984, through March 31, 1986

14.-Concentrations of total atrazine and total simazine in base flow at Site 1 prior to and following the identification of the disposal area, May 10, 1984, through November 20, 1985 . 46

15.--Ranges of instantaneous storm concentrations from April 1,1984, through March 31, 1986 ... 48

16.-Nitrogen, phosphorus, and suspended-sediment loads during storm days at the Nutrient-Management Subbasin (Site 3A) and the Small Watershed (Site 5), April 4, 1984, through March 15, 1986

17.-Nutrient concentrations in base flow in the Small Watershed during times of periodic point-source discharges, October 24, 1984, through March 13, 1986......... 53

18.-Summary statistics of ground-water quality for the Nutrient-Management Subbasin........ 54

19.-Water-quality characteristics of base flow during the study period, nongrowing seasons, and growing seasons, and estimated reductions in agricultural contaminants required

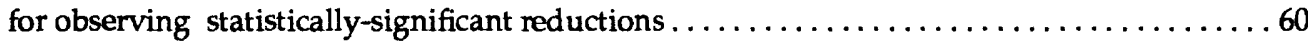


Multiply

inch (in.)

foot $(\mathrm{ft})$

mile (mi)

acre

acre

square mile $\left(\mathrm{mi}^{2}\right)$

cubic foot per second $\left(\mathrm{ft}^{3} / \mathrm{s}\right)$

pound (lb)

pound per acre (lb/acre)

ton, short

ton per square mile per year [(ton $\left./ \mathrm{mi}^{2}\right) / \mathrm{yr}$ ]

degree Fahrenheit $\left({ }^{\circ} \mathrm{F}\right)$
By

To obtain

Length

25.4

0.3048

1.609

Area

4.047

0.4047

2.590

Flow

0.02832

Mass

0.4536

1.121

0.9072

0.3503

Temperature

${ }^{\circ} \mathrm{C}=5 / 9\left({ }^{\circ} \mathrm{F}-32\right)$ cubic meter per second $\left(\mathrm{m}^{3} / \mathrm{s}\right)$

millimeter (mm)

meter (m)

kilometer (km)

square kilometer $\left(\mathrm{km}^{2}\right)$

hectare (ha)

square kilometer $\left(\mathrm{km}^{2}\right)$

kilogram (kg)

kilogram per hectare

( $\mathrm{kg} / \mathrm{ha})$

megagram (Mg)

metric ton per square kilometer per year $\left[\left(\mathrm{t} / \mathrm{km}^{2}\right) /\right.$ annum]

degree Celsius $\left({ }^{\circ} \mathrm{C}\right)$ 


\title{
EVALUATION OF AGRICULTURAL BEST-MANAGEMENT PRACTICES IN THE CONESTOGA RIVER HEADWATERS, PENNSYLVANIA:
}

\author{
Description and Water Quality of the \\ Little Conestoga Creek Headwaters Prior to the \\ Implementation of Nutrient Management
}

\author{
David K. Fishel, Mary Jo Brown, \\ Kevin M. Kostelnik, and Mary A. Howse
}

\begin{abstract}
The headwaters of the Conestoga River are being studied to determine the effects of agricultural BestManagement Practices on surface-water and ground-water quality. As part of this study, a 5.82-squaremile area of the Little Conestoga Creek headwaters (Small Watershed) was monitored during 1984-86, prior to implementation of Best-Management Practices. This report describes the land use and hydrology of this study area and characterizes its surface-water and ground-water quality during the pre-BestManagement Practice phase.

During base-flow conditions, median concentrations of dissolved nitrite plus nitrate nitrogen as nitrogen increased from 2.7 to 8.1 milligrams per liter as the stream flowed through the intensively-farmed carbonate valley. Median total phosphorus increased from 0.05 to 0.20 milligram per liter. Concentrations of dissolved nitrate nitrogen as nitrogen measured in ground water in carbonate rocks in the valley were as great as $\mathbf{2 5}$ milligrams per liter and consistently exceeded 10 milligrams per liter.

Statistical analysis showed that it will require substantial reductions in concentrations and discharges of nitrogen and phosphorus in base flow to obtain statistically measurable improvements in water quality. If concentrations and discharges of total nitrogen in base flow at the five sites are reduced by 15 to 33 percent, and by 63 to 70 percent, respectively, then the Wilcoxon Mann-Whitney rank-sum test will be able to detect an improvement in water quality 95 percent of the time. Likewise, if concentrations of total phosphorus are reduced by 36 to 54 percent, or discharges of total phosphorus are reduced by 52 to 69 percent at the five sites, then an improvement in water quality will be able to be detected 95 percent of the time.
\end{abstract}




\section{INTRODUCTION}

The U.S. Geological Survey (USGS), in cooperation with the Pennsylvania Department of Environmental Resources (PaDER), is studying the Conestoga River Headwaters basin as part of the Rural Clean Water Program (RCWP) directed by the U.S. Department of Agriculture (USDA). The Conestoga River Headwaters RCWP project is 1 of 20 such projects in the nation designed to accelerate the installation of Best-Management Practices (BMPs) for the reduction of agricultural contamination of surface water and ground water. In addition, the Conestoga River Headwaters RCWP project is one of five RCWP projects designated Comprehensive Monitoring and Evaluation Projects. These five RCWP projects are conducting in-depth evaluations on the effectiveness of BMPs for improving rural water quality.

The study area discussed in this report is one of three components--the Regional Network, Small Watershed, and the field site (Field-Site 1 and Field- Site 2) studies-of the Conestoga Headwaters project. The work on this component, the Small Watershed (fig. 1),began in April 1984. Because excessive nutrients are the major problem in the $5.8-\mathrm{mi}^{2}$ (square mile) Small Watershed, the BMPs that will be implemented include nutrient management and animal waste storage. Information presented in this report will help agricultural managers develop nutrient-management plans for farms in the basin.

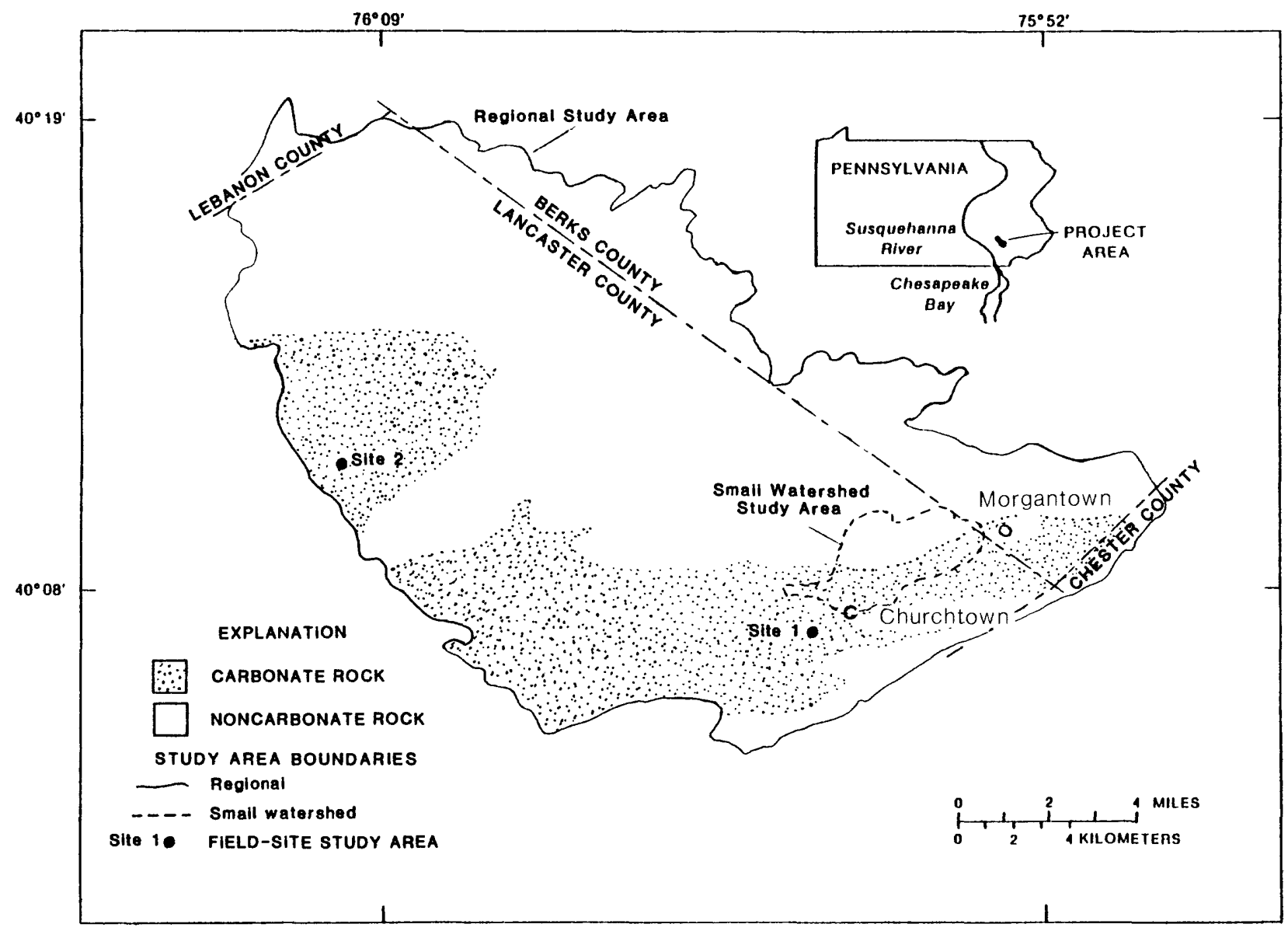

Figure 1.--Location of the Small Watershed in relation to the Regional Study Area.

(From Chichester, 1988.) 


\section{Purpose and Scope}

This report describes and characterizes the water quality of the Small Watershed before implementation of nutrient management (pre-BMP). This basin represents one of the components of the Conestoga River Headwaters RCWP project. The data in this report were collected during the 2-year preBMP phase (April 1, 1984, through March 31, 1986).

This report describes precipitation, land use, soils, streamflow, and surface-water and ground-water quality data collected during the pre-BMP phase. It includes information on the water quality of base flow and stormflow as well as the effects of geology and periodic discharges from agricultural point sources on water quality in the Small Watershed. The report provides estimates of the probability that the sampling scheme will detect changes in water quality in base flow. These probabilities are a function of the magnitude of the underlying change.

\section{Background and Related Studies}

Background and detailed information on the overall project approach and methodology are discussed in "Evaluation of Agricultural Best-Management Practices in the Conestoga River Headwaters, Pennsylvania: Methods of Data Collection and Analysis, and Description of Study Areas," by Chichester (1988). Background specific to the component addressed in this report and studies related to this component are discussed below.

The U.S. Environmental Protection Agency's (USEPA) Chesapeake Bay Study reported that the Susquehanna River contributes 40 percent of the nitrogen and 21 percent of the phosphorus that are discharged to the Bay. Eighty-five percent of this nitrogen and 60 percent of this phosphorus were estimated to have come from cropland runoff (U.S. Environmental Protection Agency, 1983). The Chesapeake Bay Study recommended the implementation of agricultural BMPs to reduce nonpoint-source nutrient discharges. In 1979, the Conestoga River basin was designated the top-priority watershed in Pennsylvania in terms of nonpoint-source contamination of surface and ground water (Schueller, 1983). In 1981, the Conestoga River Headwaters RCWP Project was funded to install BMPs in part of the Conestoga River basin. The USGS and PaDER established the Regional Network component in the $188-\mathrm{mi}^{2}$ Conestoga River Headwaters RCWP project area in 1982 to determine the effects of BMPs on surface-water and ground-water quality. Data collected from the Regional Network from 1982-83 indicated that the major water-quality problem in the upper Conestoga River basin is the elevated nitrate-nitrogen concentrations in the surface water and ground water. Concentrations of nitrate-nitrogen as great as $40 \mathrm{mg} / \mathrm{L}$ (milligrams per liter) as $\mathrm{N}$ were found to be closely associated with intensively farmed areas having carbonate soils (Fishel and Lietman, 1986).

Intensive data collection began in the 5.82- $\mathrm{mi}^{2}$ Small Watershed in April 1984 after maximum concentrations of dissolved-nitrate nitrogen and total phosphorus of 12 and $9.8 \mathrm{mg} / \mathrm{L}$, respectively, were measured there. At this time, the State RCWP Coordinating Committee decided to reduce the scope of the study area from the Regional Network to the Small Watershed where better farmer cooperation was expected. At the same time, a $1.42-\mathrm{mi}^{2}-\mathrm{Nutrient-Management} \mathrm{Subbasin} \mathrm{and} \mathrm{a} 1.43-\mathrm{mi}^{2}-\mathrm{Nonnutrient-}$ Management Subbasin (fig. 2) within the Small Watershed were established.

The Nutrient-Management Subbasin was selected in an area where cooperation with the farmers was expected, and where nutrient management, one of several possible BMPs, was expected to be

implemented. In addition to the traditional BMPs recommended by the Soil Conservation Service (SCS) to reduce soil loss, plans to implement nutrient management are being developed for farms that might have excessive nutrients. The nutrient-management plans can consist of nutrient management in combination with other BMPs, such as animal-waste storage and terracing. Nutrient management is defined as a practice where proper rates and timing of applications of manure and commercial fertilizer are balanced with crop needs to reduce the amount of unused nutrients that become available for transport to streams and ground water. The rates and timing of applications are determined by: (1) considering the amount of residual nitrogen and phosphorus available in the soil for crops; (2) calculating the amount of nutrients 


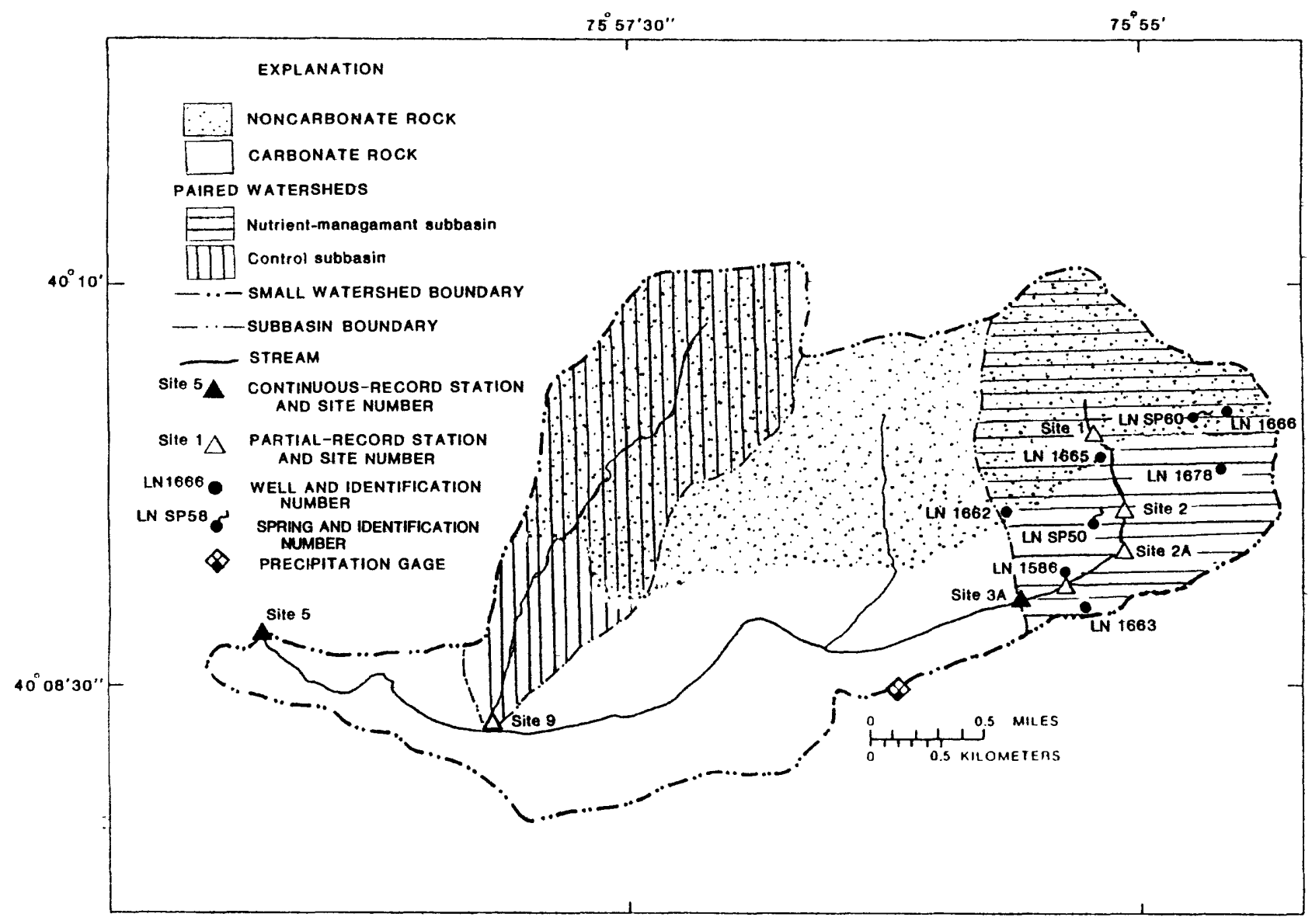

Figure 2.--Small Watershed data-collection locations and general geology. (From Chichester, 1988.)

available from manure applications by testing manure for nutrient content; (3) knowing when and how much commercial fertilizer needs to be added; and (4) understanding when the nutrients can best be utilized by the crops.

Other related monitoring studies were begun in the 1980's as a result of the growing awareness of water-quality problems in the Chesapeake Bay. A lower Susquehanna River nutrient-control project currently is being done by the USGS to determine the effects of BMPs on water quality in noncarbonate areas in Pennsylvania. A study similar to the Conestoga River Headwaters Project is being done by the USGS in the Patuxent River Basin in Maryland. A joint study by the USGS and the Susquehanna River Basin Commission (SRBC) is being done to assess sources of nutrients in the lower Susquehanna River basin. Studies are planned by the PaDER, Bureau of Forestry, with the Lancaster and Lebanon County Conservation Districts to determine the effects of manure disposal on ground water and undisturbed soils.

\section{Approach}

Land use, soil chemistry, and hydrologic data were collected to characterize the water quality of the intensively-farmed Small Watershed. Data were grouped into growing seasons (April through September) and nongrowing seasons (October through March). Precipitation data collected at the southern boundary of the Small Watershed were used to characterize the study period, and to examine any relation between it and storm magnitude, soil chemistry, and water quality in base flow. Land-use data were obtained from farmers in the Nutrient-Management Subbasin to characterize pre-BMP conditions. Soil-chemistry data were collected to characterize the soils in the Nutrient-Management Subbasin and to identify areas where nutrient-management plans might be of most benefit. Base-flow and stormflow water-quality samples were collected to characterize the surface-water quality. Base flow was defined as the streamflow derived 
from ground water and delayed subsurface flow, and representative samples of base flow were collected no sooner than 3 days after any measurable precipitation. Annual loads of nutrients and suspended sediment in base flow, and loads for selected storms were calculated for the Nutrient-Management Subbasin and the Small Watershed. Base-flow data were used for paired-watershed analyses of nutrient concentrations and loads in the Nutrient-Management Subbasin and the Nonnutrient-Management Subbasin. Parametric and nonparametric statistical analyses, such as linear regression and the Wilcoxon Mann-Whitney rank-sum test, were used to examine trends in water-quality concentrations and nutrient and suspended sediment loads in base flow.

Water samples were collected from domestic wells and springs. These data were used to characterize in general the quality of local ground water.

Land-use and water-quality data were synthesized from measured data. Nonparametric statistics and Monte-Carlo simulation were used to estimate the reductions in agricultural contaminants required to detect statistically-significant reductions in concentrations and loads of nitrogen and phosphorus in base flow. A discussion of the hypothetical effects of nutrient management on water quality also is provided.

\section{Acknowledgments}

The following individuals and respective agencies are acknowledged for their assistance in making this project a success:

1. The farmers in the Small Watershed study area for volunteering and assisting with project objectives and providing land-use data.

2. Vincent C. White, Lynn B. Schaffer, and John H. Maljevac from the Pennsylvania Department of Environmental Resources, Bureau of Laboratories, for handling the analysis of water samples.

3. Dr. Dale E. Baker and Leon E. Marshall from the Pennsylvania State University, Department of Agronomy, for helping coordinate the collection of soil samples and for handling the analysis of the soil samples.

4. Omer Brubaker from the U.S. Department of Agriculture, Agricultural Stabilization and Conservation Service, for obtaining land-use data from the farmers, and for making annual field inspections.

5. George Royer, from the Soil Conservation Service in Lancaster County, for assisting with initial contacts with farmers in the Small Watershed, providing nutrient values for livestock and poultry manure, and compiling initial animal population and density data.

6. Richard A. Pennay, from the U.S. Department of Agriculture, Agricultural Stabilization and Conservation Service, for coordinating the transfer of information among the cooperating agencies.

7. Donald Robinson and Robert J. Anderson from the Eastern Lancaster County School District for collecting soil samples, measuring corn yields, and making many recommendations to farmers and project personnel.

8. Richard Maas from the North Carolina State University, Biological and Agricultural Engineering Department, for giving technical advice on data analysis.

9. John Hauenstein and Charles S. Takita from the Susquehanna River Basin Commission for assisting with the collection of water-quality samples. 
Methods of data collection and analysis of precipitation, land use, soils, surface water, and ground water are discussed by Chichester (1988). Data specific to this report are discussed below.

\section{Precipitation}

Precipitation data were collected near the southern boundary of the study area (fig. 2). The precipitation gage, which records accumulated precipitation at 5-minute intervals, was established in midOctober 1982. Data were compared with long-term records from the National Oceanic and Atmospheric Administration (NOAA) gage at Morgantown, $\mathrm{Pa}$. Information from the two precipitation gages at the Conestoga River Headwaters RCWP field sites and the NOAA precipitation gage at Morgantown, Pa., was used to estimate missing records. Two of the gages were within $4 \mathrm{mi}$ (miles) of the study area, and the gage at Field-Site 2 was within $12 \mathrm{mi}$ of the study area (fig. 1).

\section{Land Use and Nutrients}

Land-use data were tabulated from daily records kept by farmers in the Nutrient-Management Subbasin. Figure 3 shows farm locations. Data tabulated included crop acreage, yields, animal population and density, manure export, and daily applications of manure and commercial fertilizer for each field in the Nutrient-Management Subbasin. Field acreage was determined by measurement of aerial photographs and by field inspections each year. Land-use data were stored on a computer in the USGS Harrisburg, Pennsylvania office, and statistical analyses were performed by use of the Statistical Analysis System ${ }^{1}$ (SAS Institute, Inc., 1979; 1982a; 1982b), and P-STAT (P-STAT Inc., 1986) computer packages. The amount of nutrients from manure applied to fields in the Nutrient-Management Subbasin was calculated with knowledge of the typical concentrations of nitrogen and phosphorus supplied by the Agricultural Stabilization and Conservation Service (ASCS) for livestock and poultry manures, and the application records provided by the farmers. Time-series plots of the manure and commercial fertilizer applications were made to determine trends and relations among applications, precipitation, and water quality.

\section{Soil Chemistry}

Soil samples were collected at seven locations (fig. 3) in the Nutrient-Management Subbasin. Samples were collected twice a year; the first samples were collected prior to applications of commercial fertilizer in the spring, and the second samples were collected following the harvest of crops in the fall. Soil core samples were collected to depths of $4 \mathrm{ft}$ (feet) and split into sections representing 0 to 8 in. (inches), 8 to 24 in., 24 to 36 in., and 36 to 48 in. below the land surface. Soluble phosphorus and nitrate-nitrogen concentrations were determined for each section by the Pennsylvania State University, Soils and Environmental Chemistry Laboratory.

\footnotetext{
${ }^{1}$ The use of trade, product, industry, or firm names in this report is for identification or location purposes only and does not constitute endorsement by the U.S. Geological Survey.
} 


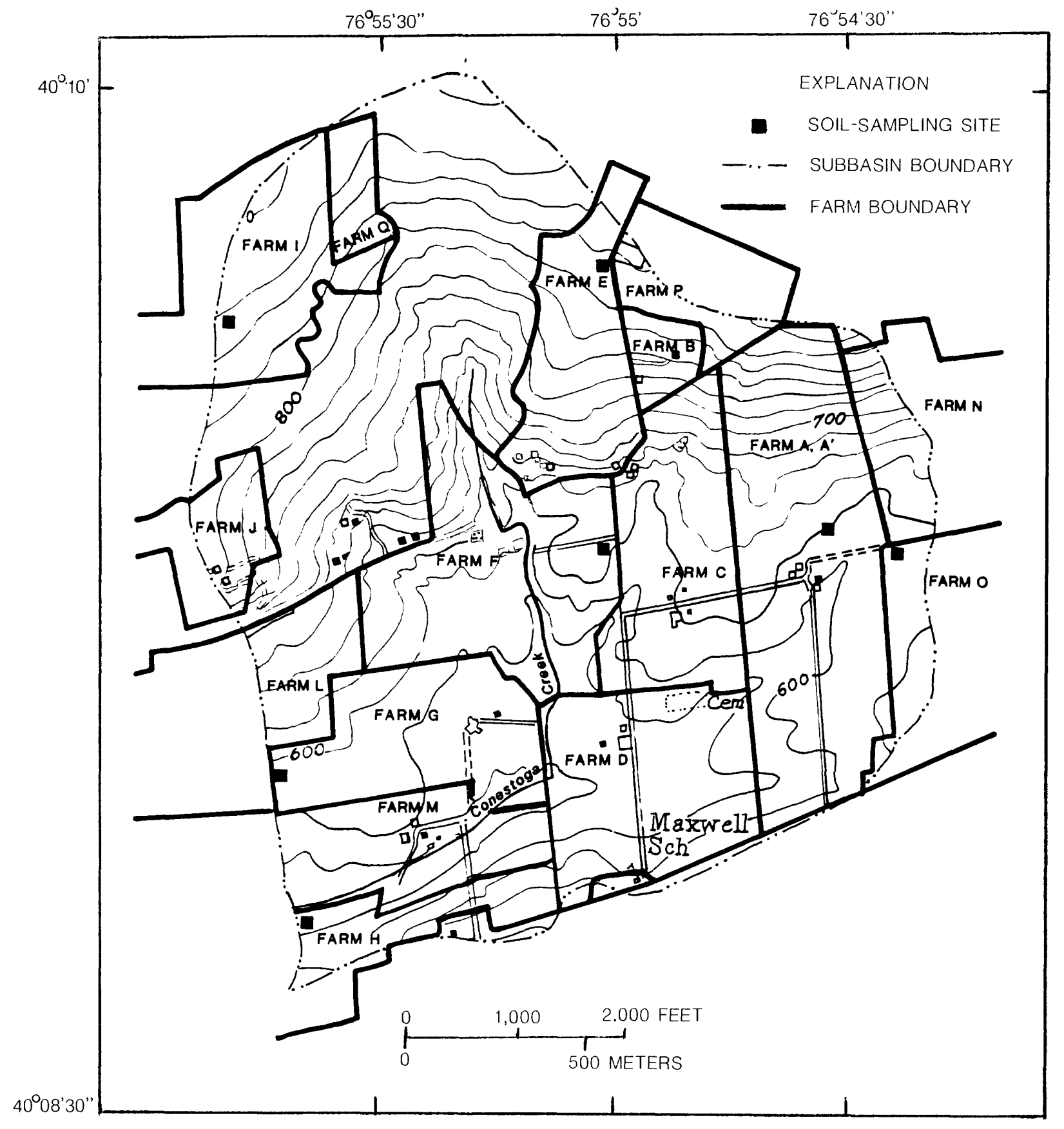

Figure 3.--Farms and soil-sampling sites in the Nutrient-Management Subbasin. 


\section{Streamflow}

Streamflow data were collected at two continuous-record stations and five partial-record stations listed in table 1. Two of the partial-record stations (sites 2 and 3) were discontinued after 1 year of data collection because data from these stations were very similar to data collected at sites $2 \mathrm{~A}$ and $3 \mathrm{~A}$.

Daily mean discharge records for the two continuous-record stations and from the continuous-record station at Lancaster (drainage area $=324 \mathrm{mi}^{2}$ ) along with weather records were compared to characterize the streamflow during the pre-BMP phase. Computer-generated hydrographs for the three stations were overlain to determine the streamflow similarities of the stations. Weather records were compared to determine if precipitation amounts were similar at the three stations.

Streamflow hydrographs for the two continuous-record stations were separated to determine the contributions of ground water (base flow) and surface runoff (stormflow) at each station. The hydrographs were separated by the local minimum technique described by Pettyjohn and Henning (1979) modified for computer use. This technique involved scanning the daily mean-discharge data day by day to determine the lowest value in a preset time interval. This lowest value, the local minimum, was connected by a straight line to the adjacent local minimum. The discharge values were calculated between each local minimum using the slope of the line at each discharge point.

Table 1.-Description of surface-water stations in the Small Watershed and at Lancaster [mi ${ }^{2}$, square miles; mi, miles]

\begin{tabular}{|c|c|c|c|c|c|c|}
\hline $\begin{array}{l}\text { Station } \\
\text { number }\end{array}$ & $\begin{array}{l}\text { Station name, } \\
\text { site number, and } \\
\text { other identifier }\end{array}$ & Location & Latitude & Longitude & Station type & $\begin{array}{c}\text { Drainage } \\
\text { area } \\
\left(\mathrm{mi}^{2}\right)\end{array}$ \\
\hline 015760831 & $\begin{array}{l}\text { Little Conestoga Creek, } \\
\text { Site 1, near Morgantown, Pa. }\end{array}$ & $\begin{array}{l}\text { Upstream side of bridge } \\
\text { on Valley Rd., } 5.5 \mathrm{mi} \\
\text { upstream from mouth }\end{array}$ & 400922 & 755514 & $\begin{array}{l}\text { partial record } \\
\text { gage }\end{array}$ & 0.34 \\
\hline 015760832 & $\begin{array}{l}\text { Little Conestoga Creek, } \\
\text { Site 2, near Morgantown, Pa. }\end{array}$ & $\begin{array}{l}\text { Upstream side of farm } \\
\text { lane, } 5.2 \text { mi upstream } \\
\text { from mouth }\end{array}$ & 400906 & 755505 & $\begin{array}{l}\text { partial record } \\
\text { gage, discontinued } \\
\text { October } 1984\end{array}$ & .60 \\
\hline 0157608325 & $\begin{array}{l}\text { Little Conestoga Creek, } \\
\text { Site } 2 \mathrm{~A} \text {, near Morgantown, Pa. } \\
\text { from }\end{array}$ & $\begin{array}{l}\text { Upstream side of farm } \\
\text { lane, } 5.0 \text { mi upstream } \\
\text { mouth }\end{array}$ & 400858 & 755506 & $\begin{array}{l}\text { partial record } \\
\text { gage }\end{array}$ & .99 \\
\hline 015760833 & $\begin{array}{l}\text { Little Conestoga Creek, } \\
\text { Site 3, near Morgantown, Pa. }\end{array}$ & $\begin{array}{l}\text { Upstream side of farm } \\
\text { lane, } 4.7 \text { mi upstream } \\
\text { from mouth October } 1984\end{array}$ & 400850 & 755524 & $\begin{array}{l}\text { partial record } \\
\text { gage, discontinued } \\
\text { October } 1984\end{array}$ & d 1.34 \\
\hline 0157608335 & $\begin{array}{l}\text { Little Conestoga Creek, } \\
\text { Site 3A, near Morgantown, Pa. } \\
\text { (Nutrient-Management Subbasin) }\end{array}$ & $\begin{array}{l}\text { Upstream side of farm } \\
\text { lane, } 4.5 \text { mi upstream } \\
\text { from mouth }\end{array}$ & 400847 & 755537 & $\begin{array}{l}\text { continuous } \\
\text { record gage }\end{array}$ & 1.42 \\
\hline 015760839 & $\begin{array}{l}\text { Unnamed trib. to Little } \\
\text { Conestoga Creek, Site 9, } \\
\text { at Churchtown, Pa. } \\
\text { (Control Subbasin) }\end{array}$ & $\begin{array}{l}\text { Upstream side of farm } \\
\text { lane, } 0.04 \mathrm{mi} \text { upstream } \\
\text { from mouth. }\end{array}$ & 400820 & 755814 & $\begin{array}{l}\text { partial record } \\
\text { gage }\end{array}$ & 1.43 \\
\hline 1576085 & $\begin{array}{l}\text { Little Conestoga Creek, } \\
\text { near Churchtown, Pa. (Site } 5 \\
\text { and Small Watershed) }\end{array}$ & $\begin{array}{l}\text { Upstream side of bridge } \\
\text { on Smoketown Rd., } 0.7 \mathrm{mi} \\
\text { upstream from mouth }\end{array}$ & 400841 & 755920 & $\begin{array}{l}\text { continuous } \\
\text { record gage }\end{array}$ & 5.82 \\
\hline 01576500 & Conestoga $\mathrm{R}$. at Lancaster, $\mathrm{Pa}$. & $\begin{array}{l}\text { Upstream side of Penn } \\
\text { Central Railroad Bridge, } \\
0.7 \text { mi east of Lancaster }\end{array}$ & 400300 & 761639 & $\begin{array}{l}\text { continuous } \\
\text { record gage }\end{array}$ & 324 \\
\hline
\end{tabular}

\footnotetext{
${ }^{1}$ The original source of reference for the Little Conestoga Creek referred to in this report comes from the U.S. Geological Survey Morgantown Quadrangle of 1939. The 1975 photorevision of the Morgantown Quadrangle designates the stream as an unnamed tributary to the Conestoga River. The Little Conestoga Creek referred to in this report should not be confused with the Little Conestoga Creek that discharges to the Conestoga River near Safe Harbor and is found on the Conestoga Quadrangle.
} 


\section{Water Quality}

The water-quality characteristics measured and the sampling frequencies for surface-water and ground-water sites are listed in table 2 . All nutrient samples were preserved with mercuric chloride. Samples from selected storms were analyzed to characterize the stormflow during the growing and nongrowing seasons. An average of eight sediment and eight nutrient samples were collected during each selected storm. All samples were analyzed by approved procedures (Skougstad and others, 1979; U.S. Environmental Protection Agency, 1979, 1985). Suspended-sediment samples were analyzed by the USGS sediment laboratory in Harrisburg, Pa. Nutrient and pesticide samples were analyzed by the PaDER, Bureau of Laboratories, in Harrisburg, Pa. Water-quality data collected during this study are published in USGS Water-Resources Reports PA-84-2, PA-85-2, and PA-86-2 (U.S. Geological Survey, 1986, 1987, 1988). The data are catalogued by the USGS identification numbers shown in this report.

Preliminary laboratory results were retrieved and evaluated routinely to identify questionable samples and results at an early stage. Requests were submitted for the reanalysis of these samples. Depending on the constituents involved, the samples were either reanalyzed or the resulting calculations were checked and recalculated.

A quality-assurance plan was developed for the entire ConestogaHeadwaters project. This plan has been maintained throughout the project with the PaDER Bureau of Laboratories which performed the analysis of all nutrient and pesticide samples.

Several types of samples were used to evaluate the quality of data. Blank samples of distilled water were routinely submitted for analysis. These samples evaluated the laboratory's baseline capabilities at near detection-limit levels. Standard USEPA and USGS reference water-quality samples also were submitted for analysis on a routine basis. These samples were used to determine laboratory accuracy. Duplicate water-quality samples were split in the field and also submitted to the Bureau of Laboratories for analysis. This third sample type measured the laboratory repeatability of the individual parameters.

The Wilcoxon two-sample (Mann-Whitney rank sum) test and the Wilcoxon signed-rank (or onesample) test-standard statistical procedures defined by Noether (1976)-were used to evaluate the quality of the Conestoga nutrient data. Quality-assurance data were collected throughout the pre-BMP phase.

Nutrient concentrations of blank samples should be near detection limits to constitute acceptable laboratory results. The statistical comparison of this data first required the calculation of the difference between the reported values and the detection limits for each property or character in each sample. These differences should be approximately equal to zero. A signed-rank test was performed on the differences to test this hypothesis. The results indicated that the means of the calculated concentrations were statistically different from the detection limits for total and dissolved ammonia and total and dissolved ammonia plus organic nitrogen. This could indicate either a positive bias for reported values of these constituents at concentration levels near detection limits, or less than pure distilled water blanks.

Standard reference samples were analyzed for total and dissolved ammonia, ammonia plus organic nitrogen, nitrate-nitrogen, and phosphorus. Evaluation of the signed-rank test results showed a statistically measurable difference between the measured and the expected values for dissolved nitrate, total ammonia, total ammonia plus organic nitrogen, and total and dissolved phosphorus at the 95-percent confidence level. Except for total ammonia plus organic nitrogen, the median difference between the known and reported values was $0.10 \mathrm{mg} / \mathrm{L}$ or less. The reported results for all other parameters did not differ significantly from their expected values at a 95-percent confidence level.

The duplicate data were compared by use of the Wilcoxon two-sample test, which compared the data as two independent groups. The results of this test showed no statistically measurable difference between groups for any constituent, indicating that there is good repeatability in laboratory analysis. 
Table 2-Water-quality characteristics measured and sampling frequencies at surface-water and ground-water sites [Surface-water sites include sites where base flow was sampled monthly and 14 to 22 storms were sampled annually. Ground-water sites were sampled quarterly.]

\begin{tabular}{|c|c|c|c|}
\hline $\begin{array}{l}\text { Constituents and } \\
\text { properties measured at } \\
\text { surface-water sites }\end{array}$ & & $\begin{array}{r}\text { Constit } \\
\text { properties } \\
\text { ground- }\end{array}$ & $\begin{array}{l}\text { uents and } \\
\text { measured at } \\
\text { water sites }\end{array}$ \\
\hline $\begin{array}{l}\text { Specific conductance } \\
\text { Water temperature } \\
\text { Suspended sediment } \\
\text { Total and dissolved: }\end{array}$ & $\begin{array}{l}\text { Nitrite nitrogen } \\
\text { Nitrite + nitrate nitrogen } \\
\text { Ammonia nitrogen } \\
\text { Ammonia + organic nitrogen } \\
\text { Phosphorus }\end{array}$ & Dissolved: & $\begin{array}{l}\text { Nitrite nitrogen } \\
\text { Nitrite + nitrate nitrogen } \\
\text { Ammonia nitrogen } \\
\text { Ammonia + organic nitrogen } \\
\text { Phosphorus }\end{array}$ \\
\hline Total pesticides: & $\begin{array}{l}\text { Alachlor } \\
\text { Atrazine } \\
\text { Cyanazine } \\
\text { Metolachlor } \\
\text { Propazine } \\
\text { Simazine } \\
\text { Toxaphene }\end{array}$ & & \\
\hline
\end{tabular}

The quality of the nutrient data for the Conestoga River Headwaters project collected during the Small Watershed pre-BMP period has been evaluated with several statistical procedures and sample types. The results of this evaluation, summarized in table 3 , indicate that there was an acceptable degree of repeatability by the laboratory for all analyzed water-quality characteristics. The analyses were found to be accurate for most characteristics. Total ammonia plus organic nitrogen and total phosphorus exhibited some error because of the limitation of analysis techniques. Although more error was associated with these characteristics for concentrations near detection limits, actual samples rarely had concentrations near detection limits.

Daily chemical loads in base flow were computed using the daily base-flow data generated from hydrograph separations, the measured or estimated daily concentration data, and equation (1).

$$
\mathrm{L}=\mathrm{Q} \times \mathrm{C} \times 5.4 \text {, }
$$

where $\mathrm{L}=$ chemical load, in pounds per day;

$Q=$ streamflow, in cubic feet per second;

$\mathrm{C}=$ constituent concentration, in milligrams per liter; and

5.4 = a conversion factor for converting the product to pounds per day.

Estimates of nutrient concentrations were made by straight-line interpolation between days when base-flow samples were collected. Monthly and annual base-flow nutrient loads were calculated as the sum of the daily nutrient loads.

Nutrient loads were calculated for selected storms. The subdivided-day method described by Porterfield (1972) was used to calculate nutrient storm loads.

Water-quality data from base-flow samples were analyzed using summary statistics, time-series trend analyses, and paired-watershed analyses. Univariate statistics were tested for normality. Data that were not normally distributed were log-transformed and then tested for normality. Time-series plots were used to examine trends and relations among precipitation, nutrient applications, and water-quality concentrations of nutrients and discharges. Data were grouped into two seasons: April through September was considered the growing season and October through March was the nongrowing season. Correlations between the quality of water at the Nutrient-Management and the Nonnutrient-Management Subbasins were determined by paired-watershed analyses (Spooner and others, 1985). 


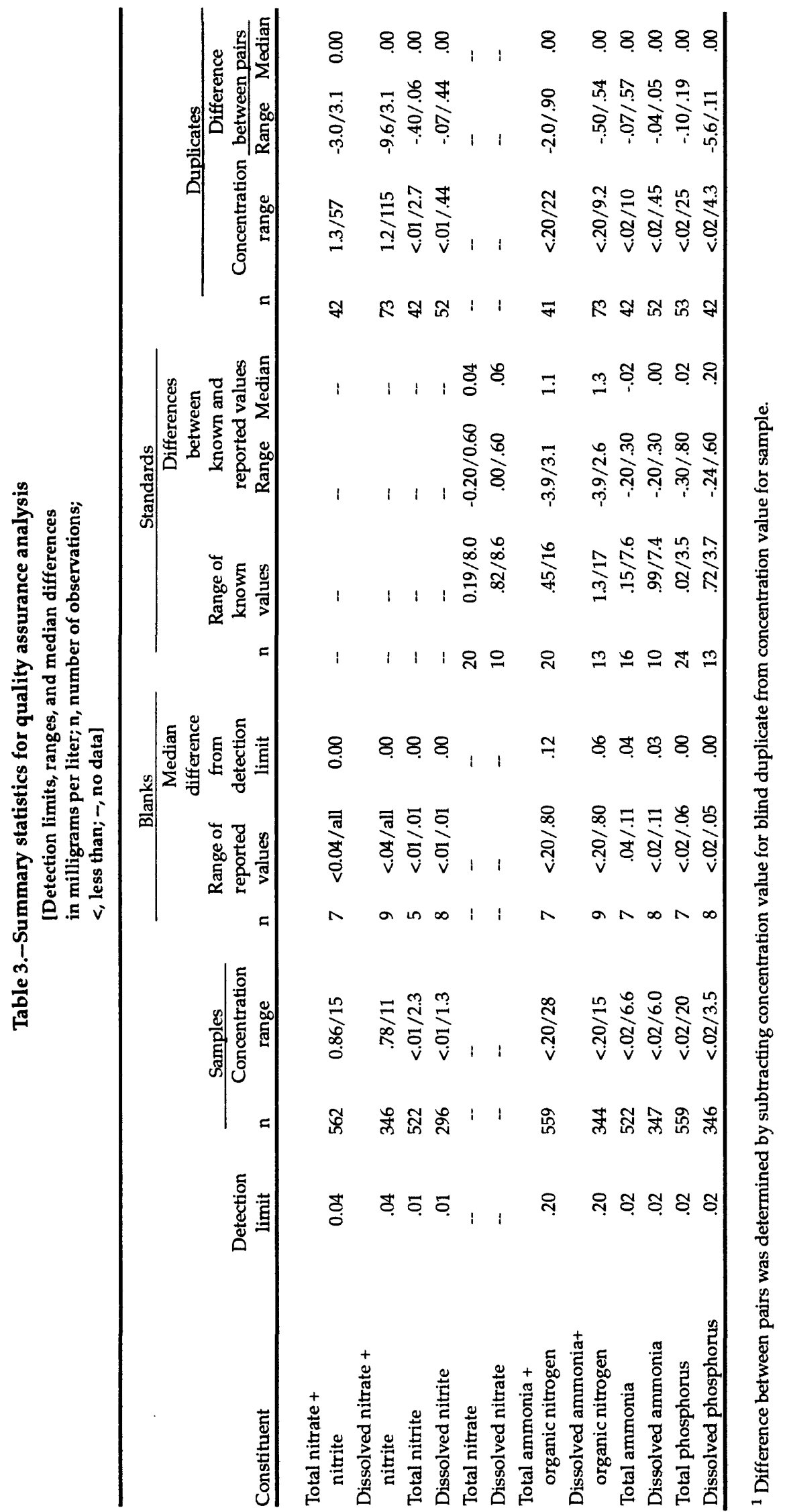




\section{Estimating Reductions in Agricultural Contaminants \\ Required for Observing a Statistically-Significant Reduction}

Monte Carlo experiments were conducted to determine the likelihood of detecting changes in water quality between the pre-BMP and post-BMP periods, using the proposed methods suggested by Martin and Hirsch (U.S. Geological Survey, written commun., 1989), as a function of the magnitude of true reductions in the concentrations. It was assumed that changes in the water quality would be indicated by a statistically-significant result from a Wilcoxon-Mann-Whitney test applied to the pre-BMP and post-BMP water-quality data (R.M. Hirsch, U.S. Geological Survey, written commun., 1989; Crawford and others, 1983). The null hypothesis assumed the medians of the two populations were the same. An alpha level of 0.05 was assumed throughout the analysis.

Monte Carlo simulation suggested by Martin and Hirsch (U.S. Geological Survey, written commun., 1989) was used to synthesize pre- and post-BMP data because of the limited amount of measured data, and to develop power curves from the rank-sum test. The pre-BMP data were synthesized by randomly generating 1,000 data sets based on the characteristics of the measured data, the number of seasons, the total number of observations in each season, and the mean and standard deviations for each season during the pre-BMP phase. Post-BMP data were synthesized by reducing the mean and the standard deviation of the pre-BMP data by a selected percentage. A second approach for generating post-BMP data from preBMP data for normally distributed data was to reduce the mean by the selected percentage without changing the standard deviation. The mean of the distribution of the generated post-BMP data was reduced until the power of the test exceeded 0.999. As the mean of the synthesized post-BMP data would logically only be lower than the mean of the pre-BMP data, the null hypothesis could only be rejected from one direction; thus, a one-tailed test was performed. 


\section{DESCRIPTION OF THE SMALL WATERSHED STUDY AREA}

\section{Surface-Water Basin and Sampling Sites}

The 5.82- $\mathrm{mi}^{2}$ Small Watershed is located in parts of Lancaster and Berks Counties, south-central Pennsylvania (fig. 1). The Small Watershed lies in two sections of the Piedmont physiographic province. The northern half, characterized by the broad highlands and ridges, is in the Triassic Lowland section and is underlain by conglomerate, sandstone, shale, and diabase of the Hammer Creek Formation and the sandstone, mudstone, and shale of the Stockton Formation. The southern half of the watershed, characterized by rolling lowlands, is in the Cambrian and Ordovician Conestoga Valley section and is underlain by carbonate rock from the Buffalo Springs and Stonehenge Formations. The study area has had a complex geologic history with repeated episodes of folding and faulting, as evidenced by the presence of Triassic Formations unconformably overlying Cambrian Formations.

Part of the Small Watershed was divided into two subbasins similar in size, geology, and land use to help characterize water quality and determine the effects of nutrient management on water quality. In the eastern part of the Small Watershed, a $1.42-\mathrm{mi}^{2}$ subbasin was designated as the Nutrient-Management Subbasin and contains all or parts of 16 farms (fig. 3). Fourteen of the farmers have volunteered to cooperate with the agencies working on the Conestoga River Headwaters RCWP Project.

A $1.43-\mathrm{mi}^{2}$ subbasin in the northwestern part of the Small Watershed was designated as the Nonnutrient-Management Subbasin. Water-quality, streamflow, and limited land-use data for the Nonnutrient-Management Subbasin are being collected, but nutrient management is not planned for farms in this subbasin. Therefore, applications of nutrients in the Nonnutrient-Management Subbasin during the post-BMP phase should not differ substantially from the nutrient applications during the preBMP phase. Together, the Nutrient-Management and Nonnutrient-Management Subbasins are called the Paired Watersheds (fig. 2).

\section{Aquifer and Ground-Water Sampling Sites}

The aquifer in the Small Watershed is unconfined, and is composed of regolith overlying bedrock of the Hammer Creek, Stockton, Buffalo Springs, and Stonehenge Formations. Ground-water flow can be relatively rapid compared to the flow rate in isotropic aquifers, and is anisotropic because of the many fractures and solution-enlarged cavities in the carbonate rocks. The hydraulic connection between the weathered mantle and the secondary openings in the underlying bedrock is good because there are no well-defined confining units.

Ground-water data were collected within the Nutrient-Management Subbasin from three wells and one spring located in the carbonate-rock floored valley and three wells and one spring located in the sandstone and shale area. Locations of the wells and springs are shown in figure 1 and descriptions are given in table 4.

\section{Precipitation}

Normal yearly precipitation for the study area is about 42 in. based on long-term records from the NOAA station in Morgantown, Pa. Monthly averages range from 2.6 in. for February to 4.2 in. for August.

About 76 in. of precipitation, 10 percent less than normal, fell during the 2-year pre-BMP phase. Precipitation was 14 percent below normal during the first year and 5 percent below normal during the second year. Precipitation was more than 1.0 in. below normal for 12 of the 24 months of the pre-BMP phase, and more than $1.0 \mathrm{in}$. above normal for 6 of the months (fig. 4). Precipitation was 5 percent above normal during the 1984 growing season (April-September), and was 11 percent above normal during the 1985 growing season. 
Table 4.-Description of ground-water sampling sites

\begin{tabular}{lllll}
\hline Site & Latitude & Longitude & \multicolumn{1}{c}{$\begin{array}{c}\text { Geologic } \\
\text { formation }\end{array}$} & $\begin{array}{c}\text { Well or } \\
\text { spring }\end{array}$ \\
\hline LN SP59 & 400900 & 755515 & Buffalo Springs Formation ${ }^{1}$ & spring \\
LN SP60 & 400926 & 755445 & Stockton Formation ${ }^{2}$ & spring \\
LN 1586 & 400853 & 755521 & Buffalo Springs Formation & well \\
LN 1662 & 400910 & 755544 & Stockton Formation & well \\
LN 1663 & 400843 & 755527 & Buffalo Springs Formation & well \\
LN 1665 & 400922 & 755511 & Stockton Formation & well \\
LN 1666 & 400926 & 755436 & Stockton Formation & Buffalo Springs Formation \\
LN 1678 & 400918 & 755439 & & well \\
\hline
\end{tabular}

${ }^{1}$ Buffalo Springs Formation (Cambrian) is light gray to pinkish gray, finely to coarsely crystalline limestone, and interbedded dolomite; numerous siliceous and clayey laminae, stromatolitic limestone beds near top; some thin sandy beds (Berg and others, 1980).

${ }^{2}$ Stockton Formation (Triassic) is lightgray to buff, coarse grained, arkosic sandstone, includes reddish-brown to grayish-purple sandstone, mudstone, and shale (Berg and others, 1980).

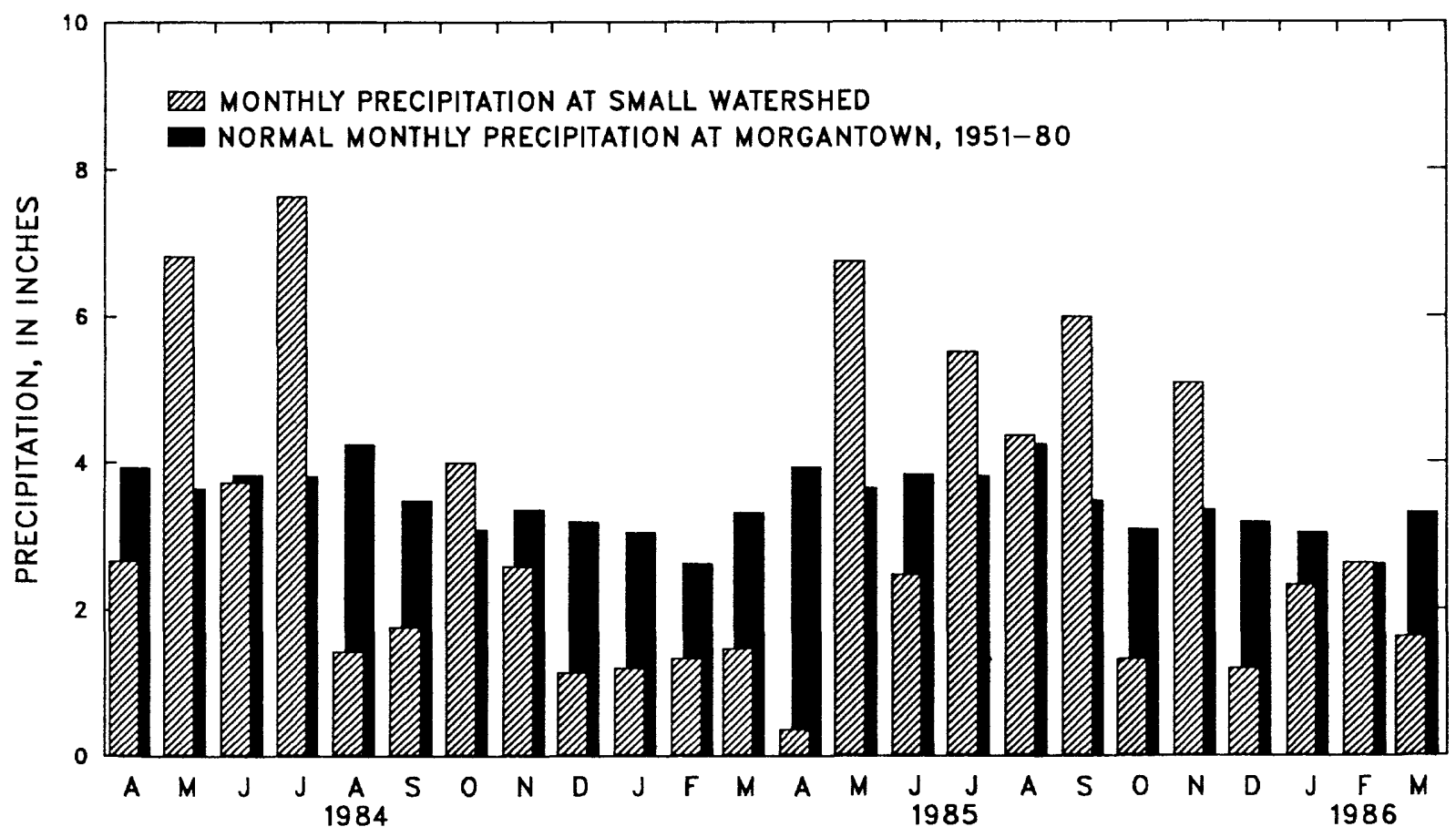

Figure 4.--Monthly precipitation at the Small Watershed and normal monthly precipitation at Morgantown. 
Precipitation was in the form of rain during most of the year, but commonly in the form of snow in January and February. Three storms produced more than 2 in. of rain, and 15 storms produced more than $1 \mathrm{in}$. of rain during the 2-year study. These 18 storms accounted for about 40 percent of the precipitation that fell in the study area. The largest amount of precipitation from any single event occurred on September 26 and 27, 1985, when Hurricane Gloria produced 5.4 in. of precipitation in 18.5 hours. Without the hurricane, the second year of the study would have been 25 percent drier than normal.

Occasionally, there were large differences in the amount of precipitation between the sites in the study area, particularly during thunderstorms. These differences can produce differences in surface runoff and base flow at the two continuous-record sites. For example, the precipitation station for the study area recorded $1.1 \mathrm{in}$. of rain during a storm on August 14, 1985, while $2.4 \mathrm{mi}$ away only $0.11 \mathrm{in}$. of rain was recorded.

\section{Land Use and Agricultural Activity}

The Small Watershed is in one of the most productive agricultural regions in the nation (Pennsylvania Department of Agriculture, 1985). Most Lancaster County farms are farmer-operated; the average size is 84 acres, 75 percent of which is under cultivation. The 16 farms that are either totally or partly in the Nutrient-Management Subbasin are typical of those in Lancaster County. Only two of these farms comprise more than 100 acres, and about 85 percent of the farm land is cultivated. Of the 16 farms in the Nutrient-Management Subbasin, 14 provide detailed land-use data. One of the farms that does not provide information represents 9 percent of the basin and is typical of this subbasin. The other is a small farm where no commercial fertilizer is used, and which comprises less than 1 percent of the basin.

Seventy-eight percent of the land in the Nutrient-Management Subbasin is used for agricultural purposes. Table 5 lists the land uses and the acreage devoted to each agricultural land use. Most of the land devoted to pasture borders the stream in the Nutrient-Management Subbasin, and the cattle have free access to the stream when they are grazing. The nonagricultural uses include residential, commercial, and wooded areas. Because only a small percentage of the land is devoted to residential use and the number of people in the Nutrient-Management Subbasin is small, human waste was not considered to be a major contributor of nutrients.

Table 5.-Land use and crop acreage in the Nutrient-Management Subbasin, April 1, 1984, through March 31, 1986

\begin{tabular}{lcc}
\hline Land use & Percentage of total acreage & Percentage of agricultural acreage \\
\hline Agricultural & 78 & \\
corn & & 52 \\
hay & 22 \\
pasture & 8 \\
noncropland & 22 & 18 \\
Nonagricultural & 100 & \\
Total & & \\
\hline
\end{tabular}


Three farms in the 1.42- $\mathrm{mi}^{2}$ Nutrient-Management Subbasin-farms E, J, and a farm located on the northern border of the subbasin that is not identified in figure 3 because of its small contribution to the subbasin-were sold in 1986. No major changes in farm operation during the pre-BMP phase were documented after these farms were sold.

Land-use information from field reconnaissance of an area upstream from Site 1 (fig. 2) revealed that many used pesticide containers were scattered throughout the wooded area. The containers were removed from the area after the first year of the study.

\section{Crop Acreage and Corn Yields}

About 750 of the 909 acres in the Nutrient-Management Subbasin are planted in crops. About 52 percent of the total acreage is planted in corn, 22 percent is planted in hay (alfalfa or alfalfa and grass mixes), and 8 percent is pasture (table 5). Crop rotation commonly is practiced in the study area. Dairy farmers in the study area generally rotate crops using a schedule of 2 years for corn and 3 years for alfalfa. Agricultural-activities data provided by the farmers indicate about 40 percent of the total crop acreage in the Nutrient-Management Subbasin is rotated to a different crop each year. About 89 acres were rotated from alfalfa to corn in 1985.

The median corn yield for 11 farms in the Nutrient-Management Subbasin was 149 bushels/acre (bushels per acre). Yields ranged from 89 to 187 bushels/acre (table 6).

Table 6.-Average corn yields at farms in the Nutrient-Management Subbasin, April 1, 1984, through March 31, 1986

[Corn yield, in bushels per acre]

\begin{tabular}{lc}
\hline Farm & Average corn yield \\
\hline A & 151 \\
A $^{\prime}$ & 157 \\
B & 187 \\
D & 147 \\
E & 89 \\
G & 142 \\
H & 154 \\
I & 149 \\
J & 137 \\
L & 139 \\
M & 149 \\
\hline
\end{tabular}




\section{Animal Population and Density, and Manure Production}

Dairy comprised about 43 percent of the animal population in the Nutrient-Management Subbasin on the basis of animal units; dairy comprised 23 percent; and hogs comprised 18 percent during the pre-BMP phase. Animal populations vary from year to year depending on the marketability of the animal. Table 7 shows the changes in animal populations in terms of animal units during 1984-85. The most significant change was the increase in beef cattle by about 35 animal units. The number of dairy cattle also increased slightly. Swine numbers decreased by about 25 animal units.

The Conestoga River Headwaters Plan of Work (U.S. Department of Agriculture, 1982) classified farms with more than 1.5 AU/acre (animal units per acre) as being critical areas in terms of nonpoint-source agricultural pollution. Animal densities for five of the farms in the Nutrient-Management Subbasin are greater than 1.5 AU/acre (table 8). When animal density is calculated using the amount of corn acreage available for manure disposal, then the densities range from 1.1 to $3.14 \mathrm{AU} /$ acre.

In addition to animal population, table 7 also lists the corresponding amount of manure and nutrients produced by each animal type. About 14,000 tons of manure were produced in 1984 and in 1985, at 14 cooperating farms in the Nutrient-Management Subbasin. Manure is generally stored for only 3 to 5 weeks, because most of the farms have limited facilities for manure storage. Therefore, manure is spread throughout the year, even during the nongrowing season.

Table 7.-Animal types and manure production in the Nutrient-Management Subbasin during $1984-85$

\begin{tabular}{|c|c|c|c|c|c|c|c|c|}
\hline \multirow[b]{2}{*}{ Animal type } & \multicolumn{2}{|c|}{$\begin{array}{c}\text { Animal }^{1} \\
\text { units }\end{array}$} & \multicolumn{2}{|c|}{$\begin{array}{c}\text { Manure }{ }^{2} \\
\text { (tons) }\end{array}$} & \multicolumn{2}{|c|}{$\begin{array}{c}\text { Nitrogen } \\
\text { (pounds as N) }\end{array}$} & \multicolumn{2}{|c|}{$\begin{array}{l}\text { Phosphorus } \\
\text { (pounds as } \mathrm{P} \text { ) }\end{array}$} \\
\hline & 1984 & 1985 & 1984 & 1985 & 1984 & 1985 & 1984 & 1985 \\
\hline Dairy cows & 478 & 471 & 7,410 & 7,300 & 74,100 & 73,000 & 13,040 & 12,850 \\
\hline Beef cattle & 105 & 141 & 1,155 & 1,550 & 12,705 & 17,060 & 4,065 & 5,460 \\
\hline Swine & 215 & 189 & 1,890 & 1,660 & 26,490 & 23,270 & 8,325 & 7,315 \\
\hline Poultry & 254 & 259 & 2,790 & 2,850 & 83,700 & 85,470 & 24,550 & 25,070 \\
\hline Horses & 25 & 25 & 415 & 415 & 4,980 & 4,980 & 915 & 915 \\
\hline Sheep & $\underline{26}$ & $\underline{23}$ & $\underline{170}$ & $\underline{150}$ & $\underline{3,785}$ & $\underline{3,345}$ & $\underline{605}$ & $\underline{535}$ \\
\hline Totals & 1,103 & 1,108 & 13,830 & 13,925 & 205,760 & 207,125 & 51,500 & 52,145 \\
\hline
\end{tabular}

${ }^{1}$ One animal unit is equivalent to 1,000 pounds of animal weight.

Table 8.-Animal densities of farms in the Nutrient-Management Subbasin based on total crop acreage where manure may be applied

[AU, animal units]

\begin{tabular}{|c|c|c|c|c|c|}
\hline Farm & $\begin{array}{c}\text { Crop acreage } \\
\text { (acres) }\end{array}$ & $\begin{array}{l}\text { Animal density } \\
\text { (AU/acre) }\end{array}$ & Farm & $\begin{array}{c}\text { Crop acreage } \\
\text { (acres) }\end{array}$ & $\begin{array}{c}\text { Animal density } \\
\text { (AU/acre) }\end{array}$ \\
\hline$A-A^{\prime 1}$ & 106 & 1.20 & $\mathrm{H}$ & 32 & 3.14 \\
\hline B & 75 & 1.17 & I & 44 & 1.64 \\
\hline D & 55 & 2.41 & $\mathrm{~J}$ & 126 & 1.14 \\
\hline $\mathrm{E}$ & 27 & .91 & $\mathrm{~L}$ & 70 & 1.59 \\
\hline G & 82 & 1.17 & $\mathbf{M}$ & 34 & 1.78 \\
\hline
\end{tabular}

${ }^{1}$ One farmer operates both farms. 


\section{Nutrient Applications and Manure Export}

Nutrients are applied to fields in the Nutrient-Management Subbasin as either manure or commercial fertilizer. Figure 5 shows the timing of nutrient applications during the pre-BMP phase. Most of the commercial fertilizer was applied in May and June near the beginning of the growing season. Exceptions were two applications of phosphorus to alfalfa fields made in July and August 1984. These applications of a 7-21-7 commercial fertilizer (7 percent $\mathrm{N}, 21$ percent $\mathrm{P}_{2} \mathrm{O}_{5}, 7$ percent $\mathrm{K}_{2} \mathrm{O}_{5}$ ) were applied to fields that were deficient in phosphorus near Site $2 \mathrm{~A}$, and were rotated to corn in 1985 . The sum of these two applications was about $1,040 \mathrm{lb}$ of phosphorus-about 14 percent of the annual commercial fertilizer application of phosphorus.

Figure 5 also shows that most of the nitrogen and phosphorus was applied as manure. Often, manure was spread in the winter when the ground was frozen and tractors or horse-drawn manure spreaders were able to traverse the fields. If the fields were wet, heavy equipment could not be used, and the manure was piled near the barns or deposited on the closest fields.

Typical manure values and the estimated amount of manure produced by various animal types are listed in table 9. The nutrient content of manure depends on the animal type, moisture content, and the type and amount of bedding material in the manure. For example, manure from poultry, which comprised an average of 50 percent of the animal units in the Nutrient-Management Subbasin, contains three times more nitrogen and five times more phosphorus than does dairy manure. Some farmers in the NutrientManagement Subbasin mixed the manure from more than one animal type before it was applied to cropland. Because manure samples were not collected and analyzed before each application, the nutrient content of the manure applied was calculated from the nutrient values shown in table 9.

Table 9.-Manure production and nutrient content of manure by animal type [tons/yr, tons per year; lb/ton, pounds per ton]

\begin{tabular}{lcccc}
\hline & \multicolumn{2}{c}{$\begin{array}{c}\text { Estimated manure produced } \\
\text { by one animal unit }\end{array}$} & \multicolumn{2}{c}{$\begin{array}{c}\text { Nutrient content }{ }^{3} \\
\text { (lb/ton) }\end{array}$} \\
\cline { 2 - 5 } Animal type & (tons/yr) & (percent solids) & & Phosphorus \\
\hline & & & 10 & 1.8 \\
Dairy cows & 15.5 & 15 & 11 & 3.5 \\
Beef cattle & 11.0 & 15 & 14 & 4.4 \\
Swine & 8.8 & 14 & 30 & 8.8 \\
Poultry & 11.0 & 25 & 22 & 3.5 \\
Sheep & 6.6 & 25 & 12 & 2.2 \\
Horses & 8.2 & 21 & 2 & \\
\hline
\end{tabular}

\footnotetext{
${ }^{1}$ One animal unit is equivalent to 1,000 pounds of animal weight.

2 U.S. Department of Agriculture, Agricultural Stabilization and Conservation Service, written commun., 1985.

${ }^{3}$ Pennsylvania Department of Environmental Resources, Bureau of Water Quality Management, Manure Management For Environmental Protection.
}

About $203,150 \mathrm{lb}$ of nitrogen and $51,000 \mathrm{lb}$ of phosphorus were reported by the farmers to have been applied as manure in the Nutrient-Management Subbasin during the pre-BMP phase (table 10). An additional $83,800 \mathrm{lb}$ of nitrogen and $18,100 \mathrm{lb}$ of phosphorus were estimated to have been deposited by animals grazing in pastures near the stream. Therefore, about 85 percent of the total $337,610 \mathrm{lb}$ of nitrogen and 84 percent of the total $82,240 \mathrm{lb}$ of phosphorus applied in the Nutrient-Management Subbasin came from manure. The largest nitrogen application for a single day, $10,740 \mathrm{lb}$, was made at farm $\mathrm{D}$ (fig. 3) on September 5, 1985. This single application of 600 tons of hog and chicken manure was applied to a pasture. The largest phosphorus application, 3,830 lb, was on October 11, 1985. More than 95 percent of the phosphorus applied on October 11 was from hog and chicken manure spread on several fields at farm D, after corn was harvested and before wheat was planted. 

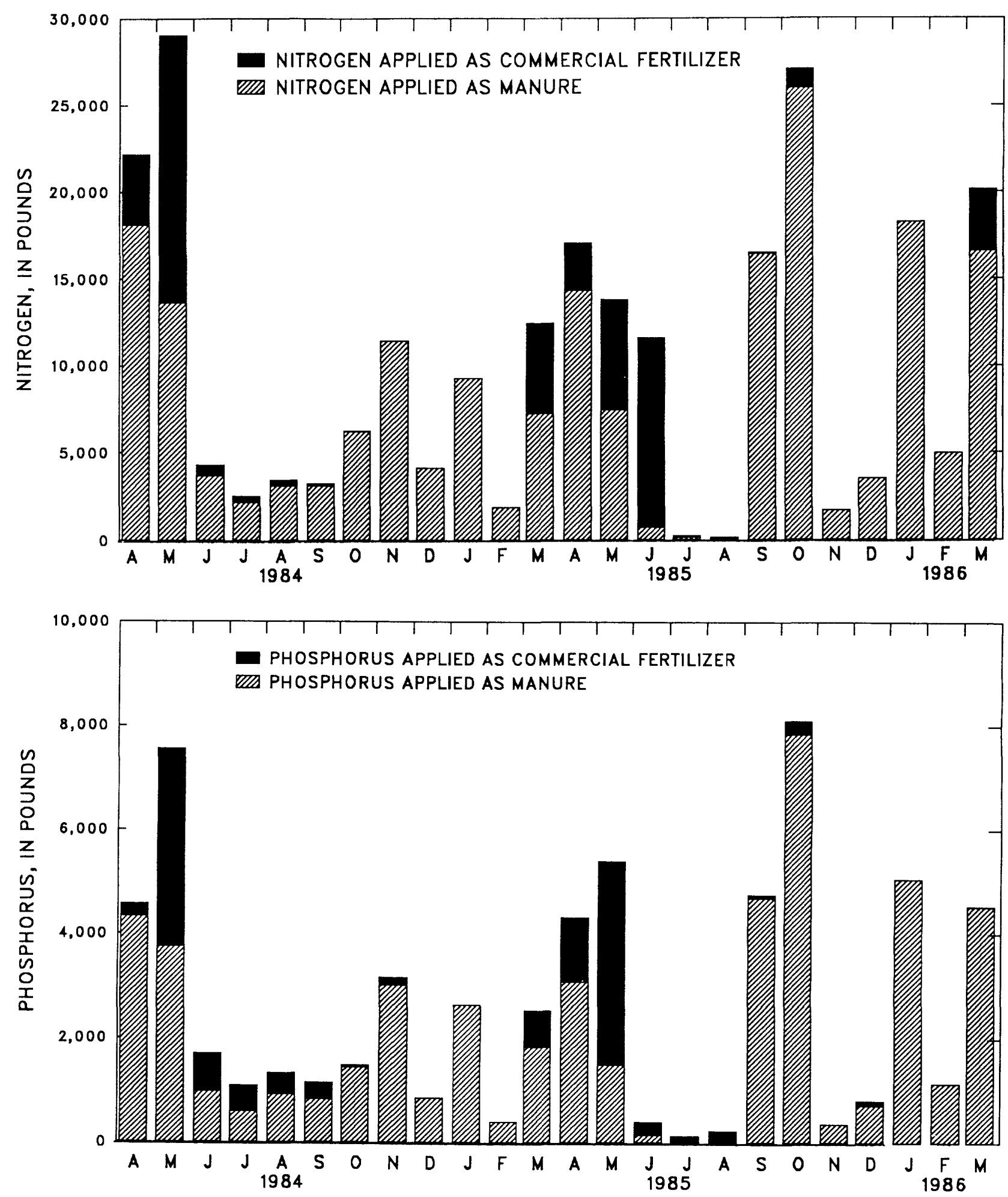

Figure 5.--Nutrient applications as reported by farmers in the Nutrient-Management Subbasin during the preBest-Management Practice phase, April 1, 1984, through March 31, 1986. 
Table 10.-Amounts of manure and commercial fertilizer spread on fields in the Nutrient-Management Subbasin, April 1, 1984 through March 31, 1986 [lb, pounds]

\begin{tabular}{|c|c|c|c|c|c|c|c|c|}
\hline \multirow[b]{2}{*}{ Farm } & \multirow[b]{2}{*}{ Year } & \multirow{2}{*}{$\begin{array}{c}\text { Manure } \\
\text { applied } \\
\text { (tons) }\end{array}$} & \multicolumn{3}{|c|}{ Nitrogen } & \multicolumn{3}{|c|}{ Phosphorus } \\
\hline & & & $\begin{array}{l}\text { Manure } \\
\text { (lb) }\end{array}$ & $\begin{array}{l}\text { Fertilizer } \\
\text { (lb) }\end{array}$ & $\begin{array}{c}\text { Total } \\
\text { (lb) }\end{array}$ & $\begin{array}{l}\text { Manure } \\
\text { (lb) }\end{array}$ & $\begin{array}{c}\text { Fertilizer } \\
\text { (lb) }\end{array}$ & $\begin{array}{l}\text { Total } \\
\text { (lb) }\end{array}$ \\
\hline \multirow[t]{2}{*}{$A-A^{\prime}$} & $\begin{array}{l}1 \\
2\end{array}$ & $\begin{array}{l}1,634 \\
1,629 \\
\end{array}$ & $\begin{array}{l}22,550 \\
26,300 \\
\end{array}$ & $\begin{array}{l}2,470 \\
4,580 \\
\end{array}$ & $\begin{array}{l}25,020 \\
30,880 \\
\end{array}$ & $\begin{array}{l}5,520 \\
6,390 \\
\end{array}$ & $\begin{array}{l}800 \\
820 \\
\end{array}$ & $\begin{array}{l}6,320 \\
7,210 \\
\end{array}$ \\
\hline & Total & 3,263 & 48,850 & 7,050 & 55,900 & 11,910 & 1,620 & 13,530 \\
\hline \multirow[t]{2}{*}{ B } & $\begin{array}{l}1 \\
2\end{array}$ & $\begin{array}{l}945 \\
863 \\
\end{array}$ & $\begin{array}{l}9,450 \\
8,630 \\
\end{array}$ & $\begin{array}{l}3,670 \\
6,460 \\
\end{array}$ & $\begin{array}{l}13,120 \\
15,090 \\
\end{array}$ & $\begin{array}{l}1,680 \\
1,450 \\
\end{array}$ & $\begin{array}{r}1,820 \\
750 \\
\end{array}$ & $\begin{array}{l}3,500 \\
2,200 \\
\end{array}$ \\
\hline & Total & 1,808 & 18,080 & 10,130 & 28,210 & $\overline{3,130}$ & $2, \overline{570}$ & $\overline{5,700}$ \\
\hline \multirow[t]{2}{*}{$\mathrm{D}$} & $\begin{array}{l}1 \\
2\end{array}$ & $\begin{array}{l}1,124 \\
2,100 \\
\end{array}$ & $\begin{array}{l}20,160 \\
37,520 \\
\end{array}$ & $\begin{array}{r}6,810 \\
810 \\
\end{array}$ & $\begin{array}{l}26,970 \\
33,330 \\
\end{array}$ & $\begin{array}{r}6,090 \\
12,140 \\
\end{array}$ & $\begin{array}{r}1,090 \\
350 \\
\end{array}$ & $\begin{array}{r}7,180 \\
12,490 \\
\end{array}$ \\
\hline & Total & $\overline{3,224}$ & 57,680 & $7 \overline{620}$ & $\overline{65,300}$ & 18,230 & 1,440 & 18,670 \\
\hline \multirow[t]{2}{*}{$\mathrm{E}$} & $\begin{array}{l}1 \\
2\end{array}$ & $\begin{array}{l}294 \\
\underline{275} \\
\end{array}$ & $\begin{array}{l}6,470 \\
5,860 \\
\end{array}$ & $\begin{array}{r}0 \\
2,010 \\
\end{array}$ & $\begin{array}{l}6,470 \\
7,870 \\
\end{array}$ & $\begin{array}{r}1,030 \\
930 \\
\end{array}$ & $\begin{array}{r}0 \\
530 \\
\end{array}$ & $\begin{array}{l}1,030 \\
1,460 \\
\end{array}$ \\
\hline & Total & $\overline{569}$ & 12,330 & $\overline{2,010}$ & $\overline{14,340}$ & $1, \overline{960}$ & $\overline{530}$ & 2,490 \\
\hline \multirow[t]{2}{*}{ G } & $\begin{array}{l}1 \\
2\end{array}$ & $\begin{array}{l}651 \\
505 \\
\end{array}$ & $\begin{array}{l}6,440 \\
3,260 \\
\end{array}$ & $\begin{array}{l}3,790 \\
2,790 \\
\end{array}$ & $\begin{array}{r}10,230 \\
6,050 \\
\end{array}$ & $\begin{array}{r}1,590 \\
570 \\
\end{array}$ & $\begin{array}{l}110 \\
990 \\
\end{array}$ & $\begin{array}{l}1,700 \\
1,560 \\
\end{array}$ \\
\hline & Total & $1, \overline{156}$ & 9,700 & 6,580 & 16,280 & 2,160 & 1,100 & 3,260 \\
\hline \multirow[t]{2}{*}{$\mathrm{H}$} & $\begin{array}{l}1 \\
2\end{array}$ & $\begin{array}{l}298 \\
643 \\
\end{array}$ & $\begin{array}{l}3,620 \\
8,560 \\
\end{array}$ & $\begin{array}{l}280 \\
\underline{840} \\
\end{array}$ & $\begin{array}{l}3,900 \\
9,400 \\
\end{array}$ & $\begin{array}{l}1,140 \\
2,680 \\
\end{array}$ & $\begin{array}{r}0 \\
170 \\
\end{array}$ & $\begin{array}{l}1,140 \\
2,850 \\
\end{array}$ \\
\hline & Total & 941 & 12,180 & 1,120 & 13,300 & 3,820 & 170 & 3,990 \\
\hline \multirow[t]{2}{*}{ I } & $\begin{array}{l}1 \\
2\end{array}$ & $\begin{array}{l}606 \\
807 \\
\end{array}$ & $\begin{array}{l}6,160 \\
8,640 \\
\end{array}$ & $\begin{array}{l}2,880 \\
2,670 \\
\end{array}$ & $\begin{array}{r}9,040 \\
11,310 \\
\end{array}$ & $\begin{array}{l}2,000 \\
2,530 \\
\end{array}$ & $\begin{array}{l}430 \\
140 \\
\end{array}$ & $\begin{array}{l}2,430 \\
2,670 \\
\end{array}$ \\
\hline & Total & 1,413 & 14,800 & 5,550 & 20,350 & 4,530 & 570 & 5,100 \\
\hline \multirow[t]{2}{*}{$\mathbf{J}$} & $\begin{array}{l}1 \\
2\end{array}$ & $\begin{array}{r}140 \\
\underline{25} \\
\end{array}$ & $\begin{array}{r}3,160 \\
\underline{500} \\
\end{array}$ & $\begin{array}{l}260 \\
340 \\
\end{array}$ & $\begin{array}{r}3,420 \\
\underline{840} \\
\end{array}$ & $\begin{array}{l}940 \\
150 \\
\end{array}$ & $\begin{array}{l}130 \\
160 \\
\end{array}$ & $\begin{array}{r}1,070 \\
\mathbf{3 1 0} \\
\end{array}$ \\
\hline & Total & $\overline{165}$ & $3, \overline{660}$ & 600 & 4,260 & 1,090 & 290 & 1,380 \\
\hline \multirow[t]{2}{*}{ L. } & $\begin{array}{l}1 \\
2\end{array}$ & $\begin{array}{l}286 \\
195 \\
\end{array}$ & $\begin{array}{r}3,810 \\
2,610 \\
\end{array}$ & $\begin{array}{l}1,480 \\
1,460 \\
\end{array}$ & $\begin{array}{l}5,290 \\
4,070 \\
\end{array}$ & $\begin{array}{r}1,200 \\
790 \\
\end{array}$ & $\begin{array}{r}440 \\
30 \\
\end{array}$ & $\begin{array}{r}1,640 \\
\underline{820} \\
\end{array}$ \\
\hline & Total & $\overline{481}$ & 6,420 & 2,940 & 9,360 & 1,990 & 470 & 2,460 \\
\hline \multirow[t]{2}{*}{$\mathbf{M}$} & $\begin{array}{l}1 \\
2\end{array}$ & $\begin{array}{l}752 \\
482 \\
\end{array}$ & $\begin{array}{l}7,880 \\
5,460 \\
\end{array}$ & $\begin{array}{l}850 \\
190 \\
\end{array}$ & $\begin{array}{l}8,730 \\
5,650 \\
\end{array}$ & $\begin{array}{r}1,770 \\
870 \\
\end{array}$ & $\begin{array}{l}430 \\
220 \\
\end{array}$ & $\begin{array}{l}2,200 \\
1,090 \\
\end{array}$ \\
\hline & Total & $1, \overline{234}$ & $\overline{13,340}$ & $1, \overline{040}$ & $\overline{14,380}$ & $2, \overline{640}$ & 650 & 3,290 \\
\hline \multirow[t]{2}{*}{$\mathbf{N}$} & $\begin{array}{l}1 \\
2\end{array}$ & $\begin{array}{r}148 \\
\underline{71}\end{array}$ & $\begin{array}{r}1,350 \\
330 \\
\end{array}$ & $\begin{array}{r}2,520 \\
460 \\
\end{array}$ & $\begin{array}{r}3,870 \\
790 \\
\end{array}$ & $\begin{array}{r}400 \\
60 \\
\end{array}$ & $\begin{array}{l}840 \\
820 \\
\end{array}$ & $\begin{array}{r}1,240 \\
880 \\
\end{array}$ \\
\hline & Total & $2 \overline{219}$ & $1, \overline{680}$ & $2, \overline{980}$ & $4, \overline{660}$ & 460 & 1,660 & 2,120 \\
\hline \multirow[t]{2}{*}{$\mathrm{O}$} & $\begin{array}{l}1 \\
2\end{array}$ & $\begin{array}{l}81 \\
59 \\
\end{array}$ & $\begin{array}{r}810 \\
1,000 \\
\end{array}$ & $\begin{array}{r}280 \\
1,310 \\
\end{array}$ & $\begin{array}{l}1,090 \\
2,310 \\
\end{array}$ & $\begin{array}{l}140 \\
180 \\
\end{array}$ & $\begin{array}{l}480 \\
430 \\
\end{array}$ & $\begin{array}{l}620 \\
610 \\
\end{array}$ \\
\hline & Total & $\overline{140}$ & $\overline{1,810}$ & $\overline{1,590}$ & $\overline{3,400}$ & $\overline{320}$ & 910 & $1,23 \theta$ \\
\hline \multirow[t]{2}{*}{$\mathrm{P}$} & $\begin{array}{l}1 \\
2\end{array}$ & $\begin{array}{l}231 \\
521 \\
\end{array}$ & $\begin{array}{l}1,410 \\
1,210 \\
\end{array}$ & $\begin{array}{l}530 \\
340 \\
\end{array}$ & $\begin{array}{l}1,940 \\
1,550 \\
\end{array}$ & $\begin{array}{l}440 \\
320 \\
\end{array}$ & $\begin{array}{l}110 \\
170 \\
\end{array}$ & $\begin{array}{l}550 \\
490 \\
\end{array}$ \\
\hline & Total & 752 & 2,620 & 870 & 3,490 & 760 & 280 & 1,040 \\
\hline \multirow[t]{2}{*}{$Q$} & $\begin{array}{l}1 \\
2\end{array}$ & $\begin{array}{l}0 \\
0 \\
\end{array}$ & $\begin{array}{l}0 \\
0 \\
\end{array}$ & $\begin{array}{l}210 \\
370 \\
\end{array}$ & $\begin{array}{l}210 \\
370 \\
\end{array}$ & $\begin{array}{l}0 \\
0 \\
\end{array}$ & $\begin{array}{l}370 \\
510 \\
\end{array}$ & $\begin{array}{l}370 \\
510 \\
\end{array}$ \\
\hline & Total & 0 & 0 & 580 & 580 & 0 & 880 & 880 \\
\hline $\begin{array}{l}\text { Totals } \\
\text { for all } \\
\text { farms }\end{array}$ & $\begin{array}{l}1 \\
2\end{array}$ & $\begin{array}{r}7,190 \\
8,175 \\
15,365\end{array}$ & $\begin{array}{r}93,270 \\
109,880 \\
203,150\end{array}$ & $\begin{array}{l}26,030 \\
24,630 \\
50,660\end{array}$ & $\begin{array}{l}119,300 \\
134,510 \\
253,810\end{array}$ & $\begin{array}{l}21,940 \\
29,060 \\
51,000\end{array}$ & $\begin{array}{r}7,050 \\
6,090 \\
13,140\end{array}$ & $\begin{array}{l}28,990 \\
35,150 \\
64,140\end{array}$ \\
\hline
\end{tabular}


Table 10 indicates that 1,000 tons more manure were applied during the second year of the study than during the first year in the Nutrient-Management Subbasin. Although nitrogen and phosphorus applications from commercial fertilizer were reduced by 15 and 18 percent, respectively, about 11 percent more nitrogen and 18 percent more phosphorus were applied during the second year. These increases were partially because of the application of manure reported earlier on September 5, 1985.

The methods of applying manure and the timing of applications affect the amount of nutrients that ultimately becomes available for the crops, surface runoff, or leaching to the ground water. If manure is simply applied to the surface, then a significant amount of the nitrogen can volatilize to the atmosphere in the form of ammonia. As much as 30 percent of the nitrogen can be lost by volatilization to the atmosphere within 7 days if the manure is not incorporated into the soil shortly after it is applied (Pennsylvania Department of Environmental Resources, 1986). Volatilization also will increase as air temperatures increase. Van Breemen and others (1982), however, suggest that substantial amounts of the nitrogen lost by volatilization can return to the soil surface in precipitation.

Approximately 18,000 tons of manure were produced annually on the farms in the NutrientManagement Subbasin during the 2 years of pre-BMP monitoring (table 7). About 7,190 tons of this manure in the first year and 8,175 tons in the second year were reported to have been spread on fields within the Nutrient-Management Subbasin (table 10). Another 3,900 tons of manure were estimated to have been deposited on pasture land annually by grazing animals. The remaining third of the manure, mostly from farms D and H (figure 3), was spread on fields outside the Nutrient-Management Subbasin.

\section{Soils and Nutrient Content}

The soils of the Small Watershed are noncarbonate, alluvial, or carbonate and are all fine to medium textured and well drained. The major noncarbonate soils are of the Brecknock, Bucks, and Unger series, whereas the minor noncarbonate soils are of the Manor, Chester, and Glenelg series. The alluvial soils of the Rowland and Readington series also were formed from noncarbonate residuum, but are greater than $20 \mathrm{in}$. deep and are located in the flood plains. The major carbonate soil series are Duffield and Hagerstown, and there are small areas of Clarksburg and Nolin series. Most of the carbonate soil series are cited as prime farm land in the Lancaster County Soil Survey (U.S. Department of Agriculture, 1985).

Soil maps from the Soil Survey were digitized to compare soils in the Small Watershed, the NutrientManagement Subbasin, and the Nonnutrient-Management Subbasin. The soils in the Small Watershed and those of the Nutrient-Management Subbasin are nearly the same; 47 and 50 percent are noncarbonate, 41 and 36 percent are carbonate, and 12 and 14 percent are alluvial, respectively. In the NonnutrientManagement Subbasin, 71 percent of the soils are noncarbonate, 18 percent carbonate, and 11 percent alluvial.

The soil pH of 40 fields on 10 farms in the Nutrient-Management Subbasin was measured between April 5-15, 1984. Soil pH ranged from 6.2 at a field at farm D (fig. 3) to 7.3 at a field at farm E. The average $\mathrm{pH}$ for the 10 farms, calculated as the mean of the hydrogen-ion concentrations, ranged from 6.5 to 7.2.

Available nitrogen (nitrate) and phosphorus concentrations of soils from seven fields were measured after the growing seasons in 1984 and 1985 (figs. 6 and 7). These concentrations reflect only the amount of nitrate nitrogen. They do not account for nitrogen from ammonia or nitrogen that may become available from nitrification of residual organic nitrogen in the soil. The total amount of nitrate-nitrogen in the top $4 \mathrm{ft}$ of soil ranged from 45 to $372 \mathrm{lb} /$ acre (pounds per acre). At some fields, nitrate concentrations at the $36-48$ in. depth were about the same or greater than the concentrations in the top 8 in. reflecting the highly soluble nature of nitrate. The nitrate concentrations in the soil at some fields may even be greater below $4 \mathrm{ft}$. Soil-nitrate concentrations increased from 63 to $161 \mathrm{lb} /$ acre and 225 to $372 \mathrm{lb} /$ acre at farms I and F, respectively, from 1984 to 1985; at the other 5 sites, concentrations decreased. The cause for the increases was not determined; however, one possible cause may be that seepage from manure piles not spread evenly on the fields may percolate through the $4-\mathrm{ft}$ root zone of the soil column. Nitrogen in soil is organically bound as humus, and inorganically present as nitrate $\left(\mathrm{NO}_{3}{ }^{+}\right)$and ammonium $\left(\mathrm{NH}_{4}{ }^{+}\right)$ions. About 99 percent of the total soil nitrogen is in the organic form and is not appreciably absorbed by most 
plants. Some plants, such as alfalfa, which is a legume, can use nitrogen from the atmosphere, but nitrate is the ion that is used by most plants. The highly mobile nitrate ion is made available to solution from manure and fertilizers and the conversion of the organic and ammonia nitrogen to the nitrate ion. When the nitrate ion is present in porous soils in greater quantities than required for optimum plant growth, the nitrate ion can leach downward from the porous surface soil layer into the deeper subsurface soils.

Soil monitoring studies in Nebraska, Iowa, and Wisconsin (Hallberg and others, 1984; Rehm, Zoubek, and Hoorman, 1983) suggest that less than $100 \mathrm{lb} /$ acre of nitrate nitrogen should remain in the top $4 \mathrm{ft}$ of soil so that leachate to the ground water will never exceed $20 \mathrm{mg} / \mathrm{L}$ nitrate nitrogen. Baker (Pennsylvania State University, College of Agriculture, Department of Agronomy, written commun., 1985) states that a more desirable environmental level for nitrate-nitrogen may be $50 \mathrm{lb} /$ acre in the upper $4 \mathrm{ft}$ of soil. Nitratenitrogen concentrations in soils at all of the farms (fig. 6) in the fall of 1984 and six of the farms in the fall of 1985 exceeded the value recommended by Baker.

Crop management can affect the nutrient content of soil. Corn and alfalfa, the major crops grown in the study area, have different nitrogen requirements. Corn utilizes large amounts of nitrogen that are added to soil through manure and commercial fertilizer applications, whereas alfalfa adds nitrogen to the soil. The Penn State Agronomy Guide (1987-88, p.23) indicates that the first year after an average stand of alfalfa is plowed under, about $80 \mathrm{lb} /$ acre of nitrogen becomes available in the soil for crop production. This is especially true when soil temperatures exceed $50^{\circ} \mathrm{F}$ (degrees Fahrenheit) and the active nitrifying bacteria accelerate the release of soluble nitrogen. Therefore, on the basis of the reported crop rotation for 1985 and the assumption that the alfalfa stands in the Nutrient-Management Subbasin were average stands, it was calculated that about 7,120 lb of nitrogen were made available for crops or for leaching to ground water from the 89 acres of alfalfa when it was plowed into the soil. Thus, about 5 percent of the nitrogen input to cropland in the Nutrient-Management Subbasin was from alfalfa (126,905 lb from table 9 plus $7,120 \mathrm{lb}$ from alfalfa). This is comparable to the 8 to 10 percent contribution of nitrogen by legumes, such as alfalfa, to cropland in the Big Spring Basin in lowa reported by Hallberg (1987, p.52).

Farmers in the Small Watershed generally follow the SCS recommendation that plowing, and therefore, rotation of alfalfa to corn, be done in the spring. This practice helps to reduce soil loss in the fall and winter when it may be difficult to establish cover crops, and it also improves utilization of the nitrogen for corn production, thereby reducing the leaching of nitrogen to the ground water.

The total amount of phosphorus in the top $4 \mathrm{ft}$ of soil ranged from 1.4 to $23 \mathrm{lb} / \mathrm{acre}$. In contrast to the nitrate concentrations, phosphorus concentrations were consistently greater in the top 8 in. of the soil reflecting the affinity that phosphorus has for fine soil particles. Phosphorus concentrations increased at farm G from 2.4 to $5.4 \mathrm{lb}$ /acre from 1984 to 1985; at the other six sites, the concentrations remained the same or decreased. Most of the phosphorus in the soil in the Nutrient-Management Subbasin may be available for the crops inasmuch as the optimum range of $\mathrm{pH}$ for phosphorus availability is 6.5 to 7.0 . At a high or low $\mathrm{pH}$, phosphorus can form insoluble compounds with iron or aluminum and become unavailable to plants. 

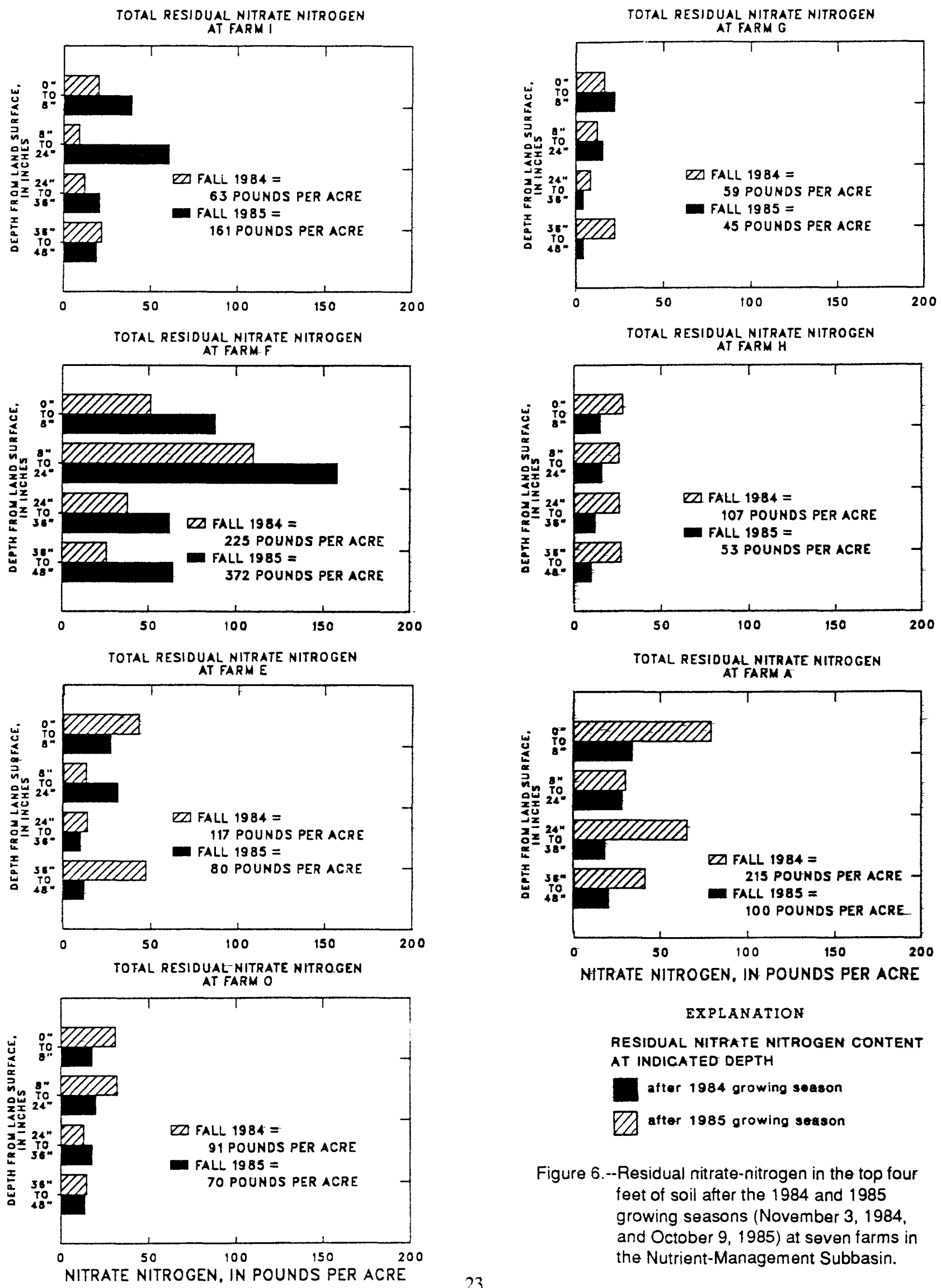

EXPLANATION

RESIDUAL NITAATE NITROGEN CONTENT AT INDICATED DEPTH

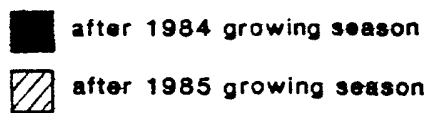

Figure 6.--Residual nitrate-nitrogen in the top four feet of soil after the 1984 and 1985 growing seasons (November 3, 1984, and October 9,1985 ) at seven farms in the Nutrient-Management Subbasin. 

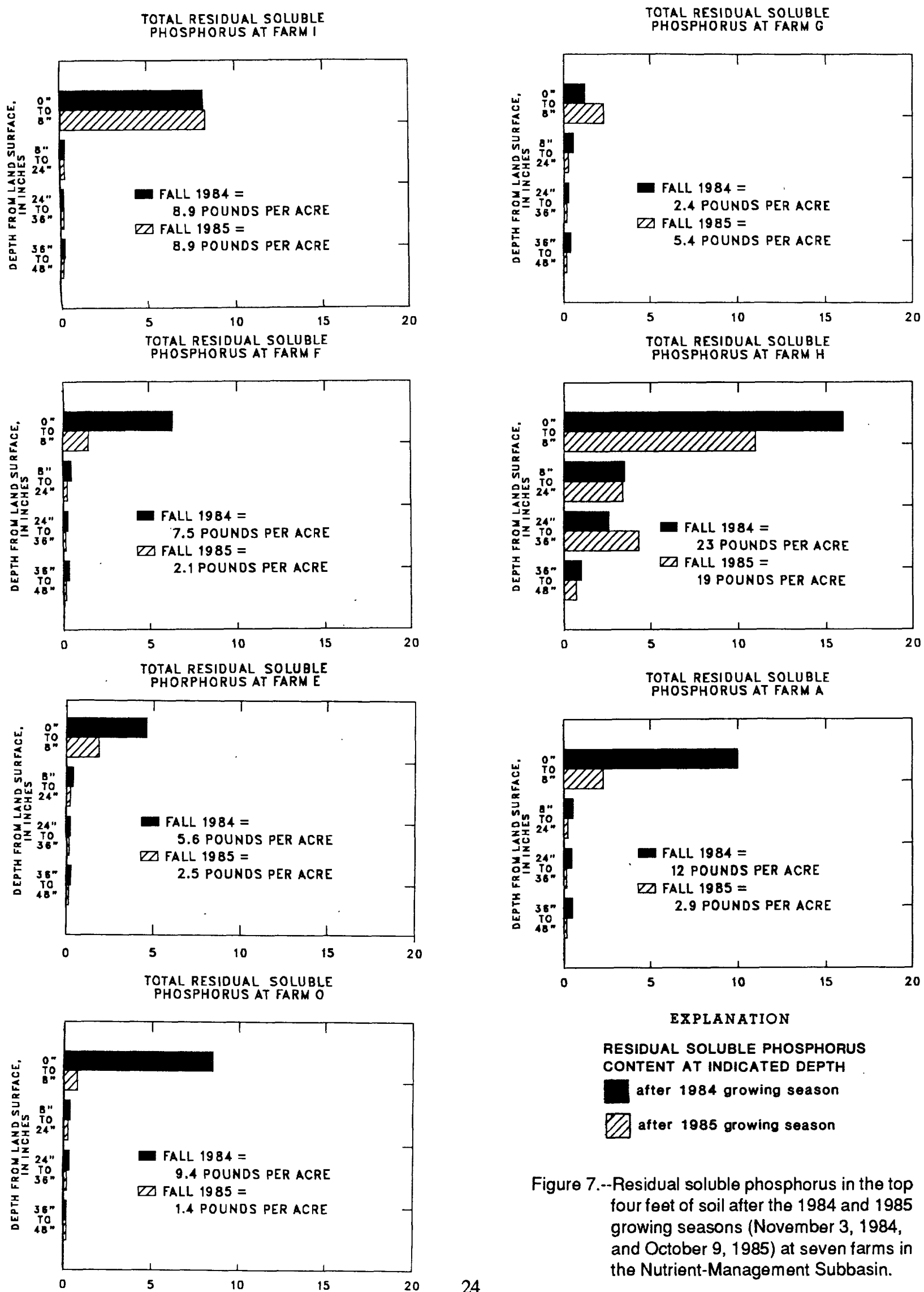

RESIDUAL SOLUBLE PHOSPHORUS CONTENT AT INDICATED DEPTH

after 1884 growing season

Dafter 1985 growing season

Figure 7.--Residual soluble phosphorus in the top four feet of soil after the 1984 and 1985 growing seasons (November 3, 1984, and October 9,1985 ) at seven farms in the Nutrient-Management Subbasin. 


\section{Streamflow}

Streamflow data collected in the Small Watershed were compared to the 55 years of record for the gage at the Conestoga River at Lancaster (USGS station no. 01576500), which is $16.75 \mathrm{mi}$ southwest (28.2 river miles downstream) of the study area. Streamflows at the Small Watershed for the first year (April 1984 through March 1985) of the study were not well related to those at Lancaster because 8 in. less precipitation was recorded at the Small Watershed than at Lancaster. Streamflows during the second year (April 1985 through March 1986) of the study were about 15 percent lower than normal at the Small Watershed since the amounts of precipitation at the Small Watershed and Lancaster were similar, and the streamflows at Lancaster were 15 percent below the long-term mean. Streamflow was about 36 percent greater during the first year than during the second year at the Small Watershed, and streamflow was 4 percent greater during the first year than during the second year at the Nutrient-Management Subbasin.

Mean daily streamflow at the Small Watershed ranged from $0.76 \mathrm{ft}^{3} / \mathrm{s}$ (cubic feet per second) on September 20 and 21,1985, to $165 \mathrm{ft}^{3} / \mathrm{s}$ on July 7,1984 . The annual average streamflows at the Small Watershed were 7.57 and $5.55 \mathrm{ft}^{3} / \mathrm{s}$ for the first and second year of the study, respectively. Mean daily streamflow at the Nutrient-Management Subbasin ranged from $0.06 \mathrm{ft}^{3} / \mathrm{s}$ on January 21 and 22, 1985, to $41 \mathrm{ft}^{3} / \mathrm{s}$ on September 27, 1985. Annual average streamflows at the Nutrient-Management Subbasin were 1.28 and $1.23 \mathrm{ft}^{3} / \mathrm{s}$ for the 2 years of the pre-BMP phase, respectively.

Hydrograph separations of the continuous streamflow data from the Small Watershed and the Nutrient-Management Subbasin indicate that the streamflow characteristics of the two sites are similar (fig. 8). Surface runoff increased in streamflow within a few hours after precipitation began at both sites.

Table 11 lists the monthly contribution of base flow of the Small Watershed and the NutrientManagement Subbasin. Total streamflow and base flow are expressed in the table as inches of runoff. Runoff is the depth to which the drainage area would be covered if all the streamflow for a given time period were distributed uniformly on it. Base flow comprised from 9 to 96 percent of the monthly streamflow, the percentage depending on the amount of precipitation and storm intensities. The monthly percentages of base flow were usually similar at the sites. Similarities in streamflow characteristics at the sites were probably because both sites lie within the carbonate-rock floored valley, have similar waterbearing formations, and are only $3.3 \mathrm{mi}$ apart. The large differences in the monthly percentage of base flow between the sites in May 1985 were likely the result of local storms.

Total runoff from the Small Watershed during the pre-BMP phase was 30.59 in., of which 17.43 in. (56 percent) was base flow. Total runoff from the Nutrient-Management Subbasin was about $25.25 \mathrm{in}$., of which 15.26 in. (60 percent) was base flow. About 20 percent of the flow at Site 5 was from Site 3A.

About 74 and 79 percent of the streamflow at the Small Watershed and the Nutrient-Management Subbasin, respectively, occurred in the growing season (April through September) during the first year of the study. About 30 and 28 percent of the streamflow at the Small Watershed and the NutrientManagement Subbasin, respectively, occurred in the growing season during the second year of the study. 

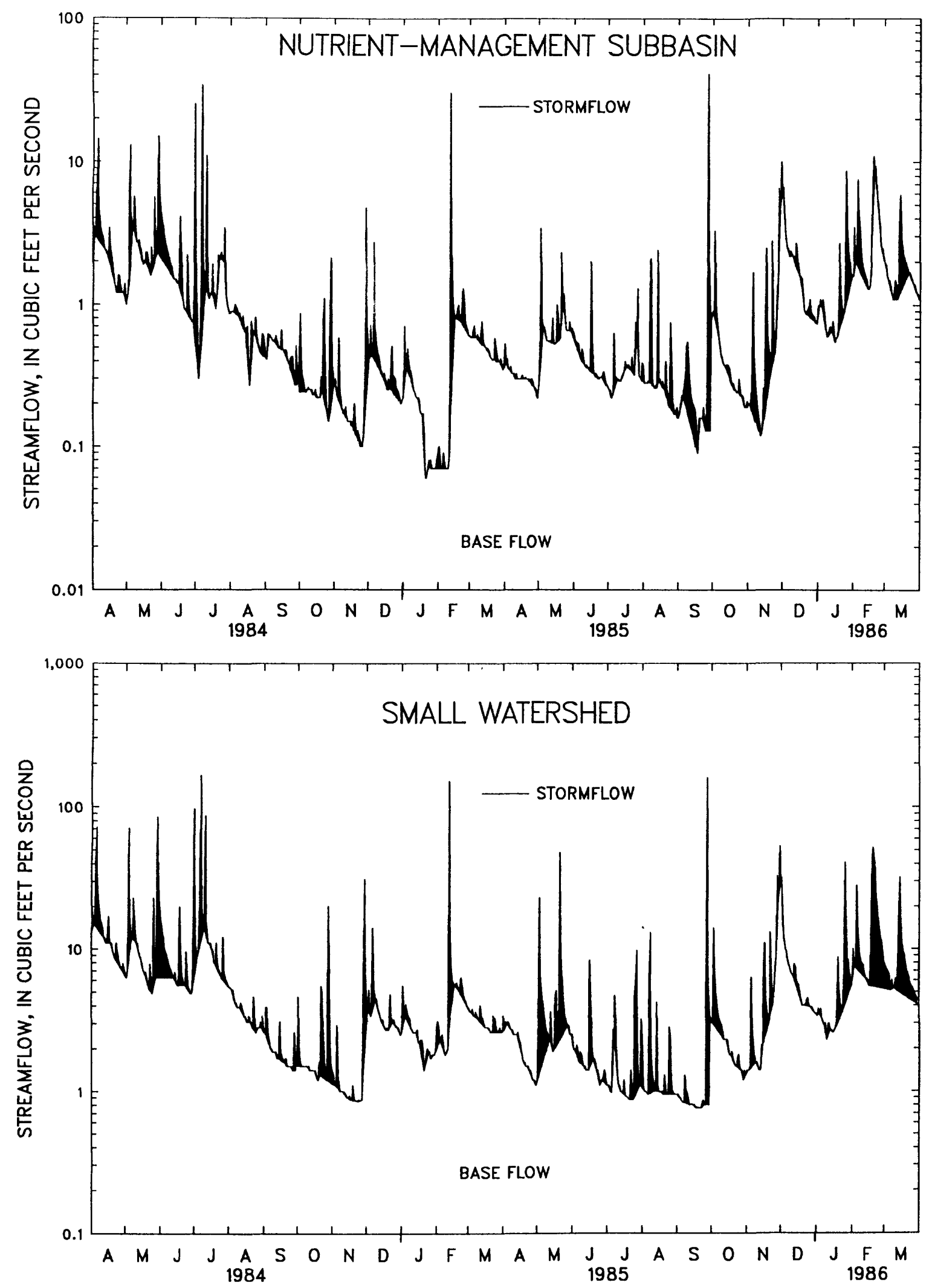

Figure 8.--Surface runoff and base flow components of total streamflow at the Nutrient-Management Subbasin and the Small Watershed, April 1, 1984, through March 31, 1986. 
Table 11.-Total streamflow and base-flow contributions at the Small Watershed and the Nutrient-Management Subbasin during the pre-Best-Management Practice phase, April 1, 1984 through March 31,1986

[Streamflow and base flow of runoff, in inches]

\begin{tabular}{|c|c|c|c|c|c|c|c|}
\hline \multirow[b]{2}{*}{ Month } & \multirow[b]{2}{*}{ Year } & \multicolumn{3}{|c|}{ Small Watershed } & \multicolumn{3}{|c|}{ Nutrient-Management Subbasin } \\
\hline & & $\begin{array}{c}\text { Total } \\
\text { streamflow }\end{array}$ & $\begin{array}{l}\text { Base } \\
\text { flow }\end{array}$ & $\begin{array}{l}\text { Percentage of } \\
\text { base flow } \\
\text { in total } \\
\text { streamflow }\end{array}$ & $\begin{array}{c}\text { Total } \\
\text { streamflow }\end{array}$ & $\begin{array}{l}\text { Base } \\
\text { flow }\end{array}$ & $\begin{array}{l}\text { Percentage of } \\
\text { base flow } \\
\text { in total } \\
\text { streamflow }\end{array}$ \\
\hline April & $\begin{array}{l}1984 \\
1985\end{array}$ & $\begin{array}{r}2.92 \\
.41\end{array}$ & $\begin{array}{r}2.08 \\
39\end{array}$ & $\begin{array}{l}71 \\
96\end{array}$ & $\begin{array}{r}2.27 \\
28\end{array}$ & $\begin{array}{r}1.51 \\
27\end{array}$ & $\begin{array}{l}66 \\
95\end{array}$ \\
\hline May & $\begin{array}{l}1984 \\
1985\end{array}$ & $\begin{array}{l}3.15 \\
1.12\end{array}$ & $\begin{array}{r}1.53 \\
.42\end{array}$ & $\begin{array}{l}48 \\
37\end{array}$ & $\begin{array}{r}3.01 \\
.65\end{array}$ & $\begin{array}{r}1.72 \\
.47\end{array}$ & $\begin{array}{l}57 \\
72\end{array}$ \\
\hline June & $\begin{array}{l}1984 \\
1985\end{array}$ & $\begin{array}{r}1.62 \\
37\end{array}$ & $\begin{array}{r}1.12 \\
29\end{array}$ & $\begin{array}{l}69 \\
79\end{array}$ & $\begin{array}{r}1.49 \\
36\end{array}$ & $\begin{array}{r}1.04 \\
30\end{array}$ & $\begin{array}{l}70 \\
82\end{array}$ \\
\hline July & $\begin{array}{l}1984 \\
1985\end{array}$ & $\begin{array}{r}4.16 \\
39\end{array}$ & $\begin{array}{r}1.76 \\
.23\end{array}$ & $\begin{array}{l}42 \\
59\end{array}$ & $\begin{array}{r}2.93 \\
.32\end{array}$ & $\begin{array}{l}.92 \\
.27\end{array}$ & $\begin{array}{l}31 \\
84\end{array}$ \\
\hline August & $\begin{array}{l}1984 \\
1985\end{array}$ & $\begin{array}{l}.75 \\
.37\end{array}$ & $\begin{array}{l}.71 \\
.19\end{array}$ & $\begin{array}{l}95 \\
52\end{array}$ & $\begin{array}{l}.57 \\
38\end{array}$ & $\begin{array}{l}.50 \\
.20\end{array}$ & $\begin{array}{l}88 \\
52\end{array}$ \\
\hline September & $\begin{array}{l}1984 \\
1985\end{array}$ & $\begin{array}{r}.39 \\
1.26\end{array}$ & $\begin{array}{l}.34 \\
.16\end{array}$ & $\begin{array}{l}87 \\
12\end{array}$ & $\begin{array}{r}.37 \\
1.33\end{array}$ & $\begin{array}{l}.34 \\
.11\end{array}$ & $\begin{array}{r}91 \\
9\end{array}$ \\
\hline October & $\begin{array}{l}1984 \\
1985\end{array}$ & $\begin{array}{l}.54 \\
.55\end{array}$ & $\begin{array}{l}27 \\
.40\end{array}$ & $\begin{array}{r}49 \\
7327\end{array}$ & $\begin{array}{l}.34 \\
.40\end{array}$ & $\begin{array}{l}.18 \\
.31\end{array}$ & $\begin{array}{l}53 \\
78\end{array}$ \\
\hline November & $\begin{array}{l}1984 \\
1985\end{array}$ & $\begin{array}{r}.47 \\
1.39\end{array}$ & $\begin{array}{l}20 \\
.86\end{array}$ & $\begin{array}{l}43 \\
62\end{array}$ & $\begin{array}{r}28 \\
1.03\end{array}$ & $\begin{array}{l}.13 \\
.55\end{array}$ & $\begin{array}{l}46 \\
53\end{array}$ \\
\hline December & $\begin{array}{l}1984 \\
1985\end{array}$ & $\begin{array}{r}.77 \\
1.55\end{array}$ & $\begin{array}{r}.64 \\
1.47\end{array}$ & $\begin{array}{l}82 \\
95\end{array}$ & $\begin{array}{r}36 \\
1.61\end{array}$ & $\begin{array}{r}24 \\
1.48\end{array}$ & $\begin{array}{l}68 \\
92\end{array}$ \\
\hline January & $\begin{array}{l}1985 \\
1986\end{array}$ & $\begin{array}{r}.51 \\
1.13\end{array}$ & $\begin{array}{l}.46 \\
.66\end{array}$ & $\begin{array}{l}90 \\
58\end{array}$ & $\begin{array}{r}.17 \\
1.15\end{array}$ & $\begin{array}{l}.15 \\
.69\end{array}$ & $\begin{array}{l}85 \\
60\end{array}$ \\
\hline February & $\begin{array}{l}1985 \\
1986\end{array}$ & $\begin{array}{l}1.75 \\
2.81\end{array}$ & $\begin{array}{r}.63 \\
1.08\end{array}$ & $\begin{array}{l}36 \\
38\end{array}$ & $\begin{array}{l}1.25 \\
2.76\end{array}$ & $\begin{array}{r}29 \\
2.06\end{array}$ & $\begin{array}{l}24 \\
75\end{array}$ \\
\hline March & $\begin{array}{l}1985 \\
1986\end{array}$ & $\begin{array}{r}.62 \\
1.59\end{array}$ & $\begin{array}{l}.59 \\
.95\end{array}$ & $\begin{array}{l}94 \\
59\end{array}$ & $\begin{array}{r}.44 \\
1.50\end{array}$ & $\begin{array}{r}.42 \\
1.11\end{array}$ & $\begin{array}{l}95 \\
74\end{array}$ \\
\hline Totals & $\begin{array}{l}\text { Year } 1 \\
\text { Year } 2\end{array}$ & $\begin{array}{l}17.65 \\
12.94 \\
\end{array}$ & $\begin{array}{r}10.33 \\
7.10 \\
\end{array}$ & $\begin{array}{l}59 \\
55 \\
\end{array}$ & $\begin{array}{l}13.48 \\
11.77 \\
\end{array}$ & $\begin{array}{l}7.44 \\
7.82 \\
\end{array}$ & $\begin{array}{l}55 \\
66 \\
\end{array}$ \\
\hline pre- & P phase & 30.59 & 17.43 & 57 & 25.25 & 15.26 & 60 \\
\hline
\end{tabular}




\title{
WATER-QUALITY CHARACTERIZATION
}

\author{
Surface Water \\ Base Flow
}

The median dissolved nitrite plus nitrate-nitrogen concentration in base flow at Site 1 in the nonagricultural, noncarbonate area of the Nutrient-Management Subbasin was $2.7 \mathrm{mg} / \mathrm{L}$ during the 2-year study (table 12). Median dissolved nitrate-nitrogen concentrations increased to $8.1 \mathrm{mg} / \mathrm{L}$ as the water flowed through the intensively farmed carbonate-rock floored valley at Site $3 \mathrm{~A}$, the most downstream site in the Nutrient-Management Subbasin. The median dissolved nitrite plus nitratenitrogen concentration at Site 5, the most downstream site in the Small Watershed, was $7.0 \mathrm{mg} / \mathrm{L}$. Median total-phosphorus concentrations increased from $0.05 \mathrm{mg} / \mathrm{L}$ at Site 1 to $0.20 \mathrm{mg} / \mathrm{L}$ at Site $2 \mathrm{~A}$ in the agricultural, carbonate area and then decreased to $0.18 \mathrm{mg} / \mathrm{L}$ at Site $3 \mathrm{~A}$, reflecting the deposition of sediment that was observed between Sites $2 \mathrm{~A}$ and Site $3 \mathrm{~A}$ when sampling base flow. At Site $2 \mathrm{~A}$, the streamflow changes from southward to westward (fig. 1), and the stream velocity begins to decrease causing sediment deposition near the bridge immediately downstream from Site $2 \mathrm{~A}$. The median totalphosphorus concentrations were about the same at all of the agricultural, carbonate sites-from 0.18 to $0.23 \mathrm{mg} / \mathrm{L}$. Variations in nutrient concentrations and loads were greater in the agricultural, carbonate area (Sites $2 \mathrm{~A}, 3 \mathrm{~A}, 9$, and 5) than in the most upstream site (Site 1) in the nonagricultural, noncarbonate area (table 12 and figs. 9-10).

Time-series plots (figs. 11 to 17) of precipitation, nutrient applications, and concentrations and loads of total nitrogen, dissolved nitrite plus nitrate nitrogen, and total and dissolved phosphorus at Sites 1, 3A, and 5 show the relations between these variables and base flow during growing and nongrowing seasons. Concentrations of dissolved nitrite plus nitrate nitrogen were greater following wet periods after crops were harvested and manure was applied. For example, in September 1985 when Hurricane Gloria produced $5.4 \mathrm{in}$. of precipitation shortly after crops were removed and about 1,150 tons of manure were applied to a 7.5-acre pasture on farm D-a substantial increase in the concentrations of dissolved nitrite plus nitrate nitrogen was noted at Sites $3 \mathrm{~A}$ and 5 (figs. 13 and 16).

Concentrations of dissolved nitrite plus nitrate nitrogen in base flow decreased more during the second growing season than during the first growing season at Sites $3 \mathrm{~A}$ and 5 (figs. 13 and 16). Decreases in concentrations were greater when precipitation, infiltration, and recharge to the ground water decreased (January 1985 through April 1985) and nutrient utilization and evapotranspiration by crops increased (May 1985 through September 1985). Nitrite plus nitrate-nitrogen concentrations were comparatively low during nonrecharge periods when the ground water that discharged as base flow was in little contact with the soil but in prolonged contact with the carbonate rock. Dissolved-nitrite plus nitrate nitrogen concentrations decreased from 7.6 to $3.9 \mathrm{mg} / \mathrm{L}$, and specific conductance increased from 275 to $390 \mu \mathrm{S} / \mathrm{cm}$ (microsiemens per centimeter at 25 degrees Celsius) at Site $3 \mathrm{~A}$ from April through August 1985. The minimum dissolved-nitrite plus nitrate nitrogen concentration in base flow of $3.9 \mathrm{mg} / \mathrm{L}$ on August 20,1985, at Site 3A suggests that water quality is better when base flow discharges from the lower ground-water zone than it is when base flow, discharges from the upper ground-water zone. During periods when the ground-water table was low (in late summer and early fall) the ground water had little contact time with the nutrient-rich soils, so the nitrate concentration in the ground water was probably lower than when the ground-water table was high. When base flow is low, it is sustained primarily by discharges of ground water that had percolated vertically through the soil column to the lower groundwater zone within the carbonate rock and then discharged through the streambed. This ground water had a short period of contact with the soil. This is reflected by the decreases in nitrite plus nitrate-nitrogen concentrations and increases in specific conductance, especially at Site 3A. In contrast, when base flow is high, it is sustained by lateral discharges of ground water, some of which is interflow, that have migrated horizontally for longer time periods through the nutrient-rich soils. 
discharged at the rate of $16\left(\right.$ tons $\left./ \mathrm{mi}^{2}\right) / \mathrm{yr}$ in base flow from Site $3 \mathrm{~A}$. Like the nutrients, most of the sediment load in base flow was transported during high base flow. Over 1.8 times more sediment was discharged from Site 3A during the first year than during the second year. Most of the suspendedsediment load in base flow during the first year was transported by high base flows in May and June. The high base flows were the result of storms which carried sediment to the streams shortly after fields were plowed.

Pesticide samples were collected during the growing seasons of the pre-BMP phase. Atrazine and simazine, herbicides commonly used for weed control in corn fields, were detected in base flow at Site 1 in the nonagricultural, noncarbonate area during the first year of the study (table 12). Field reconnaissance revealed that used pesticide containers were throughout the wooded area upstream from the site. Pesticides were not detected at Site 1 after the landowner was notified by PaDER to dispose of the used containers in an approved manner (table 14). However, these results are not conclusive because the detection limit for atrazine increased from $0.10 \mu \mathrm{g} / \mathrm{L}$ (micrograms per liter) to $0.20 \mu \mathrm{g} / \mathrm{L}$ after the disposal area was identified. 
Nitrite plus nitrate nitrogen concentrations and loads probably varied greatly throughout the year in the Nutrient-Management Subbasin because of the intensity of agriculture and the interaction with the timing of precipitation. For example, commercial applications of nitrogen were decreased by 5 percent in the second year, thereby making less nitrate available for transport to the stream. Secondly, because 52 percent of the total acreage was planted in corn, large amounts of nitrate were required for crop production; most of this nitrate was removed when the crop was harvested. Lastly, evapotranspiration, increased substantially in the subbasin as the corn grew. As evapotranspiration increased, proportionally less water percolated to carry nitrate to the ground water, which could discharge later as base flow.

Unlike dissolved-nitrite plus nitrate nitrogen concentrations, total-phosphorus concentrations in base flow at Site $3 \mathrm{~A}$ increased during the pre-BMP phase and were greatest near the end of the growing season (fig. 14). This pattern may have been caused by the large amounts of soluble phosphorus applied late in the growing season as commercial fertilizer to alfalfa fields that were deficient in phosphorus. Excess phosphorus from this application was probably transported to the stream in stormflow, absorbed by fine sediments, and deposited on the stream bottom. Phosphorus redissolves when anaerobic conditions develop. Masses of tubifex worms were found in the streambed material at Site $2 \mathrm{~A}$; these worms thrive in poorly oxygenated water, suggesting that the water was anaerobic at Site $2 \mathrm{~A}$ during June, July, and August of each year. Another cause for increases in phosphorus during warmer months was that cattle deposit manure rich in phosphorus directly into the stream at Sites 2A and 3A. Phosphorus also is released to the stream from the decomposition of algal blooms and other aquatic vegetation. Finally, base flow decreased at the end of the growing season; therefore, dilution of the phosphorus decreased at this time.

At the Paired-Watersheds, the median dissolved-nitrite plus nitrate nitrogen concentration in base flow was greater at Site 3A (Nutrient-Management Subbasin) than at Site 9 (Nonnutrient-Management Subbasin), and median concentrations of total phosphorus and total-ammonia plus organic nitrogen were generally greater at Site 9 than at Site 3A (table 12). Less dilution of dissolved nitrite plus nitrate nitrogen and greater deposition of suspended phosphorus and suspended ammonia plus organic nitrogen occurred at Site $3 \mathrm{~A}$ than at Site 9 because of comparatively lower streamflows and slower stream velocities at Site 3A. Correlations between nutrient concentrations and nutrient loads at Sites $3 \mathrm{~A}$ and 9 were poor $(\mathrm{r}<0.80)$ except for the loads of dissolved nitrite plus nitrate nitrogen $(r=0.92)$ (figs. 18 and 19). These poor correlations suggest that the availability of nutrients for transport at the Paired-Watersheds or the factors controlling the transport of the nutrients, such as land-use practices and precipitation, may be different at the two sites.

Further examination of the data in figure 18 indicates that dissolved-nitrite plus nitrate nitrogen concentrations in base flow at both subbasins are affected by precipitation. This was exemplified when base-flow concentrations increased from 7.5 to $10 \mathrm{mg} / \mathrm{L}$ at Site $3 \mathrm{~A}$ and from 2.2 to $5.7 \mathrm{mg} / \mathrm{L}$ at Site 9 following Hurricane Gloria in September 1985.

Monthly nutrient and suspended-sediment loads in base flow at Sites $3 \mathrm{~A}$ and 5 during the pre-BMP phase are listed in table 13. The nitrogen, phosphorus, and suspended-sediment loads were greater during high base flow than during low base flow. Annual nitrogen and phosphorus loads for Sites $3 \mathrm{~A}$ and 5 were about the same both years; however, there were large differences between months. During the 2 years, nearly $162,000 \mathrm{lb}$ ( 81 tons) of nitrogen were discharged at the rate of 7.0 (tons $/ \mathrm{mi}^{2}$ ) $/ \mathrm{yr}$ (tons per square mile per year) in base flow at Site 5 during the pre-BMP phase, and nearly 32,000 lb (16 tons) of the nitrogen were discharged at the rate of $5.5\left(\right.$ tons $\left./ \mathrm{mi}^{2}\right) / \mathrm{yr}$ at Site $3 \mathrm{~A}$. Most of the nitrogen load was composed of dissolved nitrite plus nitrate nitrogen and was discharged during months of high base flow. About 2,900 lb (1.45 tons) of phosphorus were discharged at the rate of $0.12\left(\mathrm{ton} / \mathrm{mi}^{2}\right) / \mathrm{yr}$ in base flow at Site 5 and about $536 \mathrm{lb}(0.268 \mathrm{ton})$ were discharged at the rate of $0.10\left(\right.$ ton $\left./ \mathrm{mi}^{2}\right) / \mathrm{yr}$ at Site $3 \mathrm{~A}$.

Nearly $576,000 \mathrm{lb}$ (288 tons) of suspended sediment were discharged at the rate of 24 (tons $/ \mathrm{mi}^{2}$ ) $/ \mathrm{yr}$ in base flow at Site 5 during the pre-BMP phase. About $90,500 \mathrm{lb}$ (45.25 tons) of the suspended sediment were 

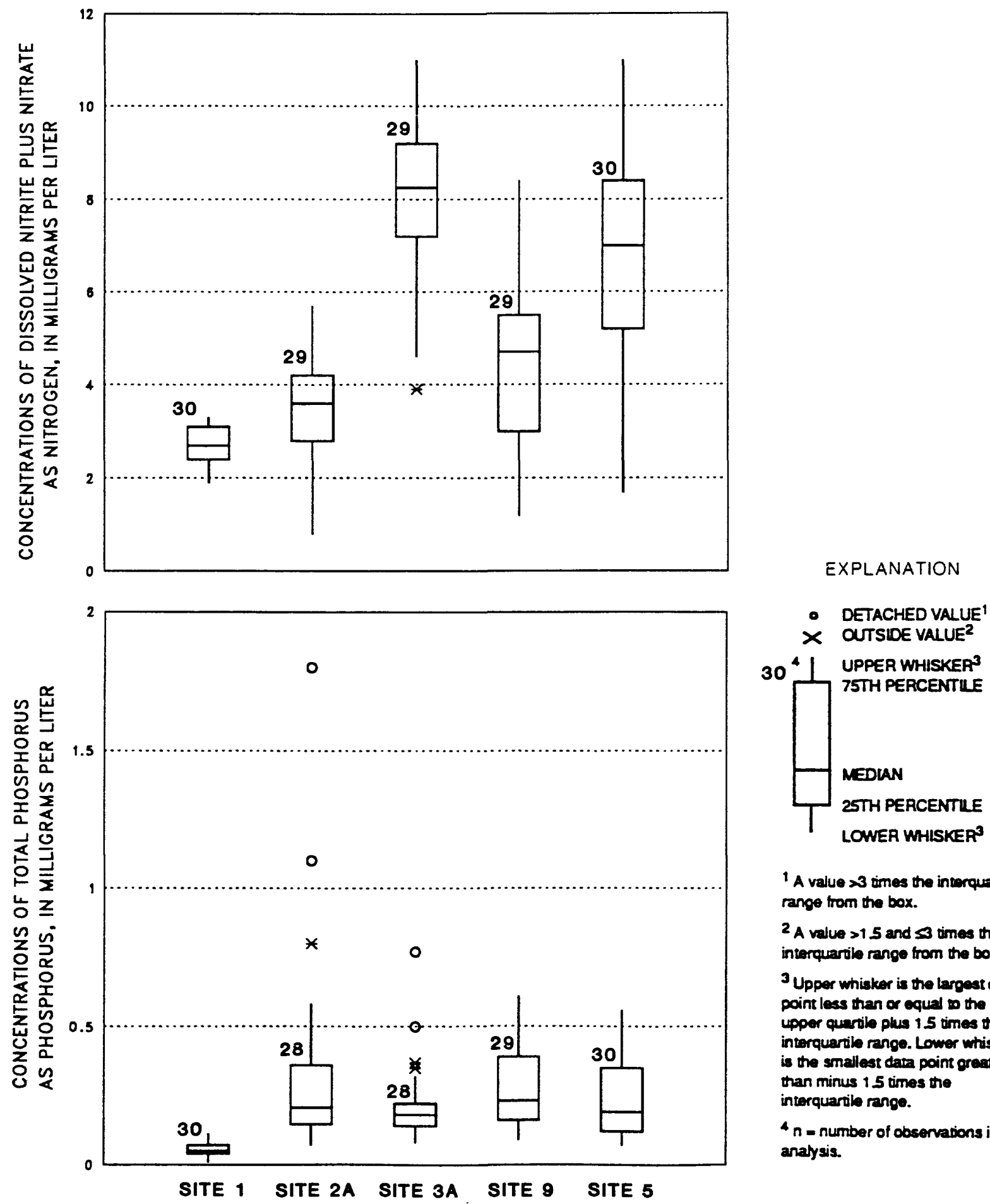

${ }^{1}$ A value $>3$ imes the interquarile range from the box.

$2 A$ value $>15$ and $\leq 3$ times the interquarib range from the box.

3 Upper whisker is the largest data point less than or equal to the upper quartile plus 15 times the interquartile range. Lower whisher is the smallest dam point greater than minus 15 times the interquartile range.

$4 n=$ number of observations in analysis.

Figure 9.-Concentrations of dissolved nitrite plus nitrate as nitrogen and total phosphorus as phosphorus at surface-water sites during pre-Best-Management Practice phase, April 1, 1984, through March 31, 1986. 
Table 12-Water-quality characteristics of base flow in the Small Watershed,

April 1, 1984 through March 31, 1986 (pre-Best-Management Practice period data)

[Conc, concentration in milligrams per liter; load, load in pounds per day; $n$, number of values;

N, nitrogen; P, phosphorus; Min, minimum; Max, maximum; $\mathrm{ft}^{3} / \mathrm{s}$, cubic feet per second; <, less than;

-, sample not analyzed for indicated constituent]

\begin{tabular}{|c|c|c|c|c|c|c|}
\hline \multirow{2}{*}{$\begin{array}{l}\text { Character- } \\
\text { istic or } \\
\text { constituent }\end{array}$} & \multirow[b]{2}{*}{ Statistic } & \multirow{2}{*}{$\begin{array}{c}\text { Nonagricultural, } \\
\text { noncarbonate }\end{array}$} & \multicolumn{4}{|c|}{ Agricultural, carbonate area } \\
\hline & & & Site 2A & Site 3A & Site 9 & Site 5 \\
\hline $\begin{array}{l}\text { Streamflow } \\
\left(\mathrm{ft}^{3} / \mathrm{s}\right)\end{array}$ & $\begin{array}{l}\text { Median } \\
\text { n } \\
\text { Min } \\
\text { Max }\end{array}$ & $\begin{array}{l}0.21 \\
30 \\
.06 \\
1.3\end{array}$ & $\begin{array}{l}0.29 \\
28 \\
.06 \\
1.7\end{array}$ & $\begin{array}{l}0.63 \\
29 \\
.12 \\
2.7\end{array}$ & $\begin{array}{l}0.95 \\
29 \\
26 \\
5.0\end{array}$ & $\begin{array}{l}3.2 \\
30 \\
.81 \\
15\end{array}$ \\
\hline \multirow[t]{2}{*}{$\begin{array}{l}\text { Nitrite + } \\
\text { nitrate, } \\
\text { total } \\
\text { as } \mathrm{N}\end{array}$} & $\begin{array}{l}\text { Median conc. } \\
\text { n } \\
\text { Min conc. } \\
\text { Max conc. }\end{array}$ & $\begin{array}{c}2.9 \\
30 \\
1.9 \\
3.3\end{array}$ & $\begin{array}{c}3.6 \\
29 \\
.86 \\
5.7\end{array}$ & $\begin{array}{c}8.4 \\
29 \\
3.9 \\
11\end{array}$ & $\begin{array}{c}4.7 \\
29 \\
1.3 \\
8.4\end{array}$ & $\begin{array}{c}7.0 \\
30 \\
1.7 \\
11\end{array}$ \\
\hline & $\begin{array}{l}\text { Min load } \\
\text { Max load }\end{array}$ & $20^{.81}$ & $52^{.81}$ & $\begin{array}{l}4.6 \\
124\end{array}$ & $204^{3.1}$ & $\begin{array}{l}8.3 \\
891\end{array}$ \\
\hline $\begin{array}{l}\text { Nitrite + } \\
\text { nitrate, } \\
\text { dissolved } \\
\text { as } \mathrm{N}\end{array}$ & $\begin{array}{l}\text { Median conc. } \\
\text { n } \\
\text { Min conc. } \\
\text { Max conc. } \\
\text { Min load } \\
\text { Max load }\end{array}$ & $\begin{array}{c}2.7 \\
30 \\
1.9 \\
3.3 \\
.81 \\
20\end{array}$ & $\begin{array}{c}3.6 \\
29 \\
.80 \\
5.7 \\
.78 \\
52\end{array}$ & $\begin{array}{c}8.1 \\
29 \\
3.9 \\
11 \\
4.6 \\
124\end{array}$ & $\begin{array}{c}4.7 \\
29 \\
1.2 \\
8.4 \\
3.1 \\
204\end{array}$ & $\begin{array}{c}7.0 \\
30 \\
1.7 \\
11 \\
8.3 \\
891\end{array}$ \\
\hline $\begin{array}{l}\text { Ammonia, } \\
\text { total as N }\end{array}$ & $\begin{array}{l}\text { Median conc. } \\
\text { n } \\
\text { Min conc. } \\
\text { Max conc. } \\
\text { Min load } \\
\text { Max load }\end{array}$ & $\begin{array}{l}30 \\
30 \\
<.01 \\
.10 \\
<.01 \\
.59\end{array}$ & $\begin{array}{c}29 \\
.12 \\
.04 \\
2.9 \\
.05 \\
1.4\end{array}$ & $\begin{array}{c}28 \\
.02 \\
.72 \\
.03 \\
3.1\end{array}$ & $\begin{array}{l}29 \\
.08 \\
.02 \\
.78 \\
.12 \\
9.7\end{array}$ & $\begin{array}{l}30.10 \\
.02 \\
2.1 \\
.33 \\
81\end{array}$ \\
\hline $\begin{array}{l}\text { Ammonia, } \\
\text { dissolved } \\
\text { as } \mathrm{N}\end{array}$ & $\begin{array}{l}\text { Median conc. } \\
\text { n } \\
\text { Min conc. } \\
\text { Max conc. } \\
\text { Min load } \\
\text { Max load }\end{array}$ & $\begin{array}{l}30 \\
30 \\
<.01 \\
.07 \\
<.01 \\
.42\end{array}$ & $\begin{array}{l}29 \\
.12 \\
.04 \\
2.2 \\
.05 \\
1.2\end{array}$ & $\begin{array}{c}28 \\
.10 \\
.02 \\
.72 \\
.03 \\
3.1\end{array}$ & $\begin{array}{l}29.08 \\
.02 \\
.78 \\
.09 \\
9.7\end{array}$ & $\begin{array}{l}30.10 \\
.02 \\
2.1 \\
.23 \\
81\end{array}$ \\
\hline $\begin{array}{l}\text { Ammonia + } \\
\text { organic } \\
\text { nitrogen, } \\
\text { total as N }\end{array}$ & $\begin{array}{l}\text { Median conc. } \\
\text { n } \\
\text { Min conc. } \\
\text { Max conc. } \\
\text { Min load } \\
\text { Max load }\end{array}$ & $\begin{array}{l}30 \\
.47 \\
<.20 \\
1.6 \\
.64 \\
3.4\end{array}$ & $\begin{array}{l}1.3 \\
28 \\
15 \\
25^{.50} \\
.65\end{array}$ & $\begin{array}{c}.89 \\
28 \\
.10 \\
2.5 \\
.14 \\
9.6\end{array}$ & $\begin{array}{l}1.2 \\
29 \\
.60 \\
10 \\
1.7 \\
36\end{array}$ & $\begin{array}{c}.99 \\
30 \\
.38 \\
4.4 \\
3.2 \\
169\end{array}$ \\
\hline $\begin{array}{l}\text { Ammonia + } \\
\text { organic } \\
\text { nitrogen, } \\
\text { dissolved } \\
\text { as } \mathrm{N}\end{array}$ & $\begin{array}{l}\text { Median conc. } \\
\text { n } \\
\text { Min conc. } \\
\text { Max conc. } \\
\text { Min load } \\
\text { Max load }\end{array}$ & $\begin{array}{l}.40 \\
30 \\
<.20 \\
.60 \\
<.06 \\
3.4\end{array}$ & ${ }_{13^{29}}^{.90}$ & $\begin{array}{l}\quad .82 \\
28 \\
<.20 \\
2.2 \\
.14 \\
8.7\end{array}$ & $\begin{array}{c}29.94 \\
.50 \\
8.8 \\
1.6 \\
36\end{array}$ & $\begin{array}{c}30.93 \\
.38 \\
3.7 \\
3.1 \\
142\end{array}$ \\
\hline $\begin{array}{l}\text { Nitrogen, } \\
\text { total as N }\end{array}$ & $\begin{array}{l}\text { Median conc. } \\
\text { n } \\
\text { Min conc. } \\
\text { Max conc. } \\
\text { Min load } \\
\text { Max load }\end{array}$ & $\begin{array}{c}3.4 \\
30 \\
2.1 \\
4.7 \\
22^{.91}\end{array}$ & $\begin{array}{c}5.1 \\
29 \\
2.4 \\
18 \\
1.9 \\
57\end{array}$ & $\begin{array}{c}9.6 \\
28 \\
4.7 \\
12 \\
6.5 \\
124\end{array}$ & $\begin{array}{c}6.2 \\
29 \\
2.5 \\
12 \\
6.8 \\
221\end{array}$ & $\begin{array}{c}8.0 \\
30 \\
4.7 \\
12 \\
22 \\
972\end{array}$ \\
\hline
\end{tabular}


Table 12.-Water-quality characteristics of base flow in the Small Watershed, April 1, 1984 through March 31, 1986 (pre-Best-Management Practice period data) -Continued

[Conc., concentration in milligrams per liter; load, load in pounds per day; $n$, number of values;

$\mathrm{N}$, nitrogen; $\mathrm{P}$, phosphorus; Min, minimum; Max, maximum; $\mathrm{ft}^{3} / \mathrm{s}$, cubic feet per second; <, less than;

-, sample not analyzed for indicated constituent]

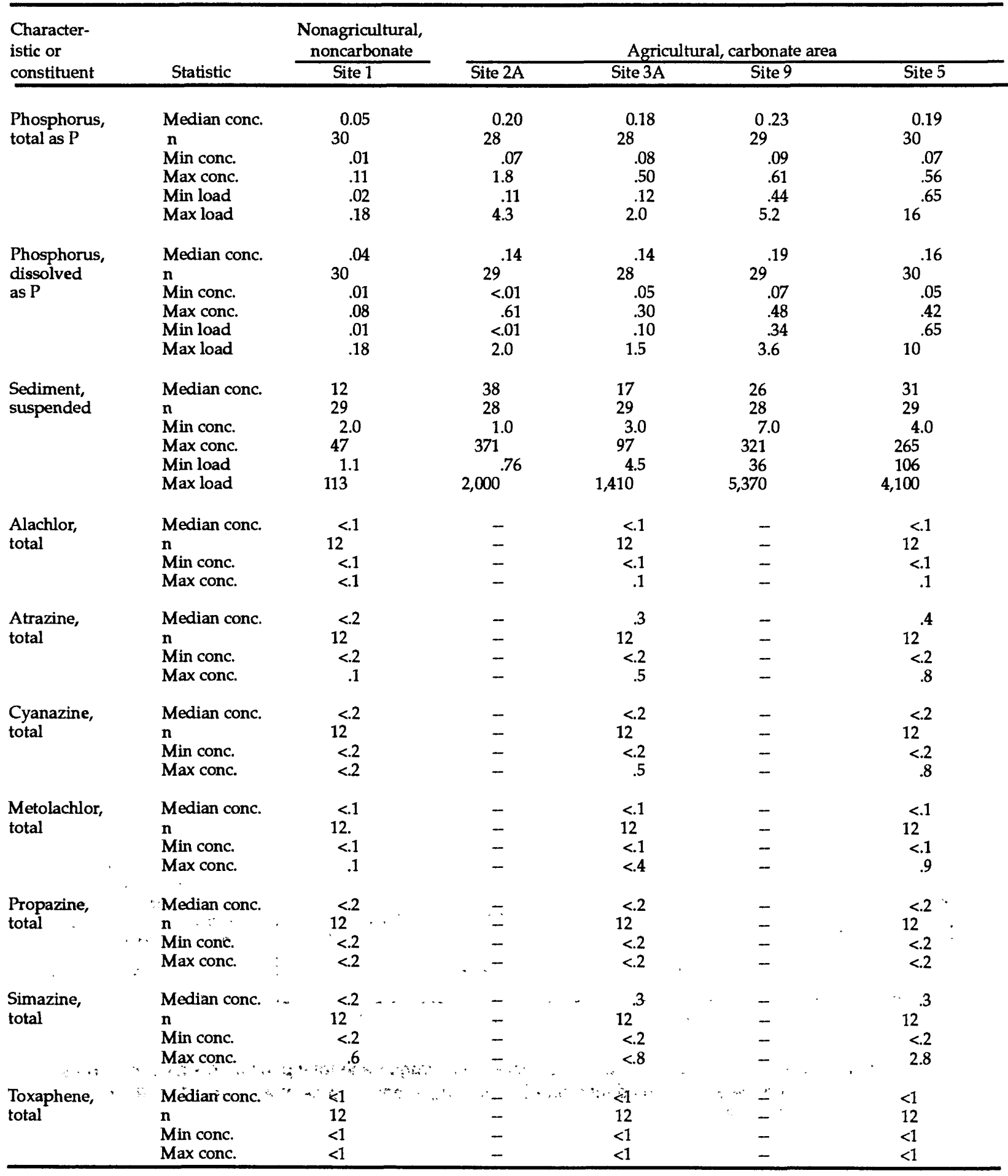




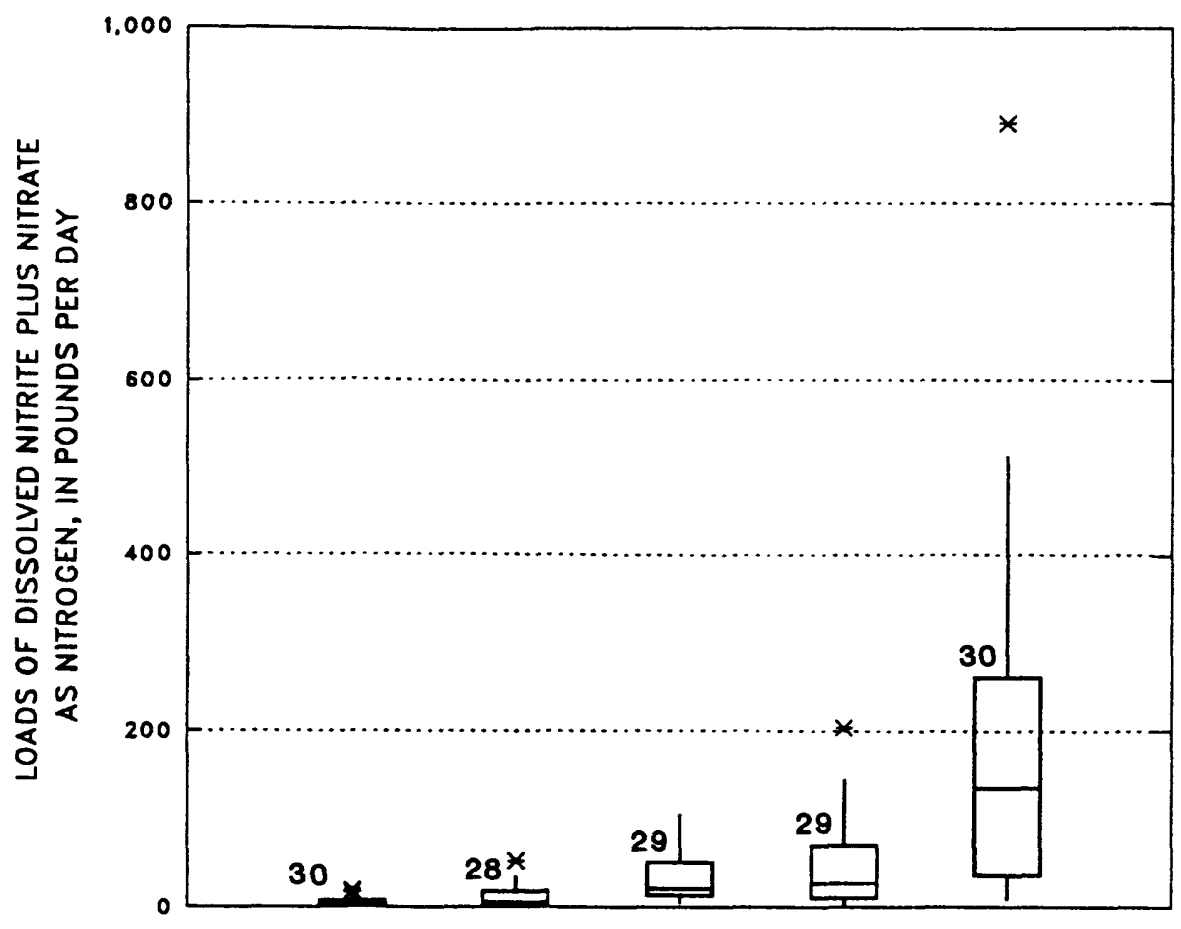

EXPLANATION

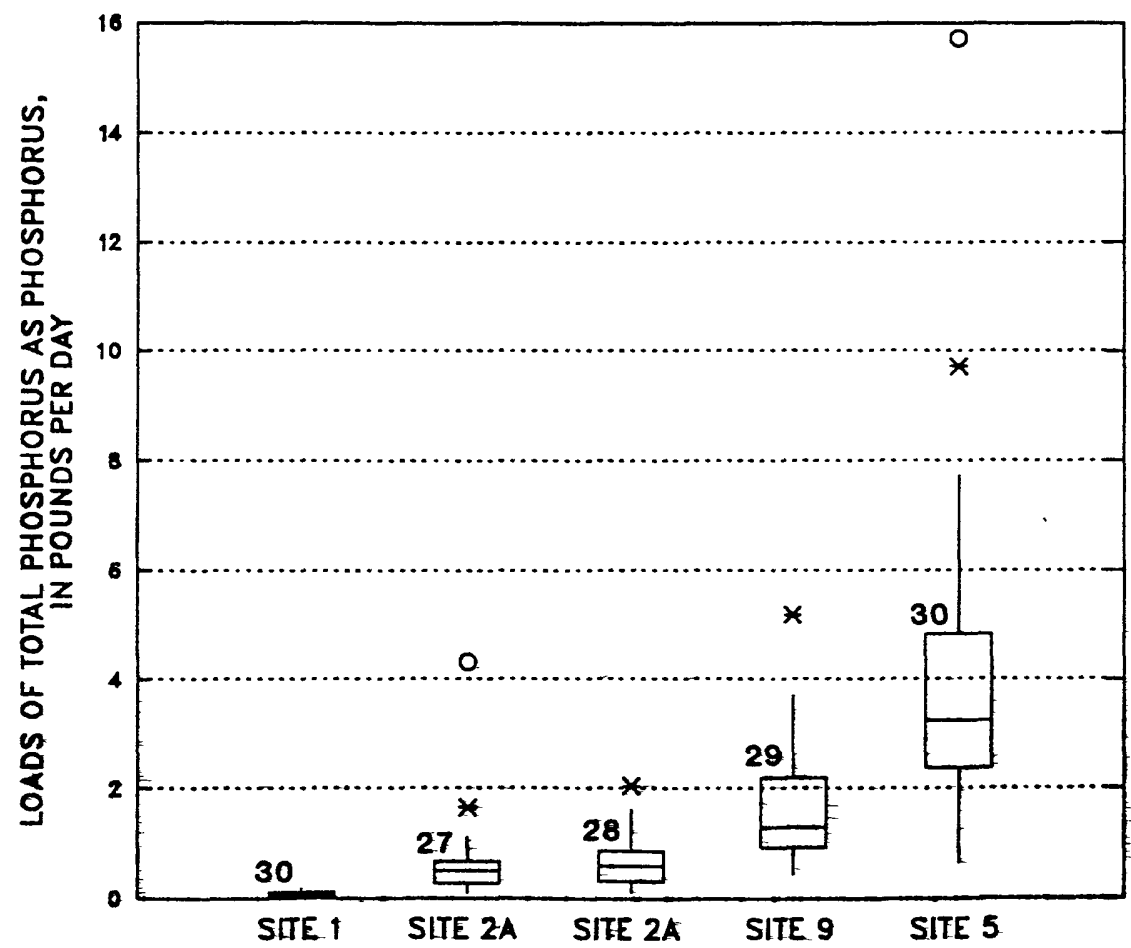

- Detached Value ${ }^{t}$

$\times$ outsloe value 2

$30^{4} \mid$ UPPER WHISKER 3

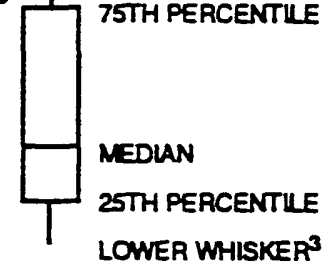

1 A value 23 times the interquarile range from the box.

$2 A$ value $>1.5$ and $s 3$ umes the interquarile range from the box.

3 Upper whisker is the largest dam point less than or equal to the upper quarile plus 15 imee the interquerile range. Lower whisker is the smallest dita point oreater then minus 1.5 tines the inerquarile range.

in = numbar of obsenations in analyeis.

Figure 10.-Loads of dissolved nitrite plus nitrate as nitrogen and tolaf phosphons as phosphorus at suface-water sites during pre-Best-Management Practice phase, April 1, 1984, through March 31, 1986. 

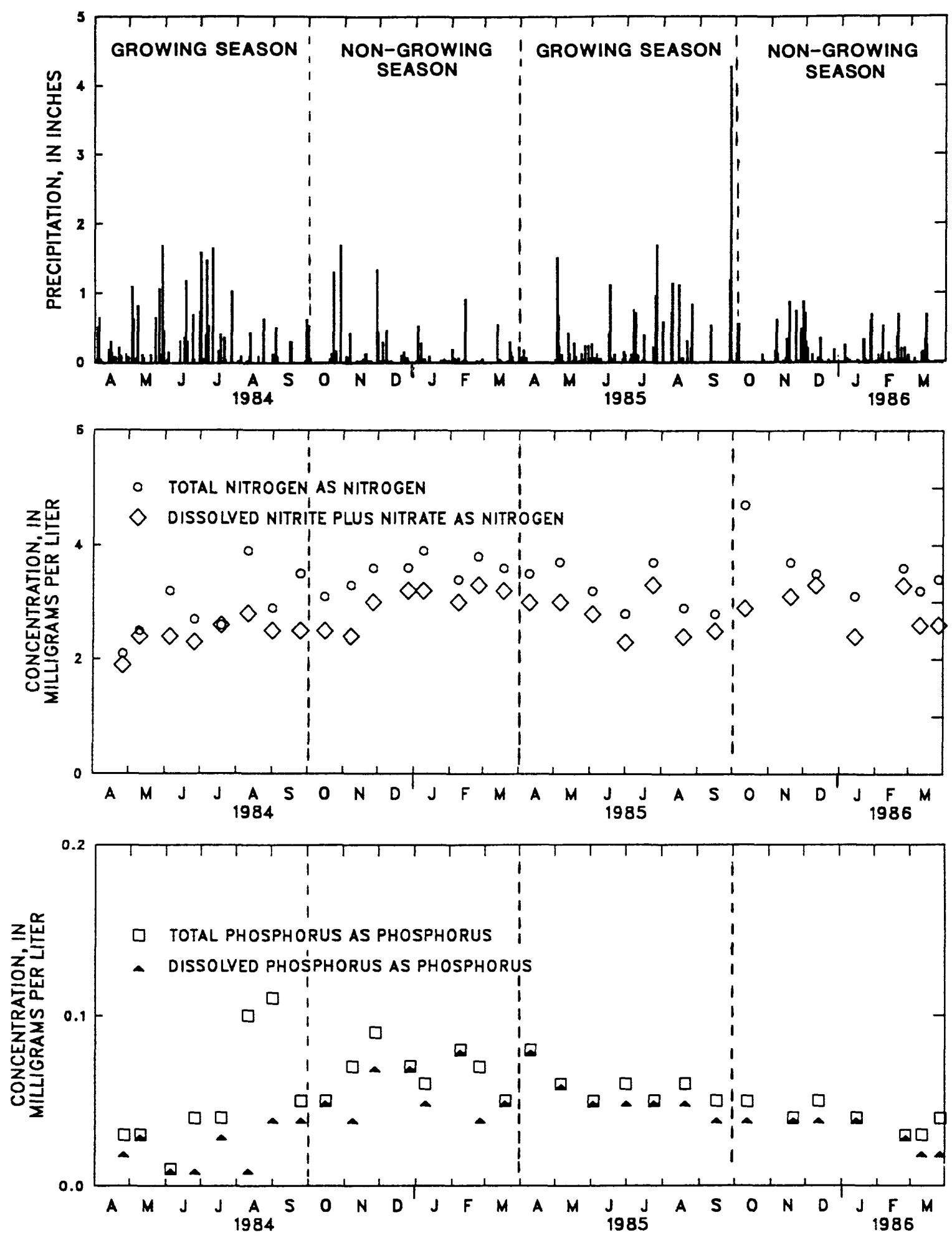

Figure 11.-Precipitation in the Small Watershed and concentrations of total nitrogen, and dissolved nitrite plus nitrate as nitrogen, and total and dissolved phosphorus as phosphorus in base flow at Site 1, April 1, 1984, through March 31, 1986. 

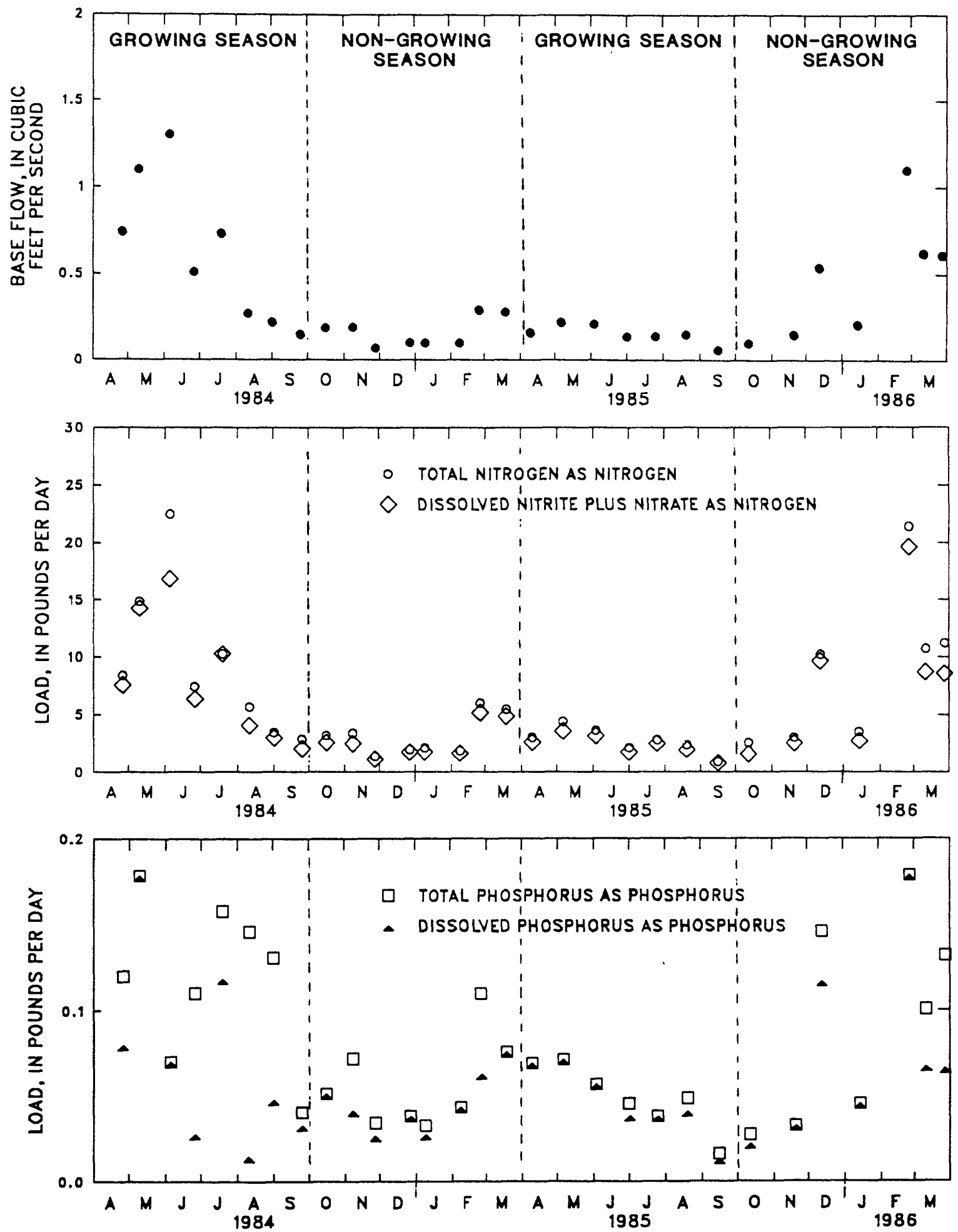

Figure 12.--Base flow and loads of total nitrogen, and dissolved nitrite plus nitrate as nitrogen, and total and dissolved phosphorus, as phosphorus at Site 1, April 1, 1984, through March 31, 1986. 

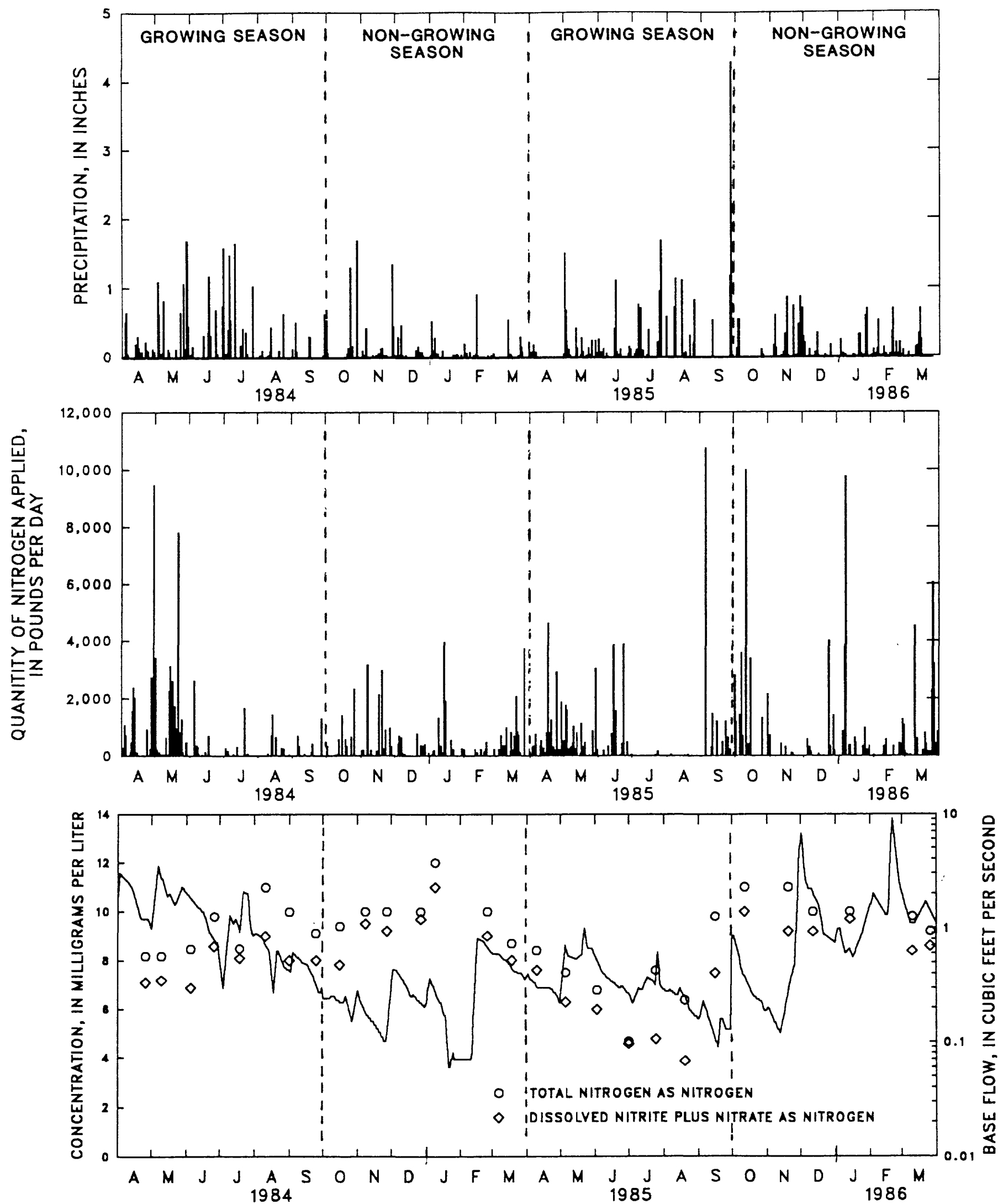

Figure 13.--Precipitation in the Small Watershed, nitrogen applications, and concentrations of total nitrogen, and dissolved nitrite plus nitrate as nitrogen in base flow at Site 3A, April 1, 1984, through March $31,1986$. 


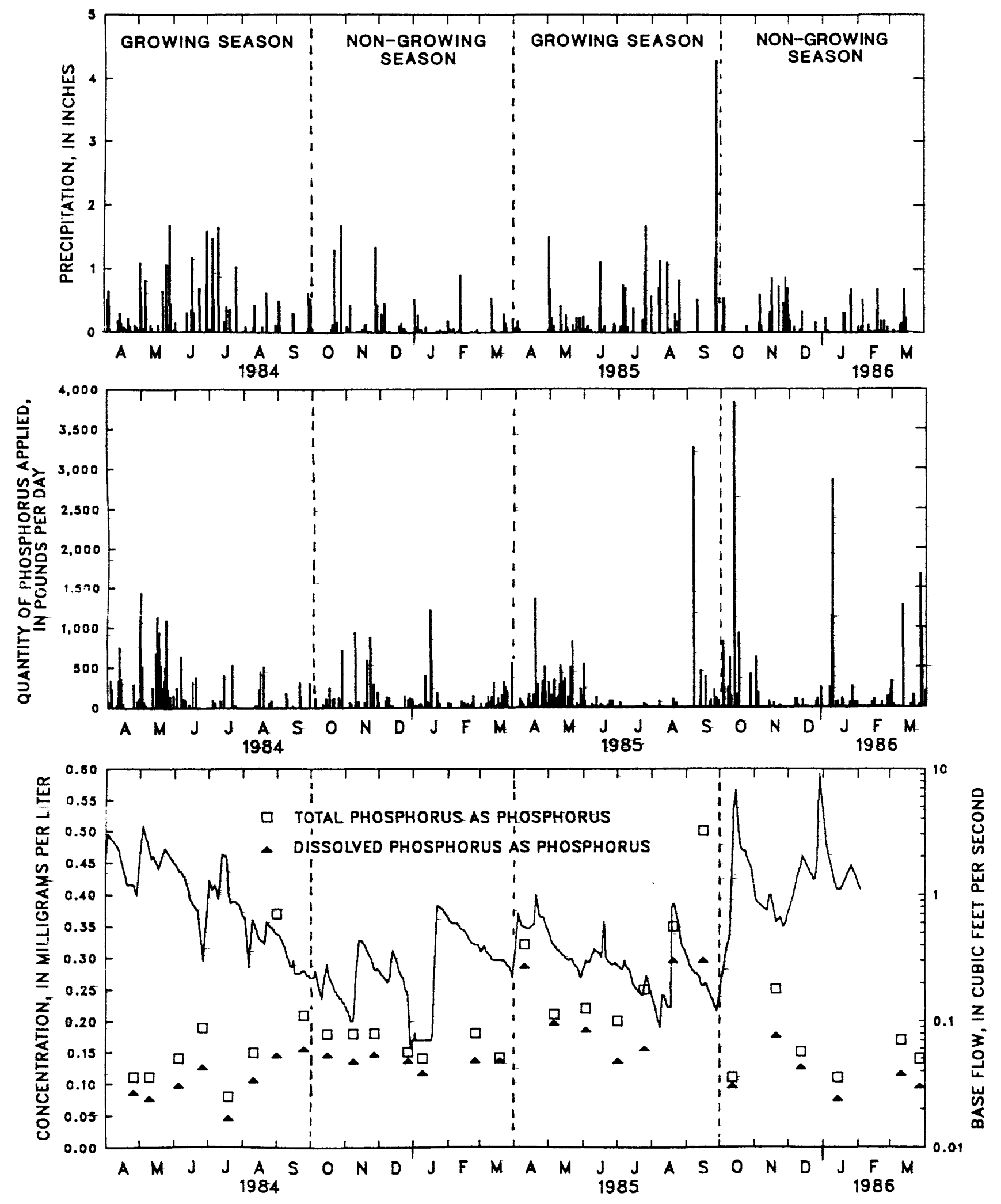

Figure 14.--Precipitation in the Small Watershed, phosphorus applications, and concentrations of total and dissolved phosphorus as phosphorus in base flow at Site 3A, April 1, 1984, through March 31, 1986. 

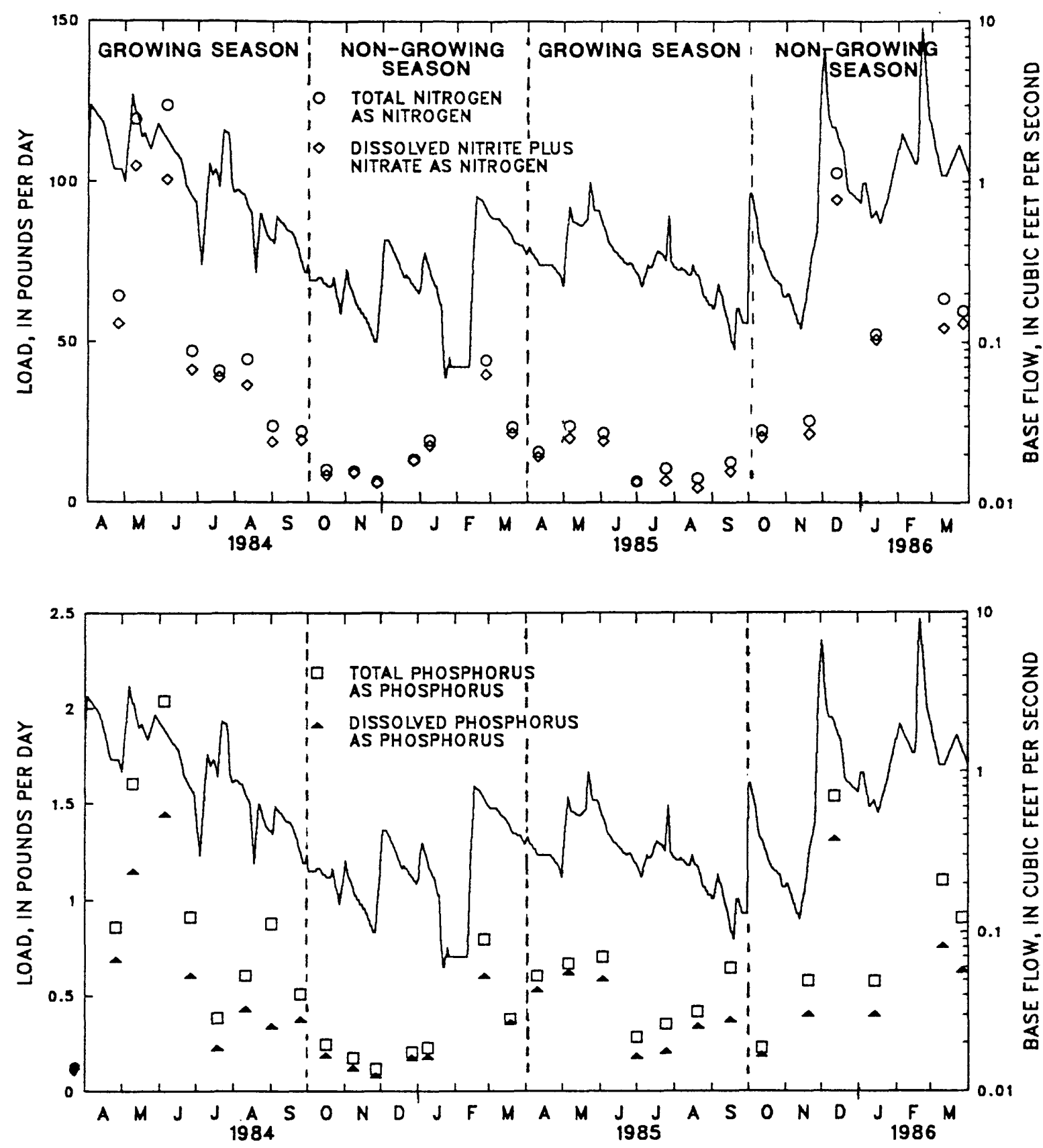

Figure 15.--Loads of total nitrogen and dissolved nitrite plus nitrate as nitrogen, and total and dissolved phosphorus as phosphorus in base flow at Site 3A, April 1, 1984, through March 31, 1986. 

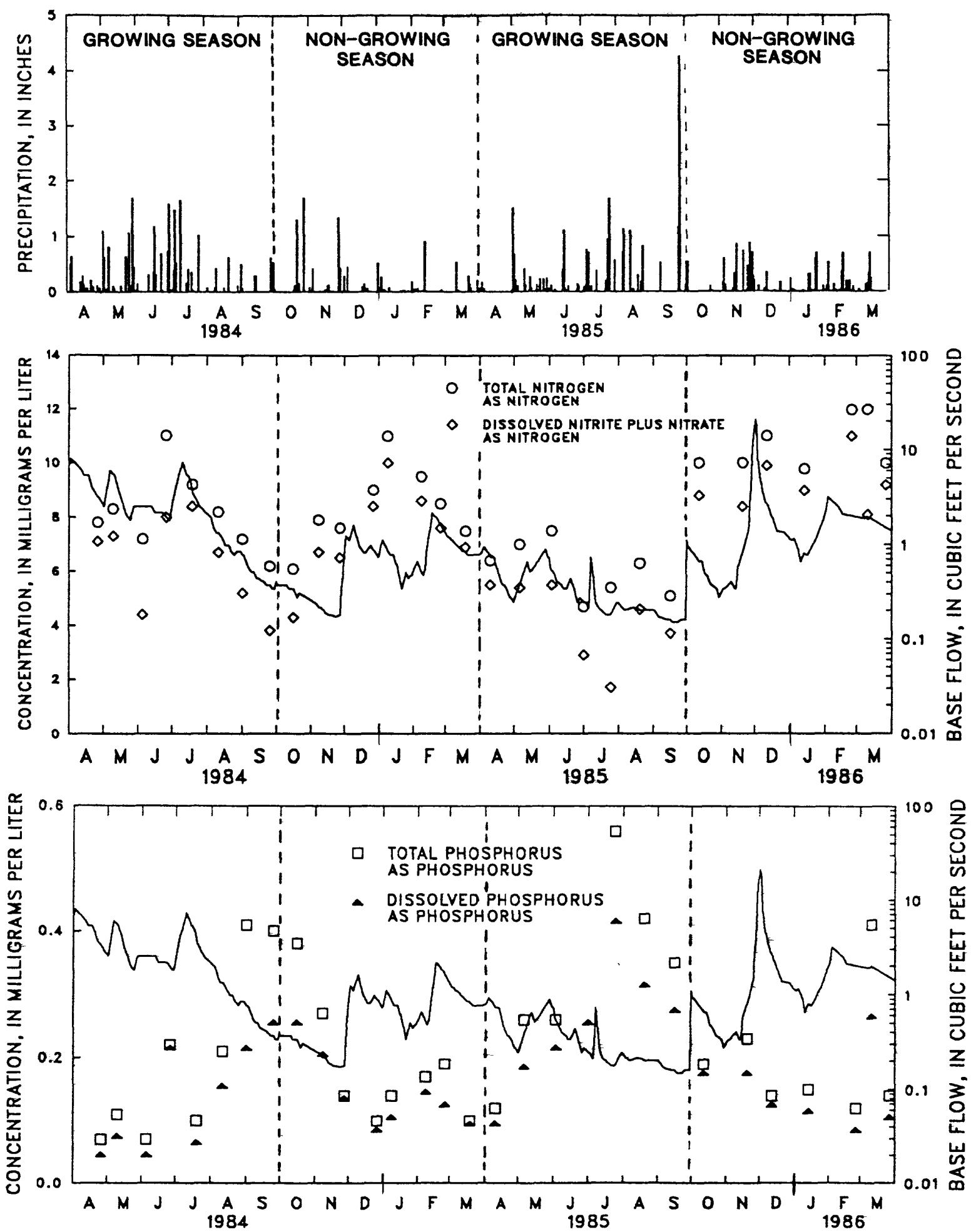

Figure 16.-Precipitation in the Small Watershed and concentrations of total nitrogen and dissolved nitrite plus nitrate as nitrogen, and total and dissolved phosphorus as phosphorus in base flow at Site 5 , April 1, 1984, through March 31, 1986. 

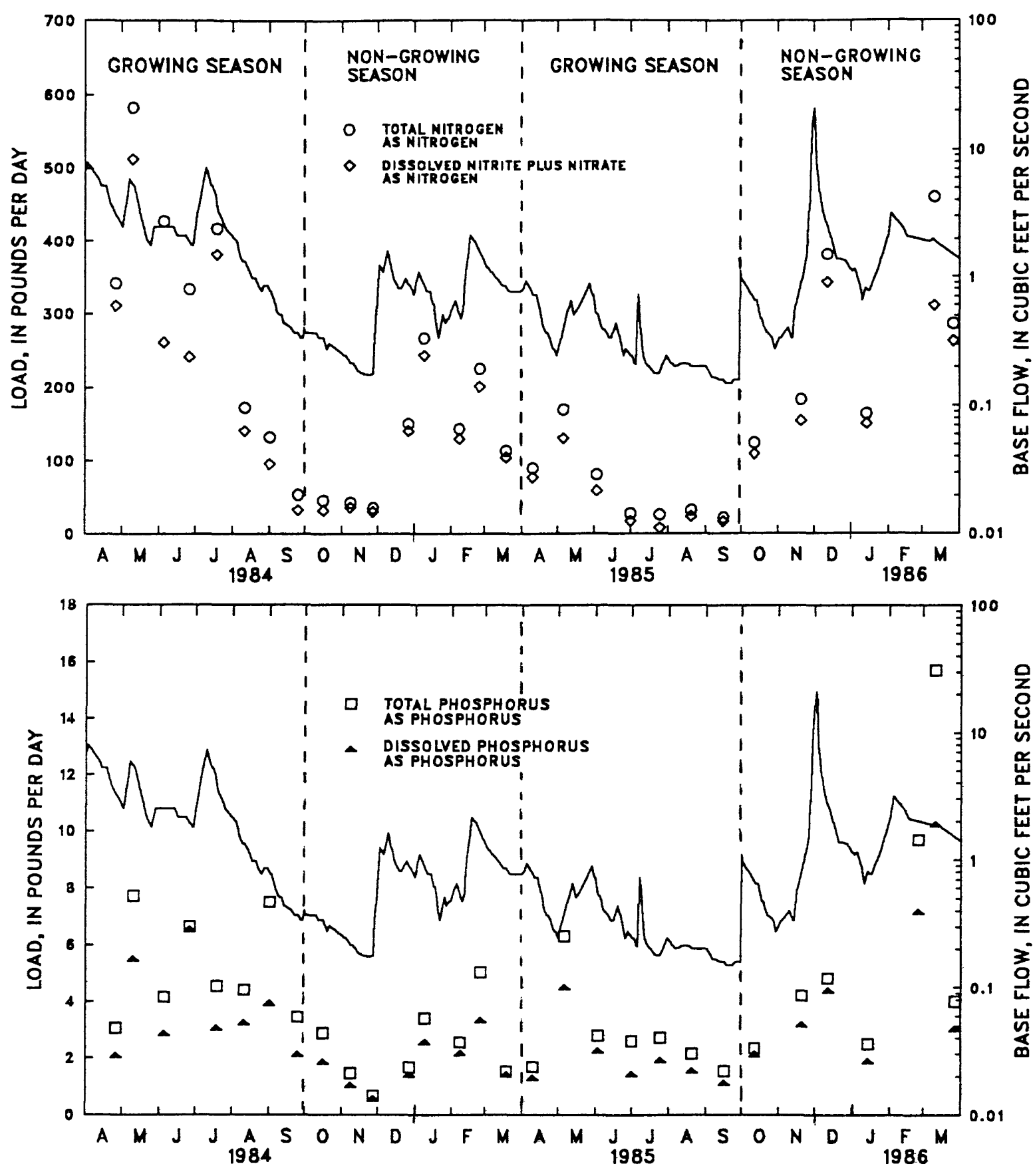

Figure 17.-Loads of total nitrogen and dissolved nitrite plus nitrate as nitrogen, and total and dissolved phosphorus as phosphorus in base flow at Site 5, April 1, 1984, through March 31, 1986. 

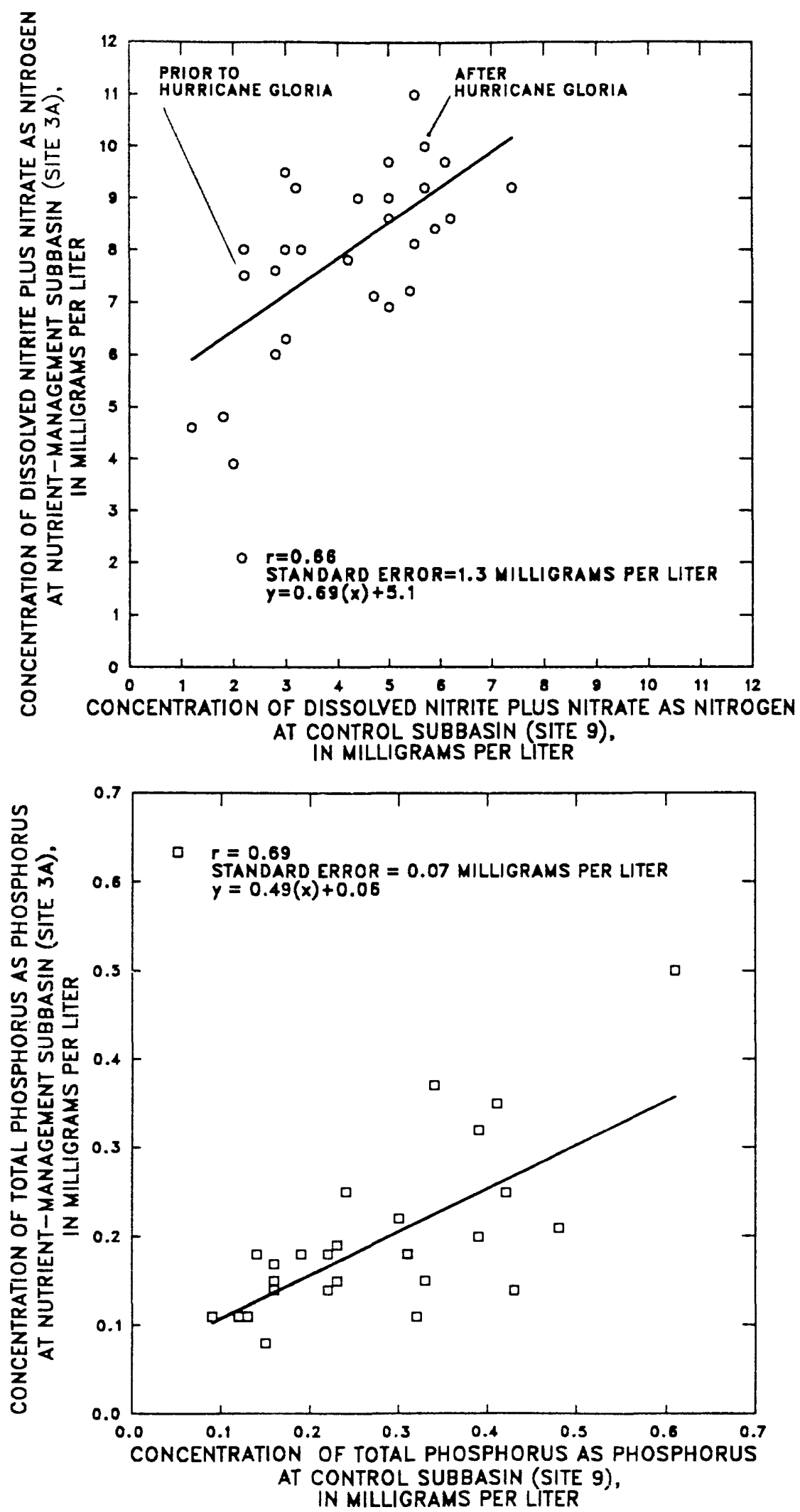

Figure 18.--Relation of concentrations of dissolved nitrite plus nitrate as nitrogen and total phosphorus as phosphorus between the Paired-Watersheds. 

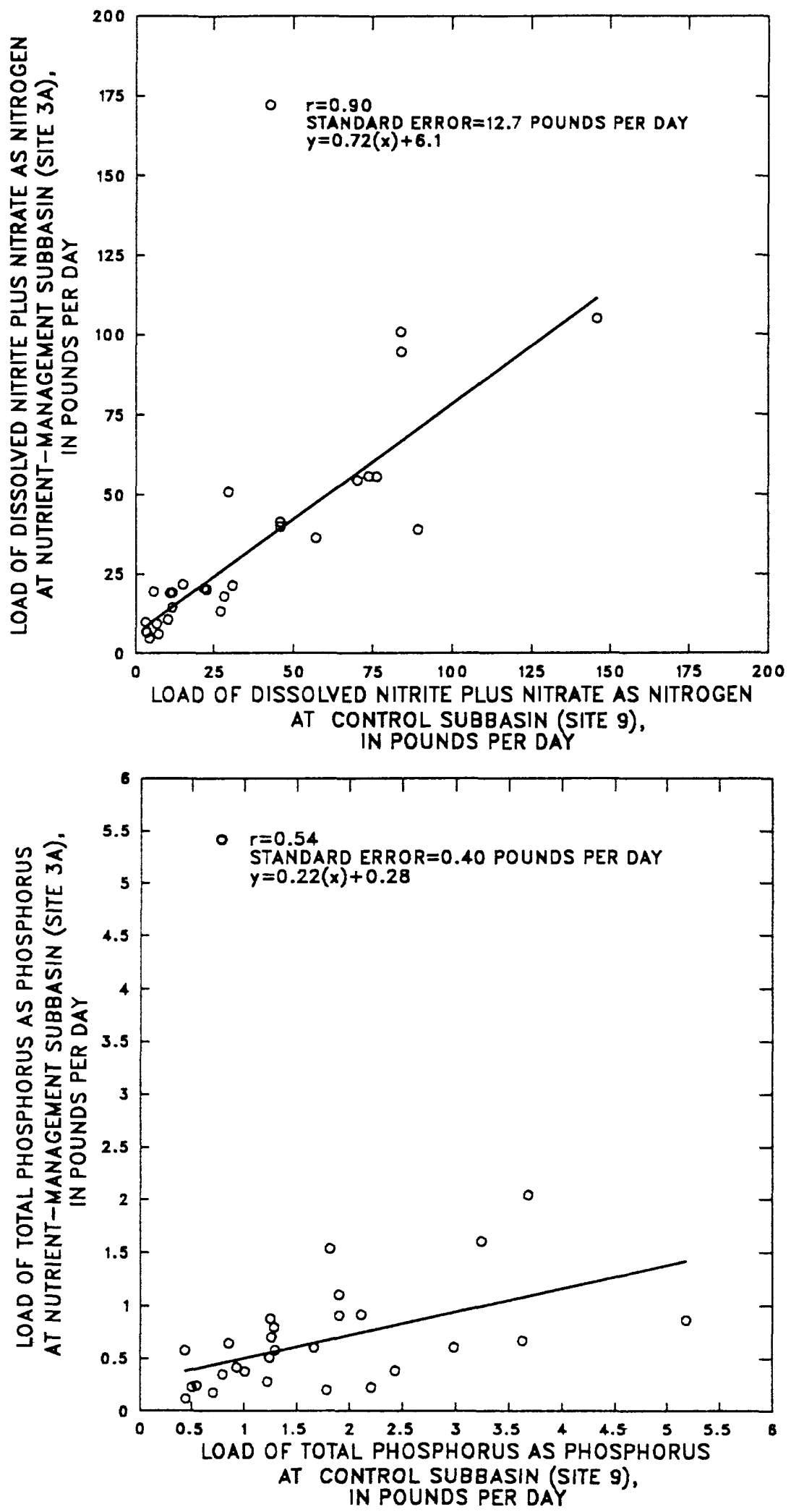

Figure 19.--Relation of loads of dissolved nitrite plus nitrate as nitrogen and total phosphorus as phosphorus between the Paired-Watersheds. 
Table 13a.-Monthly and annual nutrient and suspended-sediment loads in base flow at the Nutrient-Management Subbasin (Site 3A) during the pre-Best-Management Practice phase, April 1, 1984 through March 31, 1986

[Base flow, in inches of runoff; loads, in pounds]

\begin{tabular}{|c|c|c|c|c|c|c|c|c|}
\hline Month & Year & $\begin{array}{l}\text { Base } \\
\text { flow }\end{array}$ & $\begin{array}{c}\text { Total } \\
\text { nitrogen }\end{array}$ & $\begin{array}{c}\text { Total } \\
\text { nitrite } \\
\text { plus } \\
\text { nitrate } \\
\text { nitrogen }\end{array}$ & $\begin{array}{c}\text { Dissolved } \\
\text { nitrite } \\
\text { plus } \\
\text { nitrate } \\
\text { nitrogen }\end{array}$ & $\begin{array}{c}\text { Total } \\
\text { phosphorus }\end{array}$ & $\begin{array}{c}\text { Dissolved } \\
\text { phosphorus }\end{array}$ & $\begin{array}{r}\text { Suspended } \\
\text { sediment }\end{array}$ \\
\hline \multirow[t]{2}{*}{ April } & 1984 & 1.51 & 4,080 & 2,750 & 2,650 & 39 & 30 & 4,460 \\
\hline & 1985 & 27 & 450 & 400 & 400 & 15 & 14 & 3,070 \\
\hline \multirow[t]{2}{*}{ May } & 1984 & 1.72 & 3,380 & 3,110 & 2,860 & 49 & 35 & 19,100 \\
\hline & 1985 & .47 & 710 & 570 & 570 & 21 & 19 & 1,080 \\
\hline \multirow[t]{2}{*}{ June } & 1984 & 1.04 & 2,240 & 2,010 & 1,860 & 39 & 27 & 17,400 \\
\hline & 1985 & 30 & 370 & 280 & 280 & 13 & 10 & 820 \\
\hline \multirow[t]{2}{*}{ July } & 1984 & .92 & 1,790 & 1,650 & 1,640 & 22 & 14 & 3,300 \\
\hline & 1985 & .27 & 380 & 240 & 240 & 13 & 9 & 1,420 \\
\hline \multirow[t]{2}{*}{ Aug. } & 1984 & .50 & 1,050 & 890 & 850 & 20 & 11 & 7,150 \\
\hline & 1985 & 20 & 280 & 150 & 150 & 13 & 11 & 870 \\
\hline \multirow[t]{2}{*}{ Sept. } & 1984 & 34 & 680 & 560 & 550 & 20 & 11 & 3,160 \\
\hline & 1985 & .11 & 360 & 270 & 270 & 20 & 10 & 940 \\
\hline \multirow[t]{2}{*}{ Oct. } & 1984 & .18 & 420 & 380 & 360 & 8 & 7 & 650 \\
\hline & 1985 & 31 & 700 & 590 & 590 & 12 & 9 & 940 \\
\hline \multirow[t]{2}{*}{ Nov. } & 1984 & .13 & 270 & 250 & 250 & 5 & 4 & 260 \\
\hline & 1985 & .55 & 1,080 & 890 & 890 & 21 & 16 & 2,280 \\
\hline \multirow[t]{2}{*}{ Dec. } & 1984 & .24 & 570 & 540 & 530 & 9 & 8 & 780 \\
\hline & 1985 & 1.48 & 3,030 & 2,720 & 2,720 & 48 & 40 & 4,240 \\
\hline \multirow[t]{2}{*}{ Jan. } & 1985 & .15 & 360 & 330 & 320 & 4 & 4 & 210 \\
\hline & 1986 & .69 & 1,540 & 1,460 & 1,460 & 19 & 14 & 2,470 \\
\hline \multirow[t]{2}{*}{ Feb. } & 1985 & 29 & 740 & 670 & 670 & 13 & 10 & 490 \\
\hline & 1986 & 2.06 & 4,280 & 3,830 & 3,830 & 63 & 45 & 9,230 \\
\hline \multirow[t]{2}{*}{ March } & 1985 & .42 & 780 & 710 & 710 & 15 & 13 & 1,160 \\
\hline & 1986 & 1.11 & 2,440 & 2,170 & 2,170 & 39 & 28 & 5,000 \\
\hline \multirow[t]{2}{*}{ Total } & year 1 & 7.44 & 16,360 & 13,850 & 13,250 & 243 & 174 & 58,120 \\
\hline & year 2 & 7.82 & 15,620 & 13,570 & $\underline{13,570}$ & $\underline{293}$ & $\underline{225}$ & $\underline{32,360}$ \\
\hline \multicolumn{2}{|l|}{ Total } & 15.26 & 31,980 & 27,420 & $26,82 \theta$ & 536 & 399 & 90,480 \\
\hline
\end{tabular}


Table 13b.-Monthly and annual nutrient and suspended-sediment loads in base flow at the Small Watershed (Site 5) during the pre-Best-Management

Practice phase, April 1, 1984 through March 31, 1986

Base flow, in inches of runoff; loads, in pounds]

\begin{tabular}{|c|c|c|c|c|c|c|c|c|}
\hline Month & Year & $\begin{array}{l}\text { Base } \\
\text { flow }\end{array}$ & $\begin{array}{c}\text { Total } \\
\text { nitrogen }\end{array}$ & $\begin{array}{c}\text { Total } \\
\text { nitrite } \\
\text { plus } \\
\text { nitrate } \\
\text { nitrogen }\end{array}$ & $\begin{array}{l}\text { Dissolved } \\
\text { nitrite } \\
\text { plus } \\
\text { nitrate } \\
\text { nitrogen }\end{array}$ & $\begin{array}{c}\text { Total } \\
\text { phosphorus }\end{array}$ & $\begin{array}{l}\text { Dissolved } \\
\text { phosphorus }\end{array}$ & $\begin{array}{l}\text { Suspended } \\
\text { sediment }\end{array}$ \\
\hline April & $\begin{array}{l}1984 \\
1985\end{array}$ & $\begin{array}{r}2.08 \\
.39\end{array}$ & $\begin{array}{r}16,800 \\
2,140\end{array}$ & $\begin{array}{r}15,600 \\
1,800\end{array}$ & $\begin{array}{r}15,500 \\
1,800\end{array}$ & $\begin{array}{r}150 \\
47\end{array}$ & $\begin{array}{r}120 \\
38\end{array}$ & $\begin{array}{r}13,300 \\
5,320\end{array}$ \\
\hline May & $\begin{array}{l}1984 \\
1985\end{array}$ & $\begin{array}{r}1.53 \\
.42\end{array}$ & $\begin{array}{r}12,400 \\
3,310\end{array}$ & $\begin{array}{r}11,200 \\
2,340\end{array}$ & $\begin{array}{l}9,950 \\
2,340\end{array}$ & $\begin{array}{l}150 \\
120\end{array}$ & $\begin{array}{r}110 \\
92\end{array}$ & $\begin{array}{l}58,400 \\
30,600\end{array}$ \\
\hline June & $\begin{array}{l}1984 \\
1985\end{array}$ & $\begin{array}{r}1.12 \\
.29\end{array}$ & $\begin{array}{l}9,380 \\
1,610\end{array}$ & $\begin{array}{r}8,590 \\
970\end{array}$ & $\begin{array}{r}6,610 \\
970\end{array}$ & $\begin{array}{r}150 \\
84\end{array}$ & $\begin{array}{r}130 \\
60\end{array}$ & $\begin{array}{l}48,400 \\
25,300\end{array}$ \\
\hline July & $\begin{array}{l}1984 \\
1985\end{array}$ & $\begin{array}{r}1.76 \\
.23\end{array}$ & $\begin{array}{r}15,100 \\
1,250\end{array}$ & $\begin{array}{r}13,900 \\
440\end{array}$ & $\begin{array}{r}12,800 \\
440\end{array}$ & $\begin{array}{l}220 \\
120\end{array}$ & $\begin{array}{r}190 \\
87\end{array}$ & $\begin{array}{l}24,500 \\
18,100\end{array}$ \\
\hline Aug. & $\begin{array}{l}1984 \\
1985\end{array}$ & $\begin{array}{l}.71 \\
.19\end{array}$ & $\begin{array}{l}4,790 \\
1,000\end{array}$ & $\begin{array}{r}3,860 \\
600\end{array}$ & $\begin{array}{r}3,810 \\
600\end{array}$ & $\begin{array}{r}150 \\
75\end{array}$ & $\begin{array}{l}97 \\
57\end{array}$ & $\begin{array}{r}33,100 \\
7,180\end{array}$ \\
\hline Sept. & $\begin{array}{l}1984 \\
1985\end{array}$ & $\begin{array}{l}.34 \\
.16\end{array}$ & $\begin{array}{l}1,930 \\
1,020\end{array}$ & $\begin{array}{r}1,330 \\
780\end{array}$ & $\begin{array}{r}1,230 \\
760\end{array}$ & $\begin{array}{r}120 \\
53\end{array}$ & $\begin{array}{l}69 \\
43\end{array}$ & $\begin{array}{r}19,800 \\
4,110\end{array}$ \\
\hline Oct. & $\begin{array}{l}1984 \\
1985\end{array}$ & $\begin{array}{l}.27 \\
.40\end{array}$ & $\begin{array}{l}1,700 \\
3,700\end{array}$ & $\begin{array}{l}1,210 \\
3,280\end{array}$ & $\begin{array}{l}1,190 \\
3,080\end{array}$ & $\begin{array}{l}95 \\
83\end{array}$ & $\begin{array}{l}66 \\
74\end{array}$ & $\begin{array}{r}14,500 \\
5,390\end{array}$ \\
\hline Nov. & $\begin{array}{l}1984 \\
1985\end{array}$ & $\begin{array}{l}.20 \\
.86\end{array}$ & $\begin{array}{l}1,300 \\
6,620\end{array}$ & $\begin{array}{l}1,120 \\
5,650\end{array}$ & $\begin{array}{l}1,100 \\
5,600\end{array}$ & $\begin{array}{r}36 \\
130\end{array}$ & $\begin{array}{r}30 \\
110\end{array}$ & $\begin{array}{r}23,000 \\
6,480\end{array}$ \\
\hline Dec. & $\begin{array}{l}1984 \\
1985\end{array}$ & $\begin{array}{r}.64 \\
1.47\end{array}$ & $\begin{array}{r}4,630 \\
13,300\end{array}$ & $\begin{array}{r}4,270 \\
11,600\end{array}$ & $\begin{array}{r}4,190 \\
11,540\end{array}$ & $\begin{array}{r}64 \\
190\end{array}$ & $\begin{array}{r}61 \\
170\end{array}$ & $\begin{array}{l}64,400 \\
10,700\end{array}$ \\
\hline Jan. & $\begin{array}{l}1985 \\
1986\end{array}$ & $\begin{array}{l}.46 \\
.66\end{array}$ & $\begin{array}{l}4,110 \\
6,180\end{array}$ & $\begin{array}{l}4,190 \\
5,700\end{array}$ & $\begin{array}{l}3,730 \\
5,700\end{array}$ & $\begin{array}{l}55 \\
87\end{array}$ & $\begin{array}{l}46 \\
69\end{array}$ & $\begin{array}{r}3,370 \\
10,900\end{array}$ \\
\hline Feb. & $\begin{array}{l}1985 \\
1986\end{array}$ & $\begin{array}{r}.63 \\
1.08\end{array}$ & $\begin{array}{r}5,340 \\
21,200\end{array}$ & $\begin{array}{r}3,730 \\
19,400\end{array}$ & $\begin{array}{r}4,810 \\
19,400\end{array}$ & $\begin{array}{l}110 \\
230\end{array}$ & $\begin{array}{r}82 \\
180\end{array}$ & $\begin{array}{r}9,840 \\
49,300\end{array}$ \\
\hline March & $\begin{array}{l}1985 \\
1986\end{array}$ & $\begin{array}{l}.59 \\
.95\end{array}$ & $\begin{array}{r}3,850 \\
18,900\end{array}$ & $\begin{array}{r}3,480 \\
11,400\end{array}$ & $\begin{array}{r}3,480 \\
11,400\end{array}$ & $\begin{array}{r}64 \\
350\end{array}$ & $\begin{array}{r}54 \\
240\end{array}$ & $\begin{array}{l}11,500 \\
78,400\end{array}$ \\
\hline Total & $\begin{array}{l}\text { year } 1 \\
\text { year } 2\end{array}$ & $\begin{array}{r}10.33 \\
7.10 \\
\end{array}$ & $\begin{array}{l}81,780 \\
80,200 \\
\end{array}$ & $\begin{array}{l}73,100 \\
63,960 \\
\end{array}$ & $\begin{array}{l}68,400 \\
63,630 \\
\end{array}$ & $\begin{array}{l}1,364 \\
1,569 \\
\end{array}$ & $\begin{array}{l}1,055 \\
1,220 \\
\end{array}$ & $\begin{array}{l}324,110 \\
251,780 \\
\end{array}$ \\
\hline Total & & 17.43 & 161,980 & 137,060 & 132,030 & 2,933 & 2,275 & 575,890 \\
\hline
\end{tabular}


Table 14.-Concentrations of total atrazine and total simazine in base flow at Site 1 prior to and following the identification of the disposal area, May 10, 1984 through November 20, 1985

[Detection limits for atrazine and simazine were 0.10 and $0.20 \mu \mathrm{g} / \mathrm{L}$ (micrograms per liter), respectively, except as noted. Concentrations below these limits were considered undetected; <, less than]

\begin{tabular}{ccr}
\hline Date & $\begin{array}{c}\text { Atrazine } \\
(\mu \mathrm{g} / \mathrm{L})\end{array}$ & $\begin{array}{c}\text { Simazine } \\
(\mu \mathrm{gg} / / \mathrm{L})\end{array}$ \\
\hline $05 / 10 / 84$ & $<0.10$ & 0.20 \\
$06 / 05 / 84$ & .10 & $<.20$ \\
$06 / 26 / 84$ & $<.10$ & 20 \\
$07 / 19 / 84$ & $<.10$ & $<.20$ \\
$08 / 11 / 84$ & $<.10$ & $<.20$ \\
$09 / 01 / 84$ & $<.10$ & $<.20$ \\
$09 / 25 / 84$ & $<.10$ & $<.20$ \\
$10 / 16 / 84$ & $<.10$ & .60 \\
$05 / 06 / 85$ & Disposal area identified 1 & $<20$ \\
$07 / 25 / 85$ & $<.20$ & $<20$ \\
$08 / 20 / 85$ & $<.20$ & $<20$ \\
$11 / 20 / 85$ & $<.20$ & $<.20$ \\
\hline
\end{tabular}

${ }^{1}$ The detection limit used by the Pennsylvania Department of Environmental Resources laboratory for these samples was increased from 0.10 to $0.20 \mathrm{mg} / \mathrm{L}$. 


\section{Stormflow}

Stormflow, for the purpose of this report, represents the total streamflow minus the base flow from the time of the initial rise in stream stage until the stream stabilizes or returns to the prestorm level. Thus, total streamflow during storms consists of both surface runoff and base flow from ground water. Storms were defined as beginning when the stream stage increased $0.10 \mathrm{ft}$ at Site $3 \mathrm{~A}$ and $0.25 \mathrm{ft}$ at Site 5 , and ending when the rate of decrease was less than $0.05 \mathrm{ft}$ per hour at the sites. Tables 15 and 16 summarize streamflow for selected storms. During the pre-BMP phase there were 33 storms at Site $3 \mathrm{~A}$ and 45 storms at Site 5. Samples from 29 of the storms at Site $3 \mathrm{~A}$, representing 94 percent of the annual stormflow, were analyzed for nutrients and/or sediment. Samples from 34 of the storms at Site 5, representing 96 percent of the annual stormflow at that site, were analyzed for nutrients and/or sediment.

Maximum and minimum instantaneous nutrient, suspended-sediment, and pesticide concentrations in stormflow at the Nutrient- Management Subbasin (Site 3A) and the Small Watershed (Site 5) are given in table 15. Most maximum nutrient concentrations during storms at the downstream site (Site 5) were only slightly lower than those at the upstream site (Site $3 \mathrm{~A}$ ). This indicates that tributaries draining areas with minor agricultural land use did not greatly dilute the nutrient content of the stream between these sites during storms and that the concentrations of nitrogen and phosphorus discharged to the stream downstream from Site 3A (Nutrient-Management Subbasin) are about equal to those at Site 3A. Maximum concentrations of total nitrogen at Sites $3 \mathrm{~A}$ and 5 were measured during storms in May shortly after crops were planted. The maximum total-nitrogen concentration at Site $3 \mathrm{~A}$ was $34 \mathrm{mg} / \mathrm{L}$ on May 26, 1984, and the maximum concentration at Site 5 was $28 \mathrm{mg} / \mathrm{L}$ on May 21, 1985. Maximum concentrations of total phosphorus ( $20 \mathrm{mg} / \mathrm{L}$ and $17 \mathrm{mg} / \mathrm{L}$ at Sites $3 \mathrm{~A}$ and 5, respectively) were measured during a storm on May 21,1985 . The maximum suspended-sediment concentration at Site $3 \mathrm{~A}(16,700 \mathrm{mg} / \mathrm{L})$ was measured during a storm on May 26, 1984, and the maximum concentration at $\operatorname{Site} 5(34,300 \mathrm{mg} / \mathrm{L})$ was measured on May 21, 1985. Pesticide concentrations in stormflow were determined during the growing season each year of the study. Results were similar for both sites. Maximum concentrations of metolachlor, atrazine, alachlor, and cyanazine were measured in May after pesticides had been applied to the crops.

Concentrations decreased through the growing season. Maximum simazine concentrations were measured in July.

At the onset of storms, nitrite plus nitrate-nitrogen concentrations in the stream decreased rapidly and concentrations of total ammonia plus organic nitrogen, total phosphorus, and suspended sediment increased rapidly at Sites $3 \mathrm{~A}$ and 5 (figs. 20 and 21). Storms with short durations and little runoff from overland flow usually had little effect on nitrite plus nitrate-nitrogen concentrations during and following the storms. However, if the storms were intense and produced $1.0 \mathrm{in}$. or more of precipitation, such as Hurricane Gloria, then more of the runoff came from surface flow than from subsurface flow. It was during these large storms that dissolved-nitrite plus nitrate concentrations were initially diluted from overland flow until the streamflows peaked. Afterwards, dissolved-nitrite plus nitrate concentrations began to increase as less of the stormflow consisted of overland flow and more consisted of subsurface flow and ground water that migrated through the nutrient-rich soils.

About $13,000 \mathrm{lb}$ of nitrogen discharged during storms from Site $3 \mathrm{~A}$ and $69,000 \mathrm{lb}$ from Site 5 during the pre-BMP phase. Half of the nitrogen discharged during storms from both sites was organic nitrogen (table 16). During the first year of the study, 5,800 tons of suspended sediment were discharged from Site 5 during storms, resulting in a storm yield of about 1.6 tons/acre (tons per acre) (table 16). Storm yields for particular fields are probably significantly greater because of differences in land use. More than 19 percent of the suspended sediment discharged from Site 5 during the pre-BMP phase was transported on May 21, 1985 , when $2.8 \mathrm{in}$. of rain fell in the basin. 
Table 15.-Ranges of instantaneous storm concentrations from April 1, 1984 through March 31, 1986

[Concentration, in milligrams per liter except where noted; $n$, number of values; $\mu g / L$, micrograms per liter; $<$, less than]

\begin{tabular}{|c|c|c|c|}
\hline Constituent & Statistic & $\begin{array}{c}\text { Nutrient-Management } \\
\text { Subbasin (Site 3A) }\end{array}$ & $\begin{array}{c}\text { Small Watershed } \\
\text { (Site 5) }\end{array}$ \\
\hline $\begin{array}{l}\text { Nitrite }+ \\
\text { nitrate, } \\
\text { total as } N\end{array}$ & $\begin{array}{l}\mathbf{n} \\
\text { Minimum } \\
\text { Maximum }\end{array}$ & ${ }_{15}^{178} .90$ & $13^{237} .94$ \\
\hline $\begin{array}{l}\text { Nitrite }+ \\
\text { nitrate, } \\
\text { dissolved as } \mathrm{N}\end{array}$ & $\begin{array}{l}\mathrm{n} \\
\text { Minimum } \\
\text { Maximum }\end{array}$ & ${ }_{11}^{61} .78$ & ${ }_{11}^{90} .92$ \\
\hline $\begin{array}{l}\text { Ammonia, } \\
\text { total as } \mathrm{N}\end{array}$ & $\begin{array}{l}\mathbf{n} \\
\text { Minimum } \\
\text { Maximum }\end{array}$ & $\begin{array}{l}158 \\
.02 \\
6.6\end{array}$ & $\begin{array}{c}217 \\
.02 \\
6.0\end{array}$ \\
\hline $\begin{array}{l}\text { Ammonia, } \\
\text { dissolved } \\
\text { as } \mathrm{N}\end{array}$ & $\begin{array}{l}\mathbf{n} \\
\text { Minimum } \\
\text { Maximum }\end{array}$ & $\begin{array}{l}61 \\
.02 \\
5.9\end{array}$ & $\begin{array}{l}91 \\
6.02\end{array}$ \\
\hline $\begin{array}{l}\text { Ammonia + organic } \\
\text { nitrogen, } \\
\text { total as } \mathrm{N}\end{array}$ & $\begin{array}{l}\mathbf{n} \\
\text { Minimum } \\
\text { Maximum }\end{array}$ & $28^{180}$ & $2^{232}$ \\
\hline $\begin{array}{l}\text { Ammonia + organic } \\
\text { nitrogen, dissolved } \\
\text { as } \mathrm{N}\end{array}$ & $\begin{array}{l}\mathbf{n} \\
\text { Minimum } \\
\text { Maximum }\end{array}$ & ${ }_{15}^{61} .26$ & $\frac{88}{2.22}$ \\
\hline $\begin{array}{l}\text { Nitrogen, } \\
\text { total as N }\end{array}$ & $\begin{array}{l}\mathrm{n} \\
\text { Minimum } \\
\text { Maximum }\end{array}$ & $\begin{array}{l}176 \\
2.8 \\
34\end{array}$ & $\begin{array}{c}232 \\
3.2 \\
28\end{array}$ \\
\hline $\begin{array}{l}\text { Phosphorus, } \\
\text { total as P }\end{array}$ & $\begin{array}{l}\mathbf{n} \\
\text { Minimum } \\
\text { Maximum }\end{array}$ & ${ }_{20}^{179} .10$ & ${ }_{17}^{234} .07$ \\
\hline $\begin{array}{l}\text { Phosphorus, } \\
\text { dissolved } \\
\text { as } \mathrm{P}\end{array}$ & $\begin{array}{l}\mathrm{n} \\
\text { Minimum } \\
\text { Maximum }\end{array}$ & $\begin{array}{c}61 \\
3.07\end{array}$ & $\begin{array}{l}90 \\
.05 \\
2.6\end{array}$ \\
\hline $\begin{array}{l}\text { Sediment, } \\
\text { suspended }\end{array}$ & $\begin{array}{l}\text { n } \\
\text { Minimum } \\
\text { Maximum }\end{array}$ & $\begin{array}{r}175 \\
6.0 \\
16,700\end{array}$ & $\begin{array}{c}253 \\
4.0 \\
34,300\end{array}$ \\
\hline $\begin{array}{l}\text { Alachlor, } \\
\text { total, in } \\
\mu \mathrm{g} / \mathrm{L}\end{array}$ & $\begin{array}{l}\mathbf{n} \\
\text { Minimum } \\
\text { Maximum }\end{array}$ & $\begin{array}{l}16 \\
<1 \\
56\end{array}$ & $\begin{array}{l}24 \\
<.5 \\
85\end{array}$ \\
\hline $\begin{array}{l}\text { Atrazine, } \\
\text { total, in } \\
\mu \mathrm{g} / \mathrm{L}\end{array}$ & $\begin{array}{l}\text { n } \\
\text { Minimum } \\
\text { Maximum }\end{array}$ & $\begin{array}{c}16 \\
<.1 \\
210\end{array}$ & $\begin{array}{r}24 \\
<1 \\
120\end{array}$ \\
\hline $\begin{array}{l}\text { Cyanazine, } \\
\text { total, in } \\
\mu \mathrm{g} / \mathrm{L}\end{array}$ & $\begin{array}{l}\mathbf{n} \\
\text { Minimum } \\
\text { Maximum }\end{array}$ & $\begin{array}{c}16 \\
<.2 \\
200\end{array}$ & $\begin{array}{l}24 \\
<.8 \\
72\end{array}$ \\
\hline $\begin{array}{l}\text { Metolachlor, } \\
\text { total, in } \\
\mu \mathrm{g} / \mathrm{L}\end{array}$ & $\begin{array}{l}\mathbf{n} \\
\text { Minimum } \\
\text { Maximum }\end{array}$ & $\begin{array}{c}16 \\
250\end{array}$ & $\begin{array}{l}24 \\
<.1 \\
75\end{array}$ \\
\hline $\begin{array}{l}\text { Propazine, } \\
\text { total, in } \\
\mu \mathrm{g} / \mathrm{L}\end{array}$ & $\begin{array}{l}\mathbf{n} \\
\text { Minimum } \\
\text { Maximum }\end{array}$ & $\begin{array}{c}16 \\
16.2 \\
1<4\end{array}$ & $\begin{array}{l}24 \\
13\end{array}$ \\
\hline $\begin{array}{l}\text { Simazine, } \\
\text { total, in } \\
\mu \mathrm{g} / \mathrm{L}\end{array}$ & $\begin{array}{l}\text { n } \\
\text { Minimum } \\
\text { Maximum }\end{array}$ & $\begin{array}{l}16 \\
<.2 \\
14\end{array}$ & $\begin{array}{l}24 \\
21\end{array}$ \\
\hline $\begin{array}{l}\text { Toxaphene, } \\
\text { total, in } \\
\mu \mathrm{g} / \mathrm{L}\end{array}$ & $\begin{array}{l}\mathbf{n} \\
\text { Minimum } \\
\text { Maximum }\end{array}$ & $\begin{array}{l}16 \\
<1 \\
20\end{array}$ & $\begin{array}{r}24 \\
<1 \\
1<10\end{array}$ \\
\hline
\end{tabular}

${ }^{1}$ Detection limits for these samples were higher because of the volume of the sample collected. 

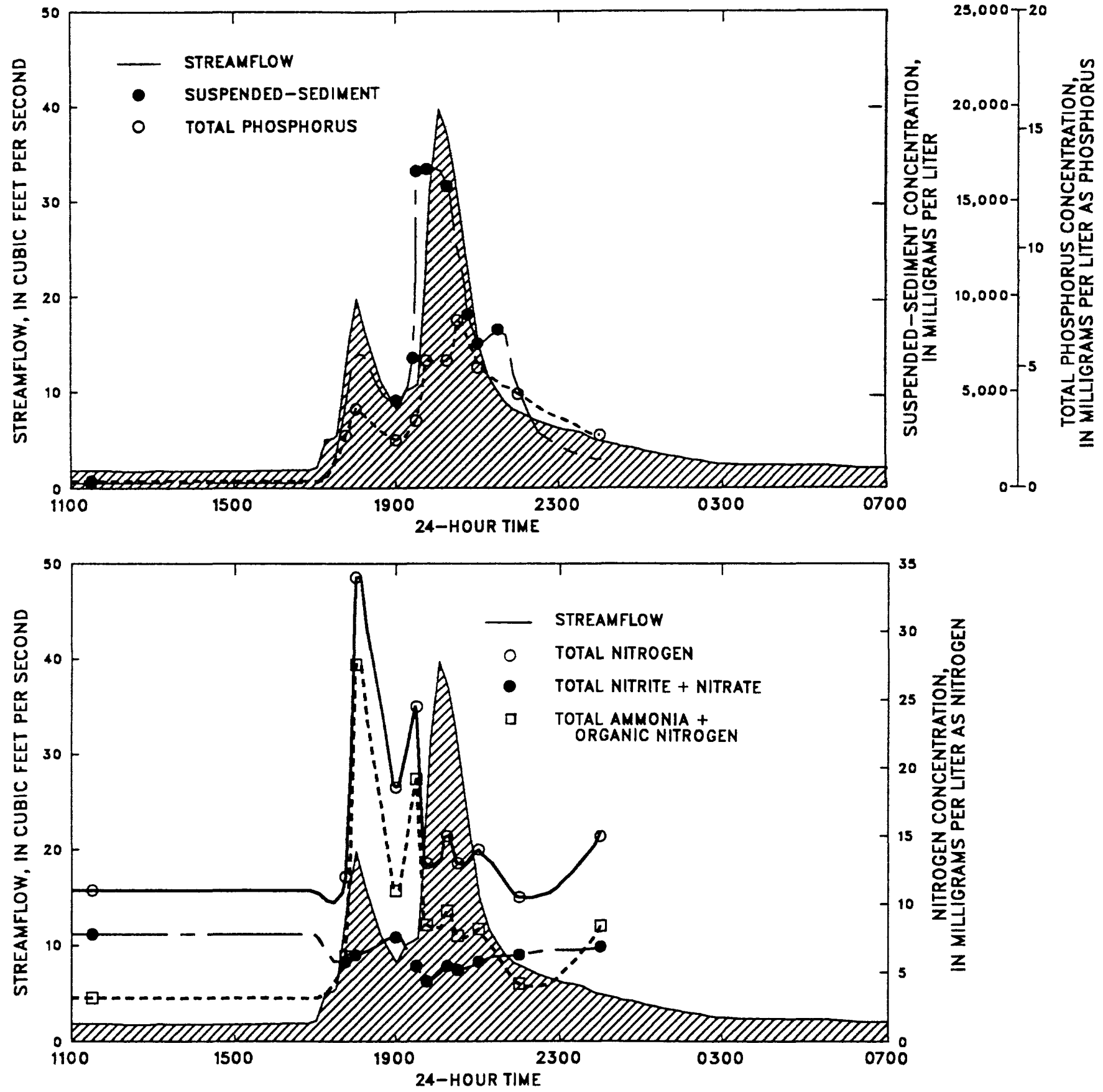

Figure 20.--Streamflow and concentrations of suspended sediment, total-nitrogen constituents, and total phosphorus at the Nutrient-Management Subbasin during the storm of May 26-27, 1984. 
Table 16.-Nitrogen, phosphorus, and suspended-sediment loads during storm days at the Nutrient-Management Subbasin (Site 3A) and the Small Watershed (Site 5), April 4, 1984 through March 15, 1986

[Streamflow in cubic feet per second; sediment loads in tons, nutrient loads in pounds; -, no data]

\begin{tabular}{|c|c|c|c|c|c|c|c|c|c|c|c|}
\hline Date & $\begin{array}{c}\text { Mean } \\
\text { stream } \\
\text { flow }\end{array}$ & $\begin{array}{l}\text { Total } \\
\text { nitrite } \\
\text { plus } \\
\text { nitrate } \\
\text { nitrogen }\end{array}$ & $\begin{array}{c}\text { Dissolved } \\
\text { nitrite } \\
\text { plus } \\
\text { nitrate } \\
\text { nitrogen }\end{array}$ & $\begin{array}{c}\text { Total } \\
\text { ammonia } \\
\text { nitrogen }\end{array}$ & $\begin{array}{c}\text { Dissolved } \\
\text { ammonia } \\
\text { nitrogen }\end{array}$ & $\begin{array}{c}\text { Total } \\
\text { ammonia } \\
\text { plus } \\
\text { organic } \\
\text { nitrogen }\end{array}$ & $\begin{array}{c}\text { Dissolved } \\
\text { ammonia } \\
\text { plus } \\
\text { organic } \\
\text { nitrogen }\end{array}$ & $\begin{array}{c}\text { Total } \\
\text { nitrogen }\end{array}$ & $\begin{array}{l}\text { Total } \\
\text { phos- } \\
\text { phorus }\end{array}$ & $\begin{array}{c}\text { Dissolved } \\
\text { phos- } \\
\text { phorus }\end{array}$ & $\begin{array}{l}\text { Suspended } \\
\text { sediment }\end{array}$ \\
\hline
\end{tabular}

\begin{tabular}{|c|c|c|c|c|c|c|c|c|c|c|c|}
\hline $05 / 03 / 84$ & 3.0 & 82 & 80 & 63 & 63 & 180 & 104 & 262 & 26 & 8.5 & 7.9 \\
\hline $05 / 04 / 84$ & 13.0 & 206 & 191 & 179 & 175 & 301 & 224 & 507 & 93 & 24 & 59 \\
\hline $05 / 08 / 84$ & 5.7 & 158 & - & 17 & - & 107 & & 265 & 22 & - & \\
\hline $05 / 26 / 84$ & 5.7 & 178 & 158 & 79 & 60 & 220 & 163 & 407 & 92 & 14 & 5.7 \\
\hline $05 / 29 / 84$ & 12 & 324 & 294 & 102 & 80 & 394 & 172 & 718 & 114 & 31 & 57 \\
\hline $05 / 30 / 84$ & 9.1 & 310 & 289 & 55 & 47 & 141 & - & 451 & 26 & 14 & 5.2 \\
\hline $06 / 17 / 84$ & 2.2 & 74 & - & 6.9 & - & 39 & - & 113 & 18 & - & 5.6 \\
\hline $06 / 18 / 84$ & 4.3 & 78 & - & 13 & - & 90 & - & 168 & 30 & - & 6.7 \\
\hline $06 / 19 / 84$ & 2.2 & - & - & - & - & - & - & - & - & - & 2.5 \\
\hline $06 / 24 / 84$ & 2.2 & - & - & - & - & - & - & - & - & - & 2.0 \\
\hline $06 / 30 / 84$ & 1.6 & 42 & - & 3.9 & - & 27 & - & 69 & 3.8 & - & 1.5 \\
\hline $07 / 01 / 84$ & 25 & 629 & - & 69 & - & 865 & - & 1,494 & 454 & - & 153 \\
\hline $07 / 06 / 84$ & 2.3 & 36 & - & 6.5 & $=$ & 46 & - & 82 & 41 & - & 23 \\
\hline $\begin{array}{l}07 / 07 / 84 \\
07 / 10 / 84\end{array}$ & $\begin{array}{l}34 \\
1.3\end{array}$ & $\begin{array}{r}422 \\
84\end{array}$ & $\begin{array}{r}408 \\
84\end{array}$ & $\begin{array}{c}48 \\
1.5\end{array}$ & $\begin{array}{l}46 \\
1.5\end{array}$ & $\begin{array}{c}288 \\
6.7\end{array}$ & $\begin{array}{l}58 \\
3.0\end{array}$ & $\begin{array}{r}710 \\
91\end{array}$ & 272 & ${ }^{70}{ }_{8}$ & - \\
\hline $07 / 11 / 84$ & 11 & 203 & 189 & 82 & 82 & $\infty$ & 56 & 30 & 77 & 27 & 44 \\
\hline $07 / 27 / 84$ & 3.4 & 100 & - & 10 & - & 66 & - & 166 & 11 & - & 3.1 \\
\hline $10 / 28 / 84$ & 1.4 & 18 & - & 9.6 & - & 86 & - & 104 & 26 & - & 8.1 \\
\hline $10 / 29 / 84$ & 2.1 & 49 & - & 24 & - & 44 & - & 93 & 16 & - & - \\
\hline $11 / 29 / 84$ & 4.7 & 154 & - & 9.9 & - & 110 & - & 264 & 31 & - & - \\
\hline $02 / 12 / 85$ & 30 & 247 & 230 & 271 & 213 & 1,011 & 559 & 1,258 & 288 & 164 & 46 \\
\hline $02 / 13 / 85$ & 4.0 & 112 & 112 & 13 & 13 & 45 & 45 & 157 & 18 & 18 & 1.1 \\
\hline $05 / 03 / 85$ & 3.4 & 146 & 144 & 7.4 & 6.7 & 46 & 37 & 192 & 17 & 7.5 & - \\
\hline $05 / 20 / 85$ & .6 & 17 & - & 5.7 & - & 22 & - & 39 & 5.2 & - & - \\
\hline $05 / 21 / 85$ & 2.3 & 58 & - & - & - & 133 & - & 191 & 68 & - & 26 \\
\hline $06 / 16 / 85$ & 2.0 & 44 & - & $=$ & - & 82 & - & 126 & 21 & - & 4.1 \\
\hline $07 / 25 / 85$ & .7 & 17 & - & 5.7 & - & 22 & $=$ & 39 & 5.2 & - & - \\
\hline $07 / 27 / 85$ & 1.3 & 28 & 26 & 6.3 & 6.3 & 28 & 27 & 56 & 11 & 9.5 & - \\
\hline $08 / 07 / 85$ & 2.0 & 15 & - & 19 & - & 189 & - & 204 & 28 & - & - \\
\hline $08 / 08 / 85$ & 2.1 & 26 & - & 14 & - & 76 & - & 102 & 11 & - & - \\
\hline $08 / 14 / 85$ & 2.4 & $\overline{-}$ & - & - & - & - & - & - & - & - & - \\
\hline $09 / 26 / 85$ & 2 & 7.1 & 7.1 & .04 & .04 & 1.3 & .9 & 8.4 & 2 & .2 & 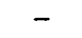 \\
\hline $09 / 27 / 85$ & $41^{2}$ & 660 & 650 & 114 & 114 & 860 & 545 & 1,520 & $553^{2}$ & 213 & - \\
\hline $09 / 28 / 85$ & 2.0 & 107 & 104 & 7.1 & 7.1 & 33 & 29 & 140 & 6.6 & 3.8 & - \\
\hline $11 / 04 / 85$ & 2 & 11 & - & .1 & - & 1 & - & 12 & 2 & - & - \\
\hline $11 / 05 / 85$ & 1.7 & 51 & - & 8.8 & - & 62 & - & 113 & 22 & - & .77 \\
\hline $11 / 16 / 85$ & 1.5 & - & - & - & - & - & - & - & - & - & - \\
\hline $11 / 17 / 85$ & 2.5 & - & - & - & - & - & - & - & - & - & - \\
\hline $11 / 22 / 85$ & 2.8 & 82 & - & 18 & - & 74 & - & 156 & 30 & - & - \\
\hline $11 / 23 / 85$ & .8 & 36 & - & 1.3 & - & 7.4 & - & 43 & 1.9 & - & - \\
\hline $11 / 26 / 85$ & 1.3 & - & - & - & - & - & - & - & - & - & .53 \\
\hline $11 / 27 / 85$ & 15 & - & - & - & - & $\ldots$ & - & - & - & - & 3.3 \\
\hline $11 / 28 / 85$ & 6.6 & - & - & - & - & - & - & - & - & - & 3.7 \\
\hline $11 / 29 / 85$ & 4.7 & - & - & - & - & & - & - & $\bar{m}$ & - & 1.3 \\
\hline $11 / 30 / 85$ & 10 & 260 & - & 24 & - & 370 & - & 630 & 192 & - & 17 \\
\hline $02 / 18 / 86$ & 7.1 & 124 & & 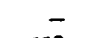 & - & 263 & - & 387 & 50 & - & 5.8 \\
\hline $02 / 19 / 86$ & 11 & 231 & 225 & 112 & 104 & 329 & 172 & 560 & 95 & 58 & 11 \\
\hline $02 / 20 / 86$ & 9.1 & 290 & 280 & 45 & 45 & 183 & 107 & 473 & 37 & 37 & 5.4 \\
\hline $02 / 21 / 86$ & 9.5 & & & - & - & & - & & & - & 11 \\
\hline $03 / 14 / 86$ & 4.5 & 147 & 147 & 24 & 17 & 125 & 56 & 272 & 37 & 23 & 13 \\
\hline $03 / 15 / 86$ & 5.9 & $\underline{204}$ & $\underline{204}$ & $\underline{20}$ & $\underline{19}$ & $\underline{124}$ & $\underline{67}$ & $\underline{328}$ & $\underline{31}$ & 17 & $\underline{7}$ \\
\hline Total & & 6,067 & 3,822 & 1,400 & 1,020 & 7,205 & 2,425 & 13,272 & 2,885 & 734 & 559 \\
\hline
\end{tabular}


Table 16.-Nitrogen, phosphorus, and suspended-sediment loads during storm days at the Nutrient-Management Subbasin (Site 3A) and the Small Watershed (Site 5), April 4, 1984 through March 15, 1986-Continued

[Streamflow in cubic feet per second; sediment loads in tons, nutrient loads in pounds; -, no data]

\begin{tabular}{|c|c|c|c|c|c|c|c|c|c|c|c|}
\hline Date & $\begin{array}{l}\text { Mean } \\
\text { stream } \\
\text { flow }\end{array}$ & $\begin{array}{c}\text { Total } \\
\text { nitrite } \\
\text { plus } \\
\text { nitrate } \\
\text { nitrogen }\end{array}$ & $\begin{array}{l}\text { Dissolved } \\
\text { nitrite } \\
\text { plus } \\
\text { nitrate } \\
\text { nitrogen }\end{array}$ & $\begin{array}{c}\text { Total } \\
\text { ammonia } \\
\text { nitrogen }\end{array}$ & $\begin{array}{l}\text { Dissolved } \\
\text { ammonia } \\
\text { nitrogen }\end{array}$ & $\begin{array}{c}\text { Total } \\
\text { ammonia } \\
\text { plus } \\
\text { organic } \\
\text { nitrogen }\end{array}$ & $\begin{array}{l}\text { Dissolved } \\
\text { ammonia } \\
\text { plus } \\
\text { organic } \\
\text { nitrogen }\end{array}$ & $\begin{array}{c}\text { Total } \\
\text { nitrogen }\end{array}$ & $\begin{array}{l}\text { Total } \\
\text { phos- } \\
\text { phorus }\end{array}$ & $\begin{array}{l}\text { Dissolved } \\
\text { phos- } \\
\text { phorus }\end{array}$ & $\begin{array}{c}\text { Suspended } \\
\text { sediment }\end{array}$ \\
\hline & & \multicolumn{10}{|c|}{ Site 5, Small Watershed } \\
\hline $\begin{array}{l}04 / 04 / 84 \\
04 / 05 / 84 \\
05 / 03 / 84 \\
05 / 04 / 84 \\
05 / 26 / 84\end{array}$ & $\begin{array}{l}20 \\
71 \\
7.5 \\
71 \\
23\end{array}$ & $\begin{array}{r}684 \\
1,777 \\
270 \\
1,386 \\
599\end{array}$ & $\begin{array}{r}667 \\
1,722 \\
264 \\
1,230 \\
560\end{array}$ & $\begin{array}{r}24 \\
148 \\
13 \\
737 \\
269\end{array}$ & $\begin{array}{r}22 \\
127 \\
12 \\
695 \\
231\end{array}$ & $\begin{array}{r}206 \\
1,349 \\
67 \\
2,900 \\
1,122\end{array}$ & $\begin{array}{r}201 \\
1,036 \\
45 \\
1,453 \\
539\end{array}$ & $\begin{array}{r}890 \\
3,126 \\
337 \\
4,286 \\
1,721\end{array}$ & $\begin{array}{r}32 \\
541 \\
18 \\
1,096 \\
240\end{array}$ & $\begin{array}{c}32 \\
121 \\
8.1 \\
179 \\
72\end{array}$ & $\begin{array}{r}- \\
\overline{10} \\
538 \\
\mathbf{4 4 4}\end{array}$ \\
\hline $\begin{array}{l}05 / 29 / 84 \\
05 / 30 / 84 \\
06 / 17 / 84 \\
06 / 18 / 84 \\
06 / 20 / 84\end{array}$ & $\begin{array}{l}85 \\
46 \\
6.6 \\
20 \\
12\end{array}$ & $\begin{array}{r}1,873 \\
1,814 \\
- \\
517 \\
-\end{array}$ & $\begin{array}{r}1,483 \\
1,502 \\
- \\
- \\
-\end{array}$ & $\begin{array}{r}336 \\
81 \\
- \\
55 \\
-\end{array}$ & $\begin{array}{r}240 \\
62 \\
- \\
- \\
-\end{array}$ & $\begin{array}{r}2,190 \\
409 \\
-\overline{-} \\
602\end{array}$ & $\begin{array}{r}776 \\
328 \\
- \\
- \\
-\end{array}$ & $\begin{array}{r}4,063 \\
2,223 \\
\overline{1,119} \\
-\end{array}$ & $\begin{array}{r}840 \\
116 \\
\overline{165} \\
-\end{array}$ & $\begin{array}{r}177 \\
52 \\
- \\
- \\
-\end{array}$ & $\begin{array}{c}890 \\
18 \\
2.1 \\
36 \\
13\end{array}$ \\
\hline $\begin{array}{l}07 / 01 / 84 \\
07 / 06 / 84 \\
07 / 07 / 84 \\
07 / 11 / 84 \\
07 / 27 / 84\end{array}$ & $\begin{array}{r}97 \\
30 \\
165 \\
87 \\
12\end{array}$ & $\begin{array}{r}2,321 \\
595 \\
2,203 \\
1,265 \\
434\end{array}$ & $\begin{array}{r}5 \overline{-} \\
2,014 \\
1,150 \\
-\end{array}$ & $\begin{array}{r}142 \\
60 \\
160 \\
91 \\
23\end{array}$ & $\begin{array}{r}\overline{45} \\
160 \\
68 \\
-\end{array}$ & $\begin{array}{r}1,674 \\
283 \\
1,621 \\
911 \\
178\end{array}$ & $\begin{array}{r}\overrightarrow{45} \\
203 \\
482 \\
-\end{array}$ & $\begin{array}{r}3,995 \\
878 \\
3,824 \\
2,176 \\
612\end{array}$ & $\begin{array}{r}963 \\
353 \\
991 \\
565 \\
38\end{array}$ & $\begin{array}{r}-\overline{74} \\
369 \\
167 \\
-\end{array}$ & $\begin{array}{r}750 \\
237 \\
1,350 \\
654 \\
-\end{array}$ \\
\hline $\begin{array}{l}11 / 28 / 84 \\
11 / 29 / 84 \\
02 / 12 / 85 \\
05 / 03 / 85 \\
05 / 21 / 85\end{array}$ & $\begin{array}{c}6.2 \\
31 \\
150 \\
23 \\
48\end{array}$ & $\begin{array}{r}130 \\
671 \\
1,119 \\
635 \\
1,364\end{array}$ & $\begin{array}{r}120 \\
613 \\
1,045 \\
590 \\
-\end{array}$ & $\begin{array}{r}19 \\
142 \\
1,377 \\
82 \\
-\end{array}$ & $\begin{array}{r}17 \\
118 \\
1,321 \\
75 \\
-\end{array}$ & $\begin{array}{r}247 \\
872 \\
6,543 \\
502 \\
3,130\end{array}$ & $\begin{array}{r}95 \\
528 \\
4,524 \\
358 \\
-\end{array}$ & $\begin{array}{r}377 \\
1,543 \\
7,662 \\
1,137 \\
4,494\end{array}$ & $\begin{array}{r}129 \\
424 \\
1,477 \\
157 \\
2,891\end{array}$ & $\begin{array}{r}23 \\
187 \\
887 \\
69 \\
-\end{array}$ & $\begin{array}{r}- \\
65 \\
785 \\
37 \\
1,770\end{array}$ \\
\hline $\begin{array}{l}06 / 16 / 85 \\
07 / 25 / 85 \\
07 / 26 / 85 \\
07 / 27 / 85 \\
07 / 31 / 85\end{array}$ & $\begin{array}{l}8.3 \\
4.5 \\
6.3 \\
9.7 \\
3.2\end{array}$ & $\begin{array}{r}184 \\
50 \\
73 \\
81 \\
-\end{array}$ & $\begin{array}{l}\overline{41} \\
- \\
- \\
-\end{array}$ & $\begin{array}{l}-\overline{21} \\
37 \\
40 \\
-\end{array}$ & $\begin{array}{l}\overline{19} \\
- \\
- \\
-\end{array}$ & $\begin{array}{r}172 \\
139 \\
211 \\
228 \\
-\end{array}$ & $\begin{array}{r}\overline{113} \\
- \\
- \\
-\end{array}$ & $\begin{array}{r}356 \\
189 \\
284 \\
309 \\
-\end{array}$ & $\begin{array}{l}66 \\
48 \\
55 \\
89 \\
-\end{array}$ & $\begin{array}{l}\overline{-} \\
\overline{-} \\
\overline{-}\end{array}$ & $\begin{array}{l}-\overline{16} \\
5.9 \\
9.8 \\
1.8\end{array}$ \\
\hline $\begin{array}{l}08 / 07 / 85 \\
08 / 08 / 85 \\
09 / 27 / 85 \\
09 / 28 / 85 \\
11 / 05 / 85\end{array}$ & $\begin{array}{c}6.1 \\
13 \\
159 \\
8.9 \\
6.3\end{array}$ & $\begin{array}{r}49 \\
132 \\
2,170 \\
423 \\
191\end{array}$ & $\begin{array}{r}\overline{-} \\
1,516 \\
423 \\
182\end{array}$ & $\begin{array}{r}16 \\
41 \\
469 \\
14 \\
53\end{array}$ & $\begin{array}{r}- \\
\overline{-} \\
367 \\
14 \\
53\end{array}$ & $\begin{array}{r}256 \\
238 \\
4,010 \\
89 \\
213\end{array}$ & $\begin{array}{r}\overline{-} \\
1,840 \\
75 \\
173\end{array}$ & $\begin{array}{r}305 \\
370 \\
6,180 \\
512 \\
404\end{array}$ & $\begin{array}{r}58 \\
124 \\
2,687 \\
21 \\
80\end{array}$ & $\begin{array}{r}- \\
\overline{-} \\
1,318 \\
16 \\
39\end{array}$ & $\begin{array}{c}39 \\
22 \\
862 \\
1.7 \\
-\end{array}$ \\
\hline $\begin{array}{l}11 / 16 / 85 \\
11 / 17 / 85 \\
11 / 28 / 85 \\
11 / 29 / 85 \\
11 / 30 / 85\end{array}$ & $\begin{array}{l}7.9 \\
11 \\
33 \\
23 \\
53\end{array}$ & $\begin{array}{r}198 \\
348 \\
- \\
\overline{-} \\
1,582\end{array}$ & $\begin{array}{l}- \\
z \\
-\end{array}$ & $\begin{array}{l}29 \\
45 \\
- \\
- \\
62\end{array}$ & $\begin{array}{l}- \\
- \\
- \\
-\end{array}$ & $\begin{array}{r}179 \\
177 \\
- \\
- \\
1,029\end{array}$ & $\begin{array}{l}z \\
z \\
z\end{array}$ & $\begin{array}{r}377 \\
525 \\
- \\
- \\
2,611\end{array}$ & $\begin{array}{r}95 \\
115 \\
- \\
- \\
797\end{array}$ & $\begin{array}{l}- \\
\overline{-} \\
- \\
-\end{array}$ & $\begin{array}{l}8.2 \\
4.6 \\
23 \\
17 \\
216\end{array}$ \\
\hline $\begin{array}{l}02 / 05 / 86 \\
02 / 18 / 86 \\
02 / 19 / 86 \\
02 / 20 / 86 \\
03 / 14 / 86 \\
03 / 15 / 86\end{array}$ & $\begin{array}{l}28 \\
42 \\
52 \\
44 \\
20 \\
32\end{array}$ & $\begin{array}{r}869 \\
1,161 \\
1,562 \\
1,745 \\
816 \\
1,234 \\
\end{array}$ & $\begin{array}{r}- \\
1,117 \\
1,520 \\
1,675 \\
806 \\
1,088 \\
\end{array}$ & $\begin{array}{r}114 \\
247 \\
272 \\
148 \\
77 \\
96 \\
\end{array}$ & $\begin{array}{r}-\overline{2} \\
254 \\
143 \\
77 \\
96 \\
\end{array}$ & $\begin{array}{r}477 \\
912 \\
1,107 \\
575 \\
525 \\
659 \\
\end{array}$ & $\begin{array}{l}52 \overline{8} \\
688 \\
334 \\
268 \\
405 \\
\end{array}$ & $\begin{array}{l}1,346 \\
2,073 \\
2,669 \\
2,320 \\
1,341 \\
1,893 \\
\end{array}$ & $\begin{array}{l}205 \\
304 \\
340 \\
170 \\
163 \\
169 \\
\end{array}$ & $\begin{array}{r}\overline{96} \\
171 \\
107 \\
61 \\
113 \\
\end{array}$ & $\begin{array}{l}54 \\
90 \\
72 \\
23 \\
63 \\
40 \\
\end{array}$ \\
\hline Total & & 32,525 & 21,857 & 5,540 & 4,429 & 36,002 & 15,037 & 68,527 & 16,622 & 4,269 & 9,152 \\
\hline
\end{tabular}



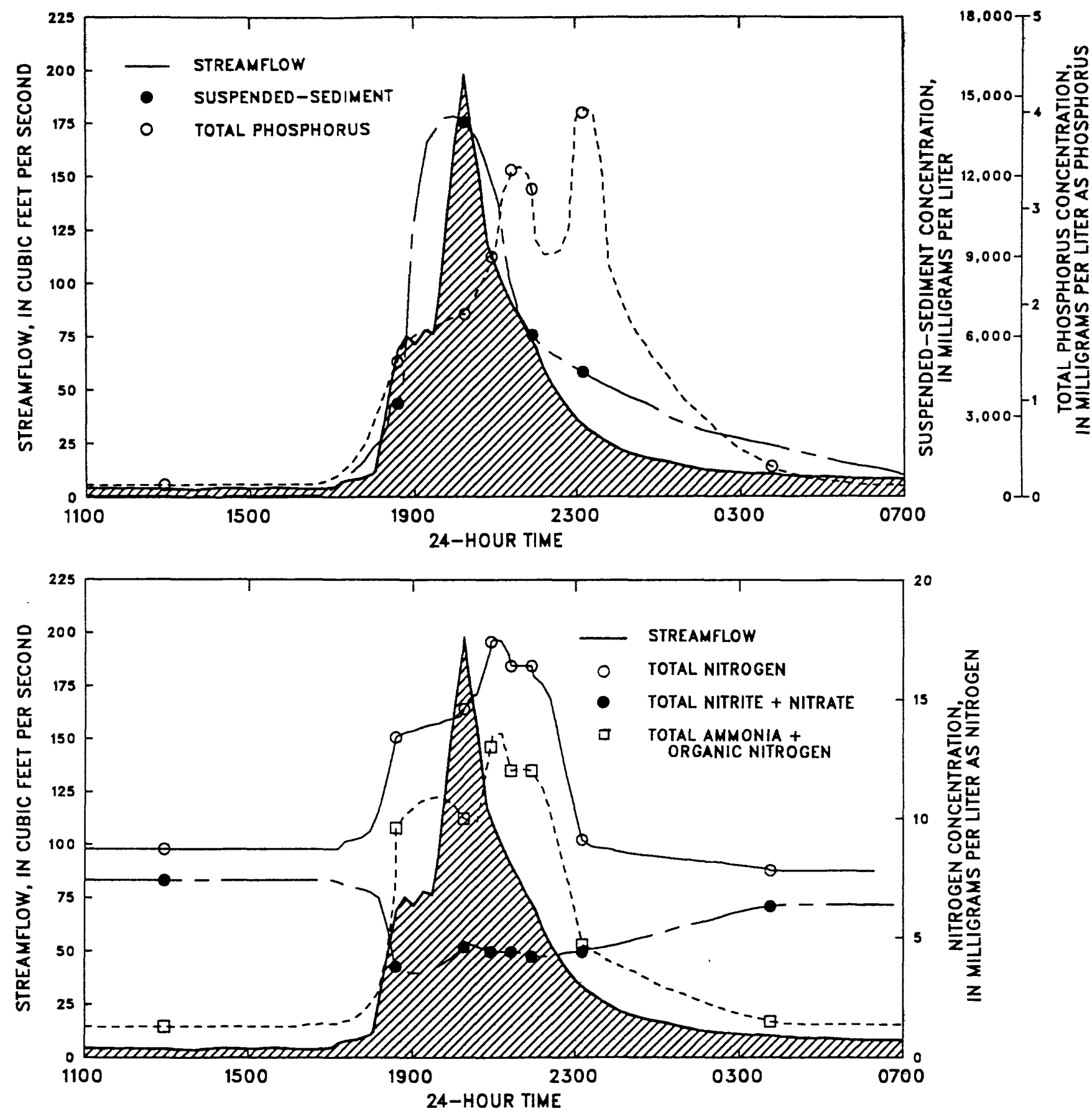

Figure 21.--Streamflow and concentrations of suspended sediment, total-nitrogen constituents, and total phosphorus at the Small Watershed during the storm of May 26-27, 1984. 


\section{Periodic Discharges}

A reconnaissance of the Nutrient-Management Subbasin and results of analyses of base-flow samples collected during the pre-BMP phase showed that nutrient-rich discharges occur periodically in the Nutrient-Management Subbasin. These discharges may come from tile drains, barn-yard runoff from cleaning manure storage pits, or from milk-house waste.

In the study area, tile drains have been installed to increase the productivity of low lying areas where surface runoff accumulates, and to divert water away from agricultural structures including barns and manure storage facilities. The water quality of the discharges from the tile drains is influenced by associated land-use practices, whereas the quantity depends on the amount of water in the soil. Four tile drains that discharge directly to the streams were located in the Nutrient-Management Subbasin. One of the tile drains, located at farm D (fig. 3), was installed to intercept subsurface flow that migrates from cropland towards an earthen animal-waste storage facility and a chicken and hog barn.

Barn-yard runoff, which may have been produced by the cleaning of manure-storage pits, can have a significant effect on the water quality in the Nutrient-Management Subbasin. Discharges from barn yards were observed on several occasions when base-flow samples were being collected.

Data in table 17 reflect the water quality of base flow in the Small Watershed when periodic discharges were being released and were characterized by discoloration of the water and a pungent odor. Elevated concentrations of ammonia plus organic nitrogen and phosphorus were measured when these discharges occurred in the Small Watershed. The solids from these discharges were deposited on the stream bottom. When ground water enters the stream through the fractured limestone streambed, the solids can be resuspended and redissolved, and the nutrient concentrations may not be representative of the ground water from the carbonate formation underlying the surface.

Table 17.-Nutrient concentrations in base flow in the Small Watershed during times of periodic point-source discharges, October 24, 1984, through March 13, 1986

[Streamflow, in cubic feet per second; concentration, in milligrams per liter; --, sample not analyzed for indicated constituent]

\begin{tabular}{|c|c|c|c|c|c|c|c|c|c|c|c|c|}
\hline Site & Date & $\begin{array}{l}\text { Stream- } \\
\text { flow }\end{array}$ & $\begin{array}{c}\text { Total } \\
\text { nitrite } \\
\text { nitrogen }\end{array}$ & $\begin{array}{c}\text { Dissolved } \\
\text { nitrite } \\
\text { nitrogen }\end{array}$ & $\begin{array}{c}\text { Total } \\
\text { nitrite } \\
\text { plus } \\
\text { nitrate } \\
\text { nitrogen }\end{array}$ & $\begin{array}{l}\text { Dissolved } \\
\text { nitrite } \\
\text { plus } \\
\text { nitrate } \\
\text { nitrogen }\end{array}$ & $\begin{array}{c}\text { Total } \\
\text { ammonia } \\
\text { nitrogen }\end{array}$ & $\begin{array}{l}\text { Dissolved } \\
\text { ammonia } \\
\text { nitrogen }\end{array}$ & $\begin{array}{c}\text { Total } \\
\text { ammonia } \\
\text { plus } \\
\text { organic } \\
\text { nitrogen }\end{array}$ & $\begin{array}{c}\text { Dissolved } \\
\text { ammonia } \\
\text { plus } \\
\text { organic } \\
\text { nitrogen }\end{array}$ & $\begin{array}{l}\text { Total } \\
\text { phos- } \\
\text { phorus }\end{array}$ & $\begin{array}{c}\text { Dissolved } \\
\text { phos- } \\
\text { phorus }\end{array}$ \\
\hline $3 A$ & $10 / 24 / 84$ & 0.30 & 0.37 & - & 6.5 & - & 0.26 & - & 2.8 & - & 0.52 & - \\
\hline 3A & $08 / 26 / 85$ & .35 & .68 & - & 5.3 & - & .57 & - & 2.2 & - & .68 & - \\
\hline 5 & $08 / 26 / 85$ & 23 & 29 & - & 3.3 & - & .53 & - & 4.4 & - & .97 & - \\
\hline $3-3 A^{1}$ & $03 / 13 / 86$ & - & .06 & .04 & 7.0 & 7.0 & 5.2 & 5.2 & 13 & $n$ & 1.6 & 1.4 \\
\hline $3 A$ & $03 / 13 / 86$ & 1.3 & .06 & .04 & 8.1 & 8.1 & 4.4 & 4.4 & 12 & 10 & 1.9 & 1.8 \\
\hline
\end{tabular}

1 3-3A Sample collected immediately downstream from drainage ditch discharging from farm G. 


\section{Ground Water}

Ground water was sampled from six wells and two springs (fig. 2) about three times per year in the Nutrient-Management Subbasin to determine general ground-water quality. The data from these wells and springs represent very local conditions, so they cannot be used to determine the effects of nutrient management at specific farms; however, the data may be helpful in showing general trends in the subbasin. The ground water at each of the sites is used for domestic and agricultural purposes. Because the wells are used in conjunction with automatic waterers for livestock, water levels in the wells fluctuate rapidly, and static water levels could not be measured at the time that water-quality samples were collected.

Table 18 and figure 22 indicate dissolved-nitrate concentrations in ground water were greater and varied more in the intensively farmed carbonate-rock floored valley than in the sandstone and shale area where slopes are steeper. The maximum dissolved-nitrate nitrogen concentrations were measured at well $\mathrm{LN} 1663$ in the valley. Although dissolved-nitrate nitrogen concentrations at $\mathrm{LN} 1663$ ranged from 25 to $15 \mathrm{mg} / \mathrm{L}$, no trend was apparent during the pre-BMP phase. The decrease in dissolved-nitrate nitrogen concentration at LN 1586 in March 1986 (fig. 22) is attributed to a long period of operation of the farmer's diesel pump that improved evacuation of the well casing when the sample was collected. Therefore, the dissolved-nitrate nitrogen concentration measured in March 1986 was probably from a more representive ground-water sample than those collected earlier at LN 1586. Nitrate-nitrogen concentrations in all samples collected from LN SP59, LN 1663, and LN 1678 exceeded the USEPA 10-mg/L nitrate nitrogen maximum contaminant level (MCL) for safe drinking water (U.S. Environmental Protection Agency, 1989). Dissolved-nitrate nitrogen concentrations changed relatively little at LN 1665, LN 1662, and LN 1666, all of which are representative of ground water in the sandstone and shale region rather than the carbonate-rock floored valley. No seasonal trends were apparent.

Ground water in the Nutrient-Management Subbasin has relatively low and constant phosphorus concentrations. Dissolved-phosphorus concentrations at all of the ground-water sites ranged from less than 0.02 to $0.07 \mathrm{mg} / \mathrm{L}$, indicating that little phosphorus leaches through the soils to the ground water.

Table 18.-Summary statistics of ground-water quality for the Nutrient-Management Subbasin

[Specific conductance, in microsiemens per centimeter; concentration, in milligrams per liter; n, number of values; <, less than]

\begin{tabular}{|c|c|c|c|c|c|c|c|c|c|}
\hline \multirow{3}{*}{$\begin{array}{l}\text { Character- } \\
\text { istic or } \\
\text { constituent }\end{array}$} & \multirow[b]{3}{*}{ Statistic } & \multicolumn{8}{|c|}{ Well or spring } \\
\hline & & \multicolumn{4}{|c|}{ Carbonate valley } & \multicolumn{4}{|c|}{ Sandstone and shale area } \\
\hline & & LNSP59 & LN1586 & LN1663 & LN1678 & LNSP60 & LN 1662 & LN 1665 & LN1666 \\
\hline $\begin{array}{l}\text { Specific } \\
\text { conductance }\end{array}$ & $\begin{array}{l}\text { Median } \\
\text { n } \\
\text { Minimum } \\
\text { Maximum }\end{array}$ & $\begin{array}{r}603 \\
7 \\
570 \\
730\end{array}$ & $\begin{array}{r}645 \\
7 \\
555 \\
775\end{array}$ & $\begin{array}{r}705 \\
7 \\
595 \\
735\end{array}$ & $\begin{array}{r}680 \\
3 \\
672 \\
795\end{array}$ & $\begin{array}{r}162 \\
4 \\
159 \\
185\end{array}$ & $\begin{array}{r}445 \\
7 \\
417 \\
532\end{array}$ & $\begin{array}{r}400 \\
7 \\
382 \\
497\end{array}$ & $\begin{array}{r}594 \\
6 \\
385 \\
785\end{array}$ \\
\hline $\begin{array}{l}\text { Nitrate, } \\
\text { dissolved } \\
\text { as } \mathrm{N}\end{array}$ & $\begin{array}{l}\text { Median } \\
\text { n } \\
\text { Minimum } \\
\text { Maximum }\end{array}$ & $\begin{array}{c}14 \\
7 \\
13 \\
16\end{array}$ & $\begin{array}{c}6.7 \\
7 \\
1.1 \\
9.0\end{array}$ & $\begin{array}{r}24 \\
7 \\
15 \\
25\end{array}$ & $\begin{array}{r}15 \\
3 \\
14 \\
15\end{array}$ & $\begin{array}{l}6.9 \\
4 \\
6.8 \\
8.8\end{array}$ & $\begin{array}{l}.42 \\
.29 \\
.99\end{array}$ & $\begin{array}{l}1.6 \\
7 \\
.69 \\
1.8\end{array}$ & $\begin{array}{l}.17 \\
6 \\
.08 \\
3.6\end{array}$ \\
\hline $\begin{array}{l}\text { Ammonia, } \\
\text { dissolved } \\
\text { as } \mathrm{N}\end{array}$ & $\begin{array}{l}\text { Median } \\
\text { n } \\
\text { Minimum } \\
\text { Maximum }\end{array}$ & $\begin{array}{c}.02 \\
7 \\
<.02 \\
.11\end{array}$ & \begin{tabular}{l}
.02 \\
\multicolumn{1}{c}{7} \\
$<.02$ \\
.04
\end{tabular} & $\begin{array}{l}.02 \\
7 \\
<.02 \\
.05\end{array}$ & $\begin{array}{c}.02 \\
3 \\
<.02 \\
.02\end{array}$ & $\begin{array}{l}.02 \\
4 \\
<.02 \\
.02\end{array}$ & \begin{tabular}{l}
.02 \\
\multicolumn{1}{l}{7} \\
$<.02$ \\
.04
\end{tabular} & \begin{tabular}{c}
.01 \\
\multicolumn{7}{c}{.01} \\
$<.02$ \\
.04
\end{tabular} & $\begin{array}{l}.02 \\
6 \\
<.02 \\
.03\end{array}$ \\
\hline $\begin{array}{l}\text { Ammonia + } \\
\text { organic } \\
\text { nitrogen, } \\
\text { dissolved } \\
\text { as } \mathrm{N}\end{array}$ & $\begin{array}{l}\text { Median } \\
\text { n } \\
\text { Minimum } \\
\text { Maximum }\end{array}$ & $\begin{array}{l}.42 \\
7 \\
.20 \\
1.3\end{array}$ & $\begin{array}{l}.30 \\
7 \\
<.20 \\
.40\end{array}$ & $\begin{array}{l}.36 \\
7 \\
<.20 \\
.60\end{array}$ & $\begin{array}{l}.30 \\
3 \\
<.20 \\
.64\end{array}$ & $\begin{array}{l}.30 \\
4 \\
26 \\
50\end{array}$ & $\begin{array}{l}.28 \\
7 \\
<.20 \\
.52\end{array}$ & $\begin{array}{c}.30 \\
7 \\
<.20 \\
.52\end{array}$ & $\begin{array}{c}.26 \\
6 \\
<.20 \\
.42\end{array}$ \\
\hline $\begin{array}{l}\text { Phosphorus, } \\
\text { dissolved } \\
\text { as } \mathbf{P}\end{array}$ & $\begin{array}{l}\text { Median } \\
\mathrm{n} \\
\text { Minimum } \\
\text { Maximum }\end{array}$ & $\begin{array}{l}.02 \\
7 \\
<.02 \\
.06\end{array}$ & $\begin{array}{l}.03 \\
7 \\
<.02 \\
.05\end{array}$ & $\begin{array}{l}.03 \\
7 \\
.03 \\
.07\end{array}$ & $\begin{array}{l}.03 \\
3 \\
.03 \\
.06\end{array}$ & $\begin{array}{c}.01 \\
4 \\
<.02 \\
.02\end{array}$ & $\begin{array}{l}.02 \\
7 \\
<.02 \\
.05\end{array}$ & $\begin{array}{l}.03 \\
7 \\
<.02 \\
.06\end{array}$ & $\begin{array}{l}.02 \\
6 \\
<.02 \\
.05\end{array}$ \\
\hline
\end{tabular}



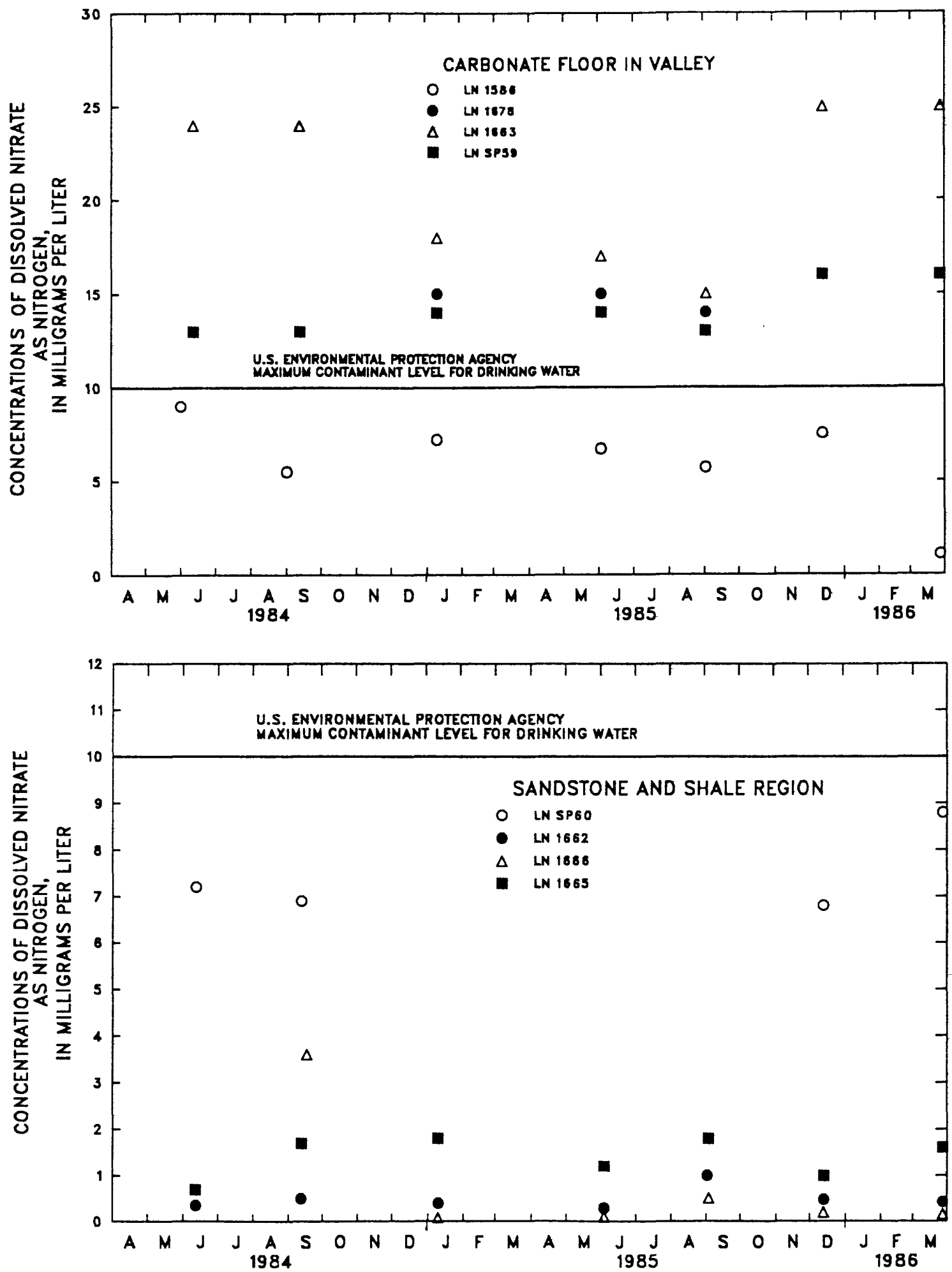

Figure 22.--Dissolved-nitrate as nitrogen concentrations in ground water in the Nutrient-Management Subbasin, April 1, 1984, through March 31, 1986. 


\section{ESTIMATES OF REDUCTIONS IN AGRICULTURAL CONTAMINANTS REQUIRED FOR OBSERVING A STATISTICALLY-SIGNIFICANT CHANGE IN WATER QUALITY}

The executive summary of the Conestoga River Headwaters RCWP 1982 Plan of Work (U.S. Department of Agriculture, 1982, p. 1) stated that the first objective of the RCWP is "to significantly reduce agricultural pollutants: nitrogen, phosphorus, pesticides, sediment, and other pollutants, entering public and private waters of the Conestoga Headwaters Watershed." More specific objectives (page 13) included the goal to "reduce nitrates and phosphates in solutions from entering receiving streams and lakes by applying the fertilizer management (nutrient management) BMP on 3,600 acres." The achievement of these objectives was felt to be instrumental in meeting the other objectives, including improving the potable quality of water and the aquatic environment within and downstream from the Conestoga Headwaters Watershed.

There are several difficulties in achieving the objectives. Estimates were made of reductions in nutrient concentrations and loads in base flow that could be measured statistically, inasmuch as the Plan of Work did not specify numerical instream nutrient reductions. In order to accomplish this, the background levels and pre-BMP trends need to be determined. Second, an investigation into the relation between statistical changes and environmental changes needs to be made. Extensive hydrologic data collection is required to develop these relations.

Other investigators, like Richards (1985), have used the Student t-test (two-sample, one-tailed) in reverse to establish target goals. Richards, in a study of phosphorus loads in the Sandusky River basin, found that, given available data and conventional statistical techniques, the probability of observing a statistically-significant reduction in phosphorus loads was only 95 percent if the true reduction were 35.6 percent. Richards said he used the $t$-test because it was a technique familiar to most workers and was readily adaptable to the problem of estimating the needed reduction. However, he acknowledged, as suggested by Hirsch and others (1982), Helsel (1987), and the National Water Quality Evaluation Project (1988), that nonparametric techniques would be more appropriate and may be more powerful than parametric techniques for analyzing water-quality data, primarily because most of the hydrologic data are non-normal (usually positively skewed). No attempt was made by Richards to determine the relation between changes that were statistically measurable and improvements in potable water or aquatic environments.

The estimated probability of observing a statistically-significant reduction in nitrogen and phosphorus loads, as a function of the true reduction in the loads, are listed in table 19. These estimates were obtained by using the means and standard deviations of the raw data for the two seasons as input to the Monte Carlo simulation of the nonparametric Seasonal rank-sum test. The procedure used to calculate these reductions is discussed on page 12 . Standard deviations for data that were log normal are listed as a positive and negative percent rather than the standard deviations of the raw data.

Figures 23 and 24 show the results of estimating the amount of reduction required for statistically measurable changes, and the power of the Seasonal rank-sum test, (1-B), which represents the probability of rejecting the null hypothesis when, in fact, it is false and the alternative hypothesis is true. The null hypothesis was that there was no difference in the mean of the pre-BMP and post-BMP data. Therefore, the power of the test gives the probability of detecting a statistically measurable change during a 2-year postBMP phase, if the data are reduced by the indicated percentage.

Although the water quality at Site 1 will likely not be affected by nutrient management, estimated reductions were calculated for this site to show differences between agricultural and nonagricultural areas prior to the implementation of a management plan. Site 1 requires the least reduction in nutrient concentrations and loads in base flow (table 19 and figures 23-24) because of the narrow range and little scatter in the data for this site. The range and scatter in the data for Site 1 are typical of other small forested and undisturbed watersheds in the Lower Susquehanna River basin (Lietman, Ward, and Behrendt, 1983) where the effects of human activities are minimal, and the geology and topography permit rapid transport of ground water through subsurface soils with little leaching before it is released as base flow. The 
requirements for measurable changes increase downstream at Sites $2 \mathrm{~A}, 3 \mathrm{~A}, 9$, and 5 where the influence by agricultural activities increase. The results suggest that, although significant reductions in concentrations and loads can occur at an upstream site, reductions may have little effect farther downstream unless nutrient management is implemented on a regional basis. For example, a reduction of 63 percent or $16 \mathrm{lb}$ less than the mean total-nitrogen load in base flow is required at Site $3 \mathrm{~A}$ to be statistically significant. However, this reduction is less than one quarter of the 69 -percent or 95 -lb reduction required downstream at Site 5.

Although the reductions required in the base flow loads appear large (table 19 and figs. 23-24), the reductions are relatively small if compared with the nutrient applications. For example, the total-nitrogen load in base flow at Site $3 \mathrm{~A}$ needs to be reduced by 63 percent to observe a statistically-significant reduction (table 19). This reduction represents $20,147 \mathrm{lb}$ of the $31,980 \mathrm{lb}$ of total-nitrogen (table 13) discharged during the 2 years as compared to the $337,610 \mathrm{lb}$ of nitrogen that were applied to the soil from the spreading of manure, commercial fertilizer, and the grazing of animals during the same period. It also should be stressed that, because the implementation of nutrient management is not expected to alter streamflows or velocities, reductions in loads can only be achieved by reducing the nutrient concentrations in the stream. 

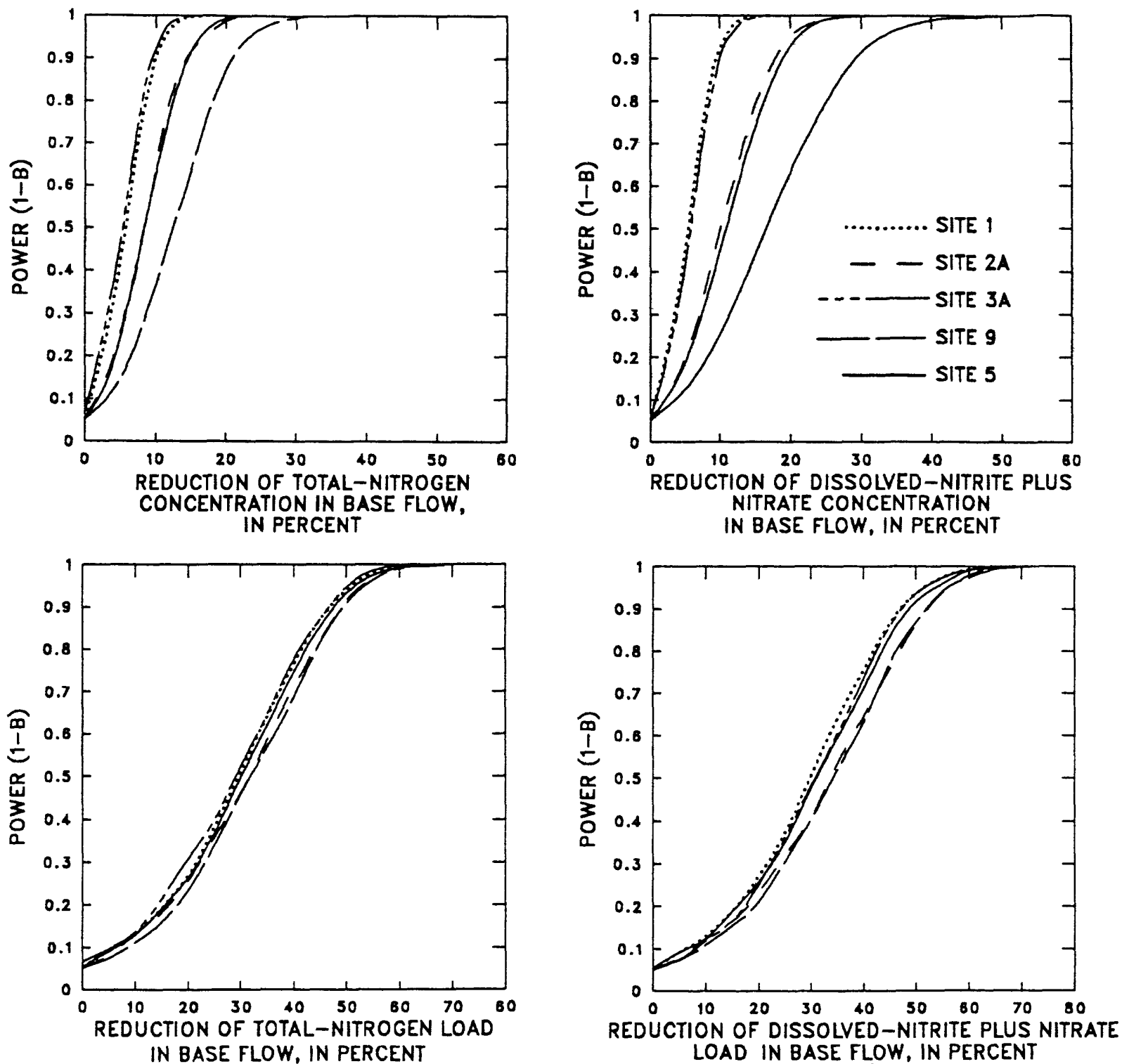

Figure 23.--Probability of achieving statistically-significant changes at selected reductions in total-nitrogen and dissolved-nitrite plus nitrate as nitrogen concentrations and loads in base flow. 

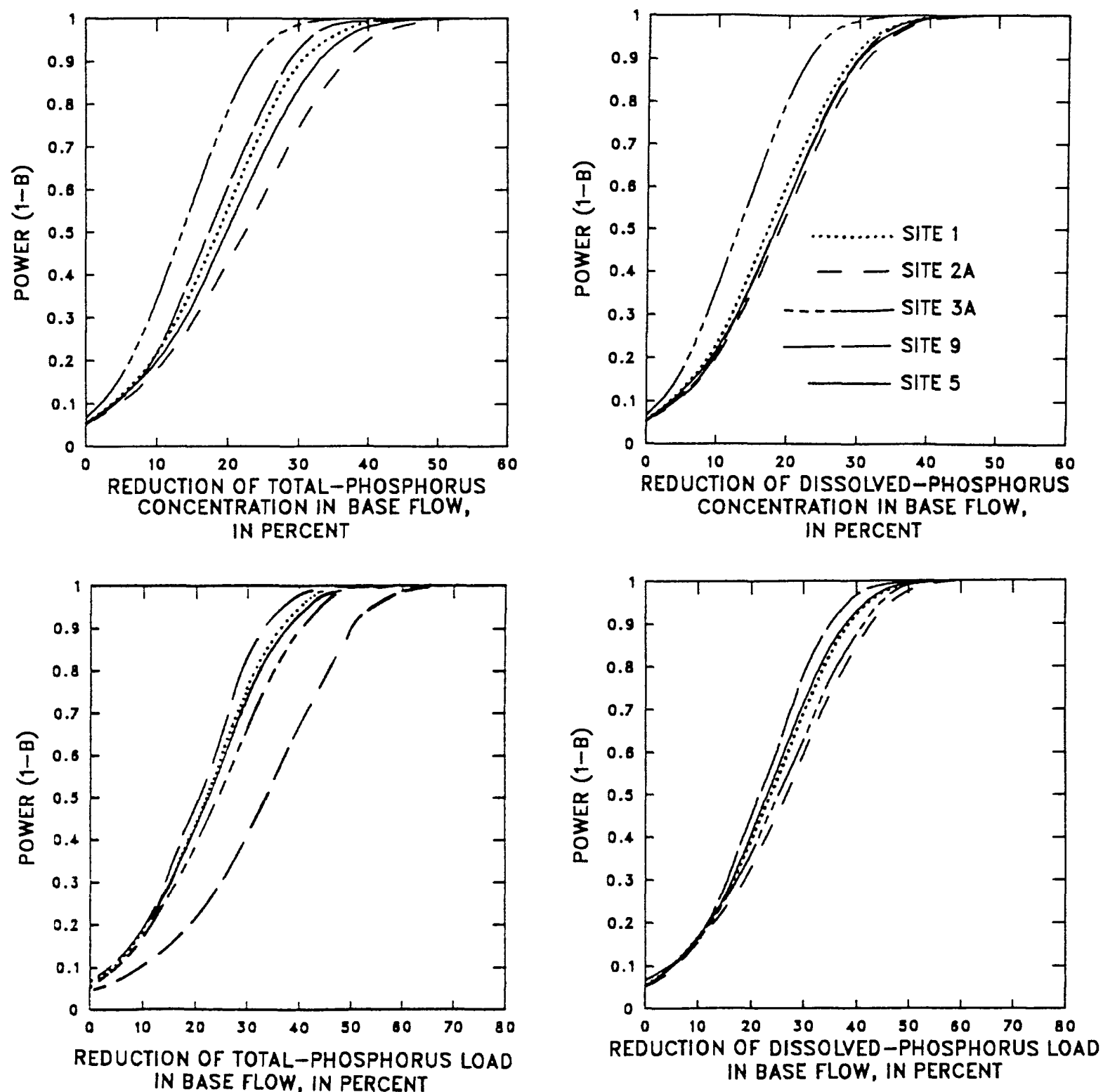

Figure 24.--Probability of achieving statistically-significant changes at selected reductions in total- and dissolved-phosphorus concentrations and loads in base flow. 
Table 19.-Water-quality characteristics of base flow during the study period, nongrowing seasons, and growing seasons, and estimated reductions in agricultural contaminants required for observing statistically-significant reductions

[concentration, in milligrams per liter (mg/L); load, in pounds (lb); estimated reductions, in percent; n, number of observations]

\begin{tabular}{|c|c|c|c|c|c|c|c|c|c|}
\hline \multirow[b]{3}{*}{ Constituent } & \multirow[b]{3}{*}{ Mean } & \multirow{3}{*}{$\begin{array}{c}\text { Study period } \\
\begin{array}{c}\text { Standard } \\
\text { deviation }\end{array} \\
\text { plus minus }\end{array}$} & \multirow{3}{*}{\multicolumn{2}{|c|}{ Mean }} & \multirow{2}{*}{\multicolumn{2}{|c|}{$\begin{array}{c}\text { Nongrowing seasons } \\
\begin{array}{l}\text { Standard } \\
\text { deviation }\end{array} \\
\end{array}$}} & \multirow{2}{*}{\multicolumn{2}{|c|}{$\begin{array}{c}\text { Growing seasons } \\
\begin{array}{l}\text { Standard } \\
\text { deviation }\end{array} \\
\end{array}$}} & \multirow{3}{*}{$\begin{array}{l}\text { Estimated } \\
\text { reductions } \\
\text { percent }\end{array}$} \\
\hline & & & & & & & & & \\
\hline & & & & & plus minus & $\mathbf{n}$ & Mean & plus minus & \\
\hline
\end{tabular}

Nitrite plus nitrate, dissolved as $\mathrm{N}$ concentration load

$2.7 \quad 15$

$3.7 \quad 124$

$13 \quad 30$

30
30

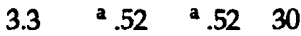

$4.4 \quad 123$ concentration load

.0560

.0786

$40 \quad 30$

$47 \quad 30$

.0476

$43 \quad 30$

.04
.05

$\begin{array}{lll}49 & 33 & 15\end{array}$

$.03 \quad 98$

.0594

Site $2 A$

Nitrite plus nitrate, dissolved as $\mathrm{N}$ concentration load

$\begin{array}{llll}3.5 & 1.1 & 1.1 & 29 \\ 6.6 & 183 & 65 & 28\end{array}$

4.2
8.1

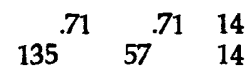

\begin{tabular}{lllll}
2.8 & \multicolumn{1}{c}{.86} & .86 & 15 \\
5.4 & 233 & 70 & 14
\end{tabular}

31

71

Nitrogen, total as $\mathrm{N}$ concentration load

$$
\begin{array}{rr}
5.7 & 47 \\
10 & 139
\end{array}
$$

$$
\begin{array}{ll}
33 & 29 \\
58 & 28
\end{array}
$$$$
5.2
$$

$\begin{array}{ll}10 & 14 \\ 53 & 14\end{array}$

.25108

$52 \quad 28$

$\begin{array}{rrrr}.18 & 44 & 30 & 14 \\ 36 & 108 & 53 & 14\end{array}$

.14115

.26148

$\begin{array}{lll}50 & 29 & .13 \\ 58 & 28 & .25\end{array}$

$\begin{array}{llllll}42 & 31 & 14 & .16 & 175 \\ 88 & 48 & 14 & & .28 & 218\end{array}$

$\begin{array}{ll}62 & 15 \\ 68 & 14\end{array}$

47

Site 3A

Nitrite plus nitrate, dissolved as $\mathbf{N}$ concentration load

22

29
29

26

$$
10
$$

$\begin{array}{rr}9 & 14 \\ 58 & 14\end{array}$

$$
\begin{array}{rr}
6.7 \quad 28 \\
22 & 159
\end{array}
$$

$21 \quad 15$

17

Nitrogen, total as $\mathrm{N}$ concentration load

$$
\begin{array}{rr}
9.0 & 22 \\
26 & 135
\end{array}
$$

$\begin{array}{lll}18 & 28 & 10 \\ 58 & 28 & 26\end{array}$

$\begin{array}{ccc}a & 85 & 2 \\ 127 & 58 & 13\end{array}$

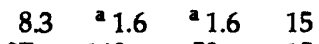

15

Phosphorus, total as $\mathrm{P}$ concentration $.18 \quad 50$

$\begin{array}{ll}.52 & 98\end{array}$

33

50

28
28

$\begin{array}{rr}.16 & 25 \\ 40 & 128\end{array}$

$19 \quad 13$

2070

.667

$\begin{array}{ll}40 & 15 \\ 41 & 15\end{array}$

Phosphorus,

dissolved as $\mathrm{P}$ concentration load

$\begin{array}{llllll}.14 & 49 & 33 & 28 & .13 & 185 \\ .40 & 98 & 50 & 28 & .33 & 115\end{array}$

$\begin{array}{ll}23 & 13 \\ 55 & 13\end{array}$

$\begin{array}{ll}.15 & 60 \\ .48 & 75\end{array}$

$\begin{array}{ll}40 & 15 \\ 44 & 15\end{array}$ 
Table 19.-Water-quality characteristics of base flow during the study period, nongrowing seasons, and growing seasons, and estimated reductions in agricultural contaminants required for observing statistically-significant reductions-Continued

[concentration, in milligrams per liter (mg/L); load, in pounds (lb); estimated reductions, in percent; $n$, number of observations]

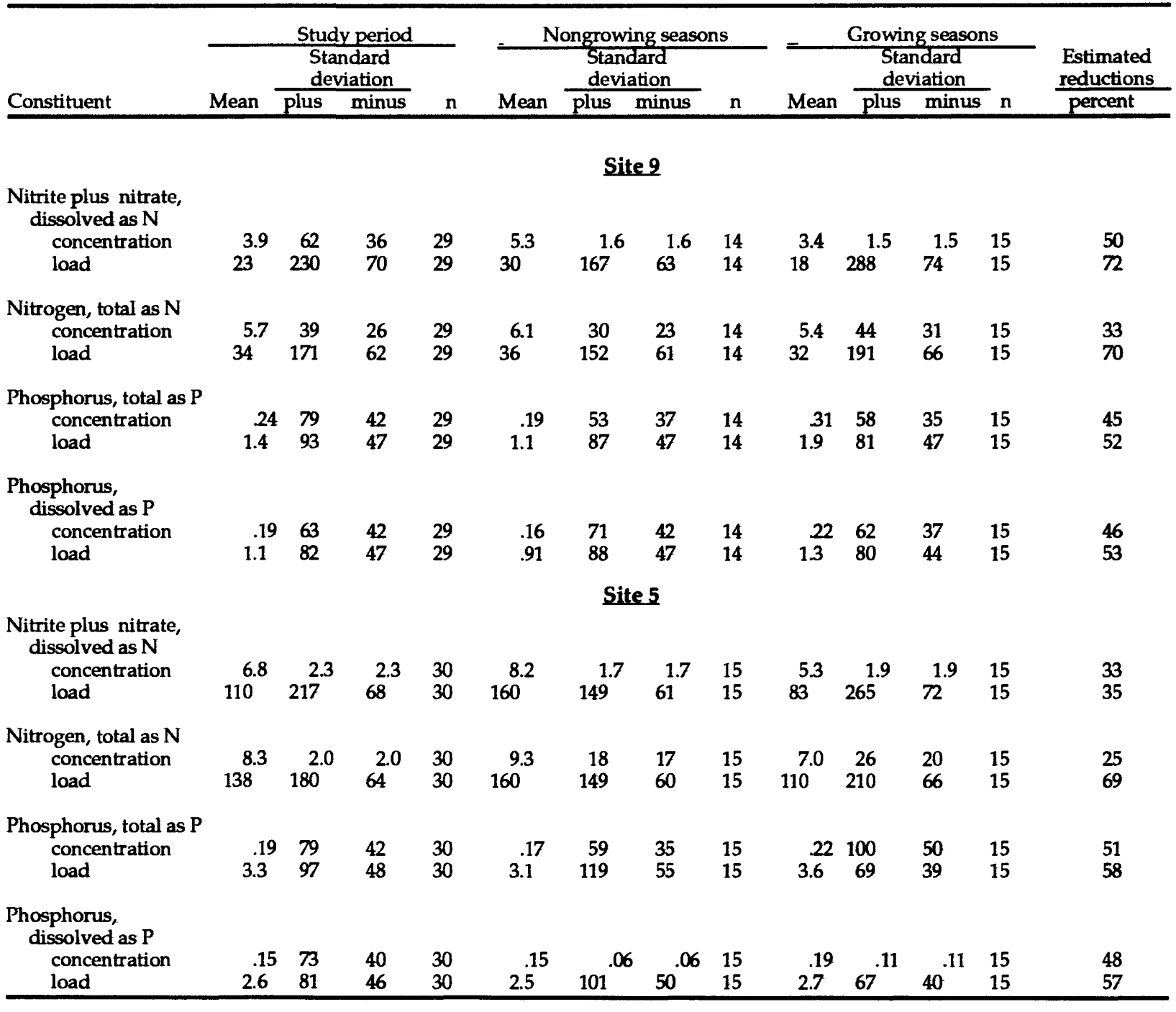

\footnotetext{
a Results for these constituents come from normally distributed data.
} 


\section{- HYPOTHETICAL EFFECTS OF REDUCTIONS IN NUTRIENT APPLICATIONS ON IMPROVEMENT IN WATER QUALITY AND EFFECT OF LAND-USE CHANGES AND RANDOM EVENTS ON WATER QUALITY}

The characterization of the Little Conestoga Creek headwaters points out the complexity of attempting to improve water quality through the implementation of nutrient management because of the variability in nutrient applications, water-quality data, land-use changes, and random events. Generally, the variability in the nutrient applications was caused by the timing of applications, which was regulated on the basis of precipitation occurrence and timing, crop requirements, and manure-storage capacities. Variability in water-quality data generally increased with the increase in size of the watershed and the increase in the area under cultivation within the watershed. Other land-use changes besides nutrient management, including random events, produce effects that add to the complexity of attempting to improve the water quality.

If the seasonal variation in applications of nitrogen and phosphorus changes, as is expected when nutrient management is implemented, then the utilization of the nutrients by crops also will change. As a result, a change would be expected to occur in the amount of nutrients available for transport to the stream in surface runoff or in ground water that is released as base flow.

\section{Improvement of Water Quality}

The effects of nutrient management on water quality in the Little Conestoga Creek head waters will depend on the total area for which plans are developed. If plans are developed at a future date for the Nonnutrient-Management Subbasin, then implementation of nutrient management will improve the chances of detecting improved water quality at Site 5 . The Paired-Watershed analyses should, with high probability, detect any substantial changes in the water quality. In particular, if the phosphorus loads decline by 56 percent at the Nutrient-Management Subbasin, given the resolution of the statistical methods employed here, the probability of detecting a significant downtrend is approximately 95 percent. Inasmuch as nutrient management will not have an effect on streamflow or stream velocities, and the amount and timing of precipitation can not be controlled, water quality will be improved by nutrient management only if nutrient concentrations in the water are reduced.

In addition to various statistical analyses, the hypothetical effects of nutrient management for each constituent need to be evaluated separately on the basis of that constituent's known chemical or physical importance to water quality. For example, if all nitrate-nitrogen concentrations during the post-BMP phase are less than the Commonwealth of Pennsylvania water-quality criterion of $10 \mathrm{mg} / \mathrm{L}$ (Pennsylvania Department of Environmental Resources, 1989), then some improvement will have been made, inasmuch as nitrate-nitrogen concentrations exceeded the $10 \mathrm{mg} / \mathrm{L}$ criterion in five samples collected at Site $3 \mathrm{~A}$ and in six samples collected at Site 5 during the pre-BMP phase. Thus, true improvement in water quality could occur even though the statistical tests indicated that the probability was very low.

As with nitrogen, specific concentrations of phosphorus have been associated with particular environmental conditions. Although the Commonwealth of Pennsylvania has no water-quality criteria for total or dissolved phosphorus in free-flowing streams, according to Mackenthum (1969) and USEPA (1986) concentrations of total phosphorus should not exceed $0.1 \mathrm{mg} / \mathrm{L}$ if nuisance growths in streams are to be prevented. The $0.01-\mathrm{mg} / \mathrm{L}$ concentration was rarely exceeded at Site 1 but was exceeded nearly 100 percent of the time at sites $2 \mathrm{~A}, 3 \mathrm{~A}, 9$, and 5 . Although table 19 indicates that reductions in mean concentrations of total phosphorus in base flow of $54,36,45$, and 51 percent are required to produce statistically measurable changes at sites $2 \mathrm{~A}, 3 \mathrm{~A}, 9$, and 5 , respectively, reductions of these magnitudes will still result in mean concentrations that exceed $0.1 \mathrm{mg} / \mathrm{L}$. Thus, it is possible to have statistically measurable changes without actually observing changes in water quality. Because no criteria have been established for nutrient discharges from nonpoint sources, the effects of reducing nitrogen and phosphorus loads on aquatic environments can not be evaluated at this time. 
Finally, this characterization has indicated that even if a change in water quality is detected within the $1.42-\mathrm{mi}^{2}$ Nutrient-Management Subbasin, the improvement may have little effect just $4.3 \mathrm{mi}$ downstream at the 5.82- $\mathrm{mi}^{2}$ Small Watershed site. It is evident that the 63-percent reduction (table 19) of the 31,980 lb of total nitrogen (table 13) discharged in base flow at Site 3A needed to detect an improvement will not be sufficient to meet the 70-percent reduction (table 19) of the $161,980 \mathrm{lb}$ (table 13) required at Site 5 to detect an improvement. Therefore, nutrient management can affect local water quality, but regional implementation is needed to affect regional water quality.

\section{Effects of Land-Use Changes}

The preceding discussion was based on the assumption that no major changes in land use or management practices other than nutrient management are implemented within the study area during the post-BMP phase. However, during the pre-BMP phase, three of the farms in the Nutrient-Management Subbasin were sold and changes in land use were planned. The division of one of the farms, Farm E (fig. 3), into building lots may affect water quality because soils will be exposed and the potential for transport of sediment and associated nutrients will increase. In 1986, plans were made to rehabilitate an old park near Farm $\mathrm{E}$ in the northeastern part of the Nutrient-Management Subbasin. Included in this park will be the construction of a small parking lot, picnic grounds, and a pond. Another farm that was sold is on the northern border of the subbasin. This farm, not identified in figure 3 because of its small contribution to the subbasin, was purchased by a private school as a site for its athletic field.

The construction of manure-storage facilities can affect soil nutrients. If open-storage facilities gain increased acceptance in the study area, the amount of nutrients from atmospheric deposition can increase. Recent studies by van Breeman and others (1982) and data collected from a small agricultural watershed in Adams County (Fishel, D.K., Truhlar, M.V., and Langland, M.J., U.S. Geological Survey, written commun., 1989 ) indicate that nitrogen concentrations in precipitation, especially ammonia, are significant near manure-storage facilities. The construction of any manure-storage facility will affect the timing of manure applications and thus alter nutrient concentrations in the soils.

Changes in cropping patterns also can affect soil nutrients. If the amount of alfalfa in the subbasin increases (as can be recommended as part of the total farm-conservation plan) then soil-nitrogen concentrations may increase. If not utilized by other crops, then the nitrogen will be available for leaching to the ground water.

\section{Effects of Random Events}

Random events that can affect nutrient management and water quality include large storms, changes in animal population or types, outbreaks of animal diseases, and other events. The effects of Hurricane Gloria have been described earlier in the report. Such random events can have substantial effects on water quality by affecting the processes of surface runoff, infiltration, recharge, crop uptake, evapotranspiration, and the timing of most farm operations. If changes occur in animal populations or types, additional manure may need to be exported (a costly procedure) or the manure will be applied to the soil. Changes in animal populations depend on the market demands, which can change suddenly. If animal diseases break out in the subbasin, restrictions can be placed on the removal of manure from the subbasin. (Avian influenza and swine pseudorabies were prevalent in the general area during the pre-BMP phase.) Other random events can have an impact on farmer cooperation. These include changes in the financial status of the agricultural community, health of the land owner, and the religious and cultural mores of the dominant Amish and Mennonite populations in the study area. 
Hydrologic and land-use data were collected in a Small Watershed study area in the Conestoga River Headwaters from April 1984 through March 1986 as part of the Rural Clean Water Program directed by the U.S. Department of Agriculture. The study was done to describe the land use and hydrology and characterize the water quality of the Small Watershed, the Nutrient-Management Subbasin, and the Nonnutrient-Management Subbasin during the 2-year pre-Best-Management Practice phase.

Overall, precipitation during the 2 years was about 10 percent below normal but was 5 percent above normal during the 1984 growing season and 11 percent above normal during the 1985 growing season. A total of $76 \mathrm{in}$. of precipitation was recorded during the 2 years.

Ninety-one percent of the land in the Nutrient-Management Subbasin is used for agriculture. Most farms are small (less than 100 acres) and are operated by the owner. Approximately 52 percent of the crop acreage in the Nutrient-Management Subbasin is planted in corn. In the Nutrient-Management Subbasin, poultry composed about half of the animal population; dairy cows and hogs composed most of the other half. The total animal population for the farms was about 1,500 animal units or an average of about 1.8 animal units per acre; a maximum of 1.5 animal units per acre is considered critical with respect to the generation of nonpoint-source discharges.

The animals produced an annual average of 18,000 tons of manure, which was estimated to contain $345,000 \mathrm{lb}$ of nitrogen and $93,000 \mathrm{lb}$ of phosphorus. About 7,190 tons of manure were applied by the farmers the first year, and 8,175 tons were applied during the second year to cropland in the Nutrient-Management Subbasin. An additional 3,900 tons was estimated to be deposited by grazing animals in pastures near the stream. Excess manure that was not spread to cropland was deposited on pastures or fields outside the Nutrient-Management Subbasin. Most farms have limited manure-storage facilities. Therefore, manure is applied to the fields whenever spreaders can get onto the fields.

Fourteen of the 16 farmers in the Nutrient-Management Subbasin applied 203,150 lb of nitrogen in the form of manure and $50,660 \mathrm{lb}$ in the form of commercial fertilizer during the 2 years (no data were available from the other two farmers). About $51,000 \mathrm{lb}$ of phosphorus in the form of manure and 13,140 lb of phosphorus in the form of commercial fertilizer were applied. About $83,800 \mathrm{lb}$ of nitrogen and $18,100 \mathrm{lb}$ of phosphorus are estimated to have been deposited by grazing animals. Another 7,120 lb of nitrogen are estimated to have been contributed from the rotation of alfalfa. During the first year, about $119,300 \mathrm{lb}$ of nitrogen were applied by the 14 farmers. During the second year, about $134,510 \mathrm{lb}$ of nitrogen were applied. Phosphorus applications increased from $28,990 \mathrm{lb}$ the first year to $35,150 \mathrm{lb}$ the second year.

Concentrations of nitrate-nitrogen in the soil ranged from 45 to $372 \mathrm{lb} / \mathrm{acre}$ in the upper $4 \mathrm{ft}$ after the growing season. Concentrations of phosphorus ranged from 1.4 to $23 \mathrm{lb} / \mathrm{acre}$.

Streamflow was nearly normal during the first year and was estimated to be 15 pencent below normal during the second year. Streamflow characteristics at Site 3A (at the mouth of the Nutrient-Management Subbasin) and Site 5 (at the mouth of the Small Watershed study area) were similar. Streamflow at both sites increased rapidly during storms. About 57 percent of the total streamflow at Site 5 during the 2 years was base flow, and 20 percent of the flow at Site 5 was from Site 3A. Annual average streamflows were 7.57 and $5.55 \mathrm{ft}^{3} / \mathrm{s}$ at Site 5, and 1.28 and $1.23 \mathrm{ft}^{3} / \mathrm{s}$ at Site $3 \mathrm{~A}$ for the periods April 1984 through March 1985 and April 1985 through March 1986, respectively. 
Nutrient concentrations in base flow increased as the stream flowed from the steep shale and sandstone areas to the carbonate floor of the valley. The maximum median total-nitrogen concentration in base flow was $9.8 \mathrm{mg} / \mathrm{L}$ at the Nutrient-Management Subbasin (Site 3A). The median total-nitrogen concentration in base flow at the most upstream site (Site 1) was $3.4 \mathrm{mg} / \mathrm{L}$ and, at the most downstream site (Site 5), was $8.0 \mathrm{mg} / \mathrm{L}$. Most of the nitrogen in base flow was dissolved nitrate. Median dissolvednitrite plus nitrate nitrogen concentrations increased from $2.7 \mathrm{mg} / \mathrm{L}$ at Site 1 to $8.1 \mathrm{mg} / \mathrm{L}$ at Site 5 . Median total-phosphorus concentrations in base flow increased from $0.05 \mathrm{mg} / \mathrm{L}$ at Site 1 to $0.20 \mathrm{mg} / \mathrm{L}$ at Site $2 \mathrm{~A}$ in the middle of the Nutrient-Management Subbasin. Maximum total-phosphorus concentrations in base flow were measured at the Nonnutrient-Management Subbasin (Site 9); the median concentration there was $0.23 \mathrm{mg} / \mathrm{L}$.

Maximum concentrations of dissolved nitrite plus nitrate nitrogen in base flow were measured during wet periods when infiltrating precipitation was in longer contact with the nutrient-rich soil.

Concentrations of dissolved-nitrite plus nitrate nitrogen increased rapidly in the fall after manure was spread on harvested fields. Decreases in dissolved-nitrite plus nitrate nitrogen concentrations during the growing season coincided with increases in nutrient utilization and evapotranspiration by crops and vegetation, and decreases in precipitation, infiltration, and subsequent recharge of the ground water. The effects of precipitation, nutrient applications, and nutrient utilization by crops on dissolved-nitrite plus nitrate nitrogen concentrations and loads may have been greater at Site $3 \mathrm{~A}$ than Site 5 , because 52 percent of the total acreage at Site $3 \mathrm{~A}$ was planted in corn, which has a high nitrogen demand. Maximum phosphorus concentrations were measured during low base flows when the length of time for interaction between sediment and ground water is the greatest.

About 290 tons of suspended sediment, 81 tons of nitrogen, and 1.45 tons of phosphorus discharged during base flow at Site 5 during pre-BMP phase. During the same period, 45 tons of suspended sediment, 16 tons of nitrogen, and 0.27 ton of phosphorus discharged during base flow from Site $3 \mathrm{~A}$.

About 9,150 tons of suspended sediment, 34 tons of nitrogen, and 8.3 tons of phosphorus discharged past Site 5 during storms while 560 tons of suspended sediment, 6.6 tons of nitrogen and 1.4 tons of phosphorus discharged past Site 3A.

The availability of nutrients for transport at the Paired-Watersheds or the factors controlling nutrient transport probably are different at the two subbasins.

Ground water in the intensively farmed carbonate-rock floored valley of the Nutrient-Management Subbasin had greater nitrate-nitrogen concentrations than did ground water in the steep sandstone and shale areas. Ground water in three wells in the valley consistently had nitrate-nitrogen concentrations that exceeded the U.S. Environmental Protection Agency maximum contaminant level of $10 \mathrm{mg} / \mathrm{L}$. The maximum nitrate-nitrogen concentration measured in a well was $25 \mathrm{mg} / \mathrm{L}$.

Discharges from an area where pesticide containers were disposed of, from tile drainage, and from farm-lot runoff periodically affect water quality in the Nutrient-Management Subbasin. The total affect of these discharges on water quality was not quantified because of their intermittent nature.

Results from a nonparametric statistical test for seasonal data indicate that substantial reductions in concentrations and loads of nitrogen and phosphorus in base flow will be needed to observe statisticallysignificant improvements in water quality. It was calculated that concentrations and loads of total nitrogen in base flow at the five sites need to be reduced by 15 to 33 percent, and by 63 to 70 percent, respectively, to be assured of detecting the changes in water quality, and concentrations and loads of total phosphorus need to be reduced by 36 to 54 percent, and by 52 to 69 percent, respectively. 
Berg, T.M. and others, 1980, Geologic map of Pennsylvania: Pennsylvania Geological Survey, Map 1, plate 1, East Half, scale 1:250,000.

Chichester, D.C., 1988, Evaluation of agricultural Best- Management Practices in the Conestoga River headwaters, Pennsylvania: Methods of data collection and analysis, and description of study areas: U.S. Geological Survey Open-File Report 88-96, 32 p.

Crawford, C.G., Slack, J.R., and Hirsch, R.M., 1983, Nonparametric tests for trends in water-quality data using the Statistical Analysis System: U.S. Geological Survey Open-File Report 83-550, 102 p.

Fishel, D.K., and Lietman, P.L., 1986, Occurrence of nitrate and herbicides in ground water in the Upper Conestoga River basin, Pennsylvania: U.S. Geological Survey Water Resources Investigations Report $85-4202,8$ p.

Hallberg, G.R., 1987, Nitrates in Iowa groundwater, in D'Itri, F.M. and Wolfson, L.G., Rural groundwater contamination: Michigan, Lewis Publishers, Inc., chap. 3, p. 23-68.

Hallberg, G.R., and others, 1984, Temporal changes in nitrates in groundwater in Northeastern Iowa, lowa Geological Survey, Open-File Report 84-1, 10 p.

Helsel, D.R., 1987, Advantages of nonparametric procedures for analysis of water-quality data, Hydrological Sciences Journal, v. 32, no. 2, p. 179-190.

Hirsch, R.M., Slack, J.R., and Smith, R.A., 1982, Techniques of trend analysis for monthly water- quality data: Water Resources Research, v. 18, p. 107-121.

Lietman, P.L., Ward, J.R., and Behrendt, T.E., 1983, Effects of specific land uses on nonpoint sources of suspended sediment, nutrients, and herbicides - Pequea Creek Basin, Pennsylvania 1979-80: U.S. Geological Survey Water-Resources Investigations Report 83-4113, 88 p.

Mackenthum, K.M., 1969, The practice of water pollution biology: Washington, D.C., Federal Water Pollution Control Administration, $281 \mathrm{p}$.

National Water Quality Evaluation Project, 1988, Rural Clean Water Program 1988 Workshop Proceedings, North Carolina State University Department of Biological and Agricultural Engineering, Raleigh, North Carolina, p. 112-113.

Noether, G.E., 1976, Introduction to Statistics - A Nonparametric Approach, Boston, Massachusetts, Houghton Mifflin Co., 292 p.

P-STAT, Inc., 1986, P-Stat: User's manual: Duxbury Press, Boston, 852 p. 


\section{REFERENCES CITED-Continued}

Pennsylvania Department of Agriculture, 1985 Crop and Livestock Annual Summary, Pennsylvania Agricultural Statistics Service, PA SS-91, $71 \mathrm{p}$.

Pennsylvania Department of Environmental Resources, Bureau of Water Quality Management, Manure management for environmental protection, Publication no. 43, 72 p.

-_-1986, Manure management for environmental protection: Field Application of manure supplement, $13 \mathrm{p}$.

-1989, Chapter 93, Water Quality Standards, as amended: Pennsylvania Bulletin, v. 19, no. 10, March 11, 1989, p. 968- 997.

Pennsylvania State University, College of Agriculture, Cooperative Extension Service, 1987, The Penn State Agronomy Guide 1987-88: 148 p.

Pettyjohn, W.A., and Henning, R., 1979, Preliminary estimate of ground-water recharge rates, related streamflow and water quality in Ohio: The Ohio State University Department of Geology and Mineralogy Project Completion Report no. 522, 323 p.

Porterfield, G., 1972, Computation of fluvial-sediment discharge: U.S. Geological Survey Techniques of Water Resources Investigations, Book 3, Chapter 3, 66 p.

Rehm, G., Zoubek, G., and Hoorman, R., 1983, Farmers tackle water quality, use new management tools: Institute of Agriculture and Natural Resources, University of Nebraska, Lincoln, Nebr., in Farm, Ranch and Home Quarterly (Fall 1983), p. 8-10.

Richards, R.P., 1985, Estimating the extent of reduction needed to statistically demonstrate reduced nonpoint phosphorus loading to Lake Erie: Journal of Great Lakes Research, v. 11, no. 2, p. 110-116.

SAS Institute, Inc., 1979, SAS users guide, 1979 edition: Gary, North Carolina, SAS Institute, Inc., 494 p.

SAS Institute, Inc., 1982a, SAS users guide - basics, 1982 edition: Gary, North Carolina, SAS Institute, Inc., $924 \mathrm{p}$.

SAS Institute, Inc., 1982b, SAS users guide - statistics, 1982 edition: Gary, North Carolina, SAS Institute, Inc., $584 \mathrm{p}$.

Schueller, J.P., 1983, An assessment of agricultural nonpoint source pollution in selected high priority watersheds in Pennsylvania: Pennsylvania Department of Environmental Resources, Bureau of Soil and Water Conservation, $48 \mathrm{p}$. 
Skougstad, M.W., and others 1979, Methods for determination of inorganic substances in water and fluvial sediments: U.S. Geological Survey Techniques of Water- Resources Investigations, Book 5, Chapter A1, $626 \mathrm{p}$.

Spooner, J., Maas, R.P., Dressing, S.A., Smolen, M.D., and Humenik, F.J., 1985. Appropriate designs for documenting water quality improvements from agricultural NPS control programs. In: Perspectives on Nonpoint Source Pollution, EPA 440/5-85-001, p. 30- 34.

U.S. Department of Agriculture, 1985, Soil Survey of Lancaster County, Pennsylvania, 152 p.

U.S. Department of Agriculture, Agricultural Stabilization and Conservation Service, 1982, Conestoga Headwaters Rural Clean Water Program 1982 Plan of Work, 61 p.

U.S. Environmental Protection Agency, 1986, Quality criteria for water, 1986: USEPA-400/5-86-001, 256 p.

-1979, Methods for Chemical Analysis of Water and Wastes: USEPA-600/4-79-020, 466 p.

-1989, National Primary and Secondary Drinking Water Regulations; Proposed Rule, Federal Register, May 22, 1989, v. 54, no. 97, p. 21931-22272.

-1983, Chesapeake Bay Program Management Report: Chesapeake Bay: A Framework for Action, $186 \mathrm{p}$.

-1985, Organochlorine Pesticides and PCBs - Method 608: Availability, Code of Federal Regulations, Special Edition of Federal Register, v. 40, pt. 136, Appendix A, p. 348-367.

U.S. Geological Survey, 1985, Water Resources data for Pennsylvania, Water Year 1984, Volume 2, Susquehanna and Potomac River Basins: U.S. Geological Survey Water-Data Report PA-84-2, 327 p.

-1987, Water resources data for Pennsylvania, Water Year 1985, Volume 2, Susquehanna and Potomac River Basins: U.S. Geological Survey Water-Data Report PA- 85-2, 361 p.

-1988, Water Resources Data for Pennsylvania, Water Year 1986, Volume 2, Susquehanna and Potomac River Basins: U.S. Geological Survey Water-Data Report PA-86-2, 330 p.

van Breemen, N., Burrough, P.A., Velthorst, E.J., van Dobben, H.F., de Wit, T., Ridder, T.B., and Reijnders, H.F.R., 1982, Soil acidification from atmospheric ammonium sulphate in forest canopy throughfall: Nature, v. 299, p. 548-550. 